\title{
STATEMENT ON SEASONAL INFLUENZA VACCINE FOR 2012-2013
}

\author{
Appendix I: New Evidence Review for Children 24 to 59 Months of Age
}

\section{Preamble}

The National Advisory Committee on Immunization (NACl) provides the Public Health Agency of Canada with ongoing and timely medical, scientific and public health advice relating to immunization. The Public Health Agency of Canada acknowledges that the advice and recommendations set out in this statement are based upon the best currently available scientific knowledge and is disseminating this document for information purposes. People administering the vaccine should also be aware of the contents of the relevant product monograph(s). NACl recommendations for use and other information set out herein may differ from that set out in the product monograph(s). Manufacturer(s) have sought approval of the vaccine(s) and provided evidence as to its safety and efficacy only when it is used in accordance with the product monographs. $\mathrm{NACl}$ members and liaison members conduct themselves within the context of the Public Health Agency of Canada's Policy on Conflict of Interest, including yearly declaration of potential conflict of interest.

NACI Members: Dr. Bryna Warshawsky (Chair), Dr. Natasha Crowcroft, Ms. Anita Hanrahan, Dr. Bonnie Henry, Dr. Shainoor Ismail (Executive Secretary), Dr. Deepali Kumar, Dr. Shelly McNeil, Dr. Caroline Quach-Thanh, Dr. Marina Salvadori, Dr. Blair Seifert, Dr. Nadine Sicard, Dr. Wendy Vaudry, Dr. Richard Warrington

Liaison Representatives: Dr. Jason Brophy (Canadian Association for Immunization Research and Evaluation), Dr. lan Gemmill (Canadian Public Health Association), Dr. Alison Mawle (U.S. Centers for Disease Control and Prevention), Dr. Dorothy Moore (Canadian Paediatric Society), Dr. Heather Morrison, (Council of Chief Medical Officers of Health), Dr. Anne Opavsky (Association of Medical Microbiology and Infectious Disease Canada), Dr. Pierre Plourde (Committee to Advise on Tropical Medicine and Travel), Dr. Shelley Rechner (College of Family Physicians of Canada), Dr. Vyta Senikas (Society of Obstetricians and Gynaecologists of Canada).

Ex-Officio Representatives: Lt.-Col. Dr. Jim Anderson (Canadian Forces Health Services Group, Department of National Defence), Dr. Agnes Klein (Biologics and Genetic Therapies Directorate, Health Canada), Dr. Barbara Law (Centre for Immunization and Respiratory Infectious Diseases, Public Health Agency of Canada), Dr. Marcus Lem (First Nations and Inuit Health Branch, Health Canada), Ms. Danielle Poulin (Centre for Immunization and Respiratory Infectious Diseases, Health Canada), Dr. Joanne Xiong (Biologics and Genetic Therapies Directorate, Health Canada).

Additional Influenza Working Group Members: Dr. Brenda Cholin, Dr. Curtis Cooper, Dr. Scott Halperin, Dr. Joanne Langley, Dr. Allison McGeer, and Dr. Paul Van Buynder. 


\section{Table of Contents}

I.1 Introduction

I.2 Burden of Disease

I.2.1 Outpatient Visits

I.2.2 Hospitalizations

1.2.3 Mortality

I.3 Efficacy and Effectiveness

1.3.1 Trivalent Inactivated Influenza Vaccines (TIV)

1.3.2 Live Attenuated Influenza Vaccines (LAIV)

1.3.3 Acute Otitis Media (AOM)

1.3.4 Indirect Protection

I.4 Immunogenicity

I.5 Safety

1.5.1 Trivalent Inactivated Influenza Vaccines (TIV)

1.5.2 Live Attenuated Influenza Vaccines (LAIV)

1.5.3 Studies Including Both Trivalent Inactivated and Live Attenuated Influenza Vaccines

I.6 Tables

List of Abbreviations

References 


\section{I.1 Introduction}

$\mathrm{NACl}$ now includes children 24 to 59 months of age among recommended recipients of seasonal influenza vaccine ( $\mathrm{NACl}$ recommendation Grade A).

Children 24 to 59 months of age are at high risk for influenza related complications, carrying a significant burden of influenza illness and influenza-associated medical attendance, hospitalization and death.

Additionally, children 24 to 59 months of age are efficient transmitters of influenza virus and their vaccination may protect high risk groups (e.g. young infants, the elderly, and the immunocompromised) who may themselves be too young to be vaccinated or may not respond well to the vaccine.

To inform this recommendation, a review of the literature was conducted for children 24-59 months of age. The literature search was conducted using the Medline and Embase databases and included the period from January 1, 2002 to November 2, 2011. Articles selected for review included studies based on trivalent inactivated and live-attentuated influenza vaccines. Articles based on studies of monovalent $2009 \mathrm{pdm} A(\mathrm{H} 1 \mathrm{~N} 1)$ vaccines were not included as part of the evidence review. Although the age range included in the studies reviewed may extend beyond the 24 to 59 month age group, studies included either had a large proportion of participants in the target age range or a sub-group analysis of participants within the target age group was undertaken.

This appendix will discuss the evidence reviewed, including the burden of disease, and influenza vaccine efficacy, effectiveness, immunogenicity, and safety.

\section{I.2 BURDEN OF DISEASE}

The burden of influenza infection, illness and complications is significant among children. ${ }^{(1)-(4)}$ Although healthy children 24 to 59 months of age are not impacted to the degree to which children $<2$ years of age are, this age group experiences influenza attributed morbidity and mortality, including significant rates of influenza attributed outpatient visits and hospitalizations. ${ }^{(1)-(6)}$

The estimated, annual influenza attack rate in children 24-59 months of age is reported in the range of $10-40 \% .^{(1)(2)}$ (7) In specific settings, the attack rate has been found to be higher. For children attending day care in the United States (US), 50\% of children were infected over the course of one influenza season. ${ }^{(7)}$ In a 25 -year prospective study of children $<5$ years of age enrolled at the Vanderbilt Vaccine Clinic in Tennessee, US, the annual laboratory confirmed influenza attack rate ranged from $15-42 \% .{ }^{(2)}$

Based on case reports from hospitals, paediatric intensive care units (PICUs) and public health departments in California during the 2003-2004 to 2005-2006 influenza seasons, Louie et al. found that of the 160 cases of laboratory confirmed influenza infections reported in those $<18$ years of age, $47 \%$ were among previously healthy children and adolescents. ${ }^{(8)}$ For the 131 cases reported among children $<5$ years of age, $52 \%$ were among previously healthy children.

In a retrospective study of children in Finland, approximately $12 \%$ of the influenza $A$ attributed hospitalizations $(n=544)$, median age 2.0 years (IQR 0.9-4.8), experienced febrile seizures. ${ }^{(9)}$ Of the total hospitalizations, $25 \%$ had an underlying medical condition. A retrospective cohort study conducted in Hong Kong in 1997-98 examined medical records of children 6 months to 5 years of age, who were hospitalized with fever, $n=144$ in 1997 (mean age 24.9 months SD 14.7) and $n=272$ in 1998 (mean age 27.7 months SD14.5). ${ }^{(10)}$ The study found that the overall incidence of febrile seizures was significantly higher for children hospitalized for influenza A (19.5\%) compared to parainfluenza (12.2\%) and adenovirus (9\%) infections, controlling for age, gender, and family history of febrile seizure. In a study by Schanzer et al. among Canadian children $<19$ years of age, febrile seizures among influenza related hospital admissions occurred almost exclusively in children $<5$ years of age, with the majority in those 6 to 23 months. ${ }^{(11)}$

Influenza surveillance in Canada is conducted through the FluWatch program, which is a national network of laboratories, hospitals, sentinel physicians and provincial and territorial ministries of health. Children 24 to 59 months of age represented between $7-9 \%$ of the total cases reported annually, from the 2005-06 to the 2010-11 influenza seasons. ${ }^{(12)}$

\section{I.2.1 Outpatient visits}

Outpatient visits were assessed in 2 prospective and 2 retrospective studies with population groups and analyses for participants 24 to 59 months of age. The annual rate of influenza-attributed outpatient visits varied by study and was assessed for total outpatient and acute respiratory infection visits. 
In a 25 year prospective cohort study (1974-1999) of healthy children 5 years old or younger, Neuzil et al. found an annual incidence rate of 82 per 1,000 (95\% Cl: 65, 99) symptomatic health care visits associated with culturepositive influenza for children $24-59$ months. ${ }^{(2)}$ For children and infants $<1$ year and 1 to $<2$ years the annual rate of health care visits was 93 per 1,000 $(95 \% \mathrm{Cl}: 76,109)$ and 110 per $1,000(95 \% \mathrm{Cl}: 93,135)$ respectively.

From 2002-2004, Poehling et al. conducted a prospective population-based multi-year study in children $<5$ years of age in three US counties. ${ }^{(6)}$ Of 1742 children enrolled in outpatient settings (select clinics and emergency departments) $16 \%(n=267)$ were diagnosed with influenza. For the 267 cases of influenza 52\%, 40\% and $7 \%$ were among children 24-59, 6-23 and 0-5 months, respectively. Approximately $20 \%$ of laboratory confirmed influenza cases in the outpatient setting had a high-risk condition. For children 24 to 59 months of age the average annual rate of outpatient visits attributable to influenza $(85.5$ per 1,000$)$ was approximately 250 times higher than the hospitalization rate $(0.3$ per 1,000$)$.

Over the course of 6 influenza seasons, 1994-2000, O'Brien et al. completed a retrospective analysis of influenza attributed outpatient visits for children and adolescents 6 months to 17 years using health information databases. ${ }^{(13)}$ The estimated rate of outpatient visits among healthy children 24-59 months of age, during the influenza defined seasonal periods, was 10.2 per 100 person-months $(95 \% \mathrm{Cl}$ : $9.9,10.6)$. For children 6 to 23 months the rate of outpatient visits was 14.5 per 100 person-months $(95 \% \mathrm{Cl}$ : $13.9,15.1)$.

Bourgeois et al. completed a population based study, 1993-2004, to estimate the rate of emergency department (ED) visits for acute respiratory infections (ARI) for children $\leq 7$ years of age in Boston, Massachusetts. ${ }^{(14)}$ The estimated age-specific mean winter-season incidence of ED visits for influenza at the Children's Hospital Boston ED was 48 per 1000 (95\% Cl: 37, 62) ARI visits for children 6 to 23 months and 45 per 1,000 $(95 \% \mathrm{Cl}: 33,61) \mathrm{ARI}$ visits for children 24-59 months. The estimated age-specific mean winterseason incidence of ED visits for influenza at several Boston EDs was 22.1 per 1,000 (95\% Cl: 20.4, 23.7) ARI visits for children 6 to 23 months and 11.5 per 1,000 (95\% Cl: 10.6, 12.3) ARI visits for children $24-59$ months.

\section{I.2.2 Hospitalizations}

Hospitalization rates for children $<5$ years of age were reviewed in 6 studies, using both prospective and retrospective designs, with influenza-associated hospitalization rates varying by study. From the 2004-05 to 2010-11 influenza seasons, surveillance data from the Canadian surveillance network, Immunization Monitoring Program ACTive (IMPACT) was also reviewed for children 24 to 59 months of age.

Thompson et al. estimated the rate of influenza-associated hospitalizations, using ICD-9-CM codes and US viral surveillance and hospital discharge data from 1979 to 2001. In children $<5$ years of age the average annual rate of influenza-associated hospitalizations was approximately 1.1 per 1,000 person-years. ${ }^{(5)}$ They also found that the annual rate of influenza-associated hospitalizations for children $<5$ years of age was greater than for those 5-54 years of age across ICD-9-CM diagnostic categories for Pneumonia and influenza hospitalizations (ICD-9-CM codes 480-487) and Respiratory and circulatory hospitalizations (ICD-9-CM codes 390-519). The rate was also greater for children $<5$ years of age compared to those $50-64$ years for hospital discharge diagnosis, Respiratory and circulatory hospitalizations.

In the prospective population-based multi-year study of children $<5$ years of age by Poehling et al., $6 \%$ of the total hospital admissions enrolled $(n=2797)$ were diagnosed with influenza. Of these 160 cases, $49 \%$ were $0-5$ months, $31 \%$ were $6-23$ months and $20 \%$ were $24-59$ months. ${ }^{(6)}$ The average annual hospitalization rate for laboratoryconfirmed influenza was 0.3 per 1,000 (95\% Cl: 0.2 to 0.5$)$ children 24-59 months compared to 0.9 per 1,000 (95\% Cl: $0.7,1.2)$ children $6-23$ months and 4.5 per $1,000(95 \%$ $\mathrm{Cl}: 3.4,5.5)$ for those $0-5$ months. Approximately $20 \%$ of laboratory confirmed influenza cases in the inpatient settings had a high-risk condition.

O'Brien et al. completed a retrospective analysis, covering the years 1994-2000, of influenza attributed hospitalizations for children and adolescents 6 months to 17 years using health information databases. ${ }^{(13)}$ The estimated hospitalization rate for healthy children 24-59 months of age, during the influenza defined seasonal periods, was 5.7 per 10,000 person-months (95\% Cl: 3.0, 9.0). For healthy children 6 to 23 months the estimated hospitalization rate was 10.4 per 10,000 person-months (95\% Cl: 6.0, 17.0).

Izurieta et al. estimated the influenza hospitalization rate for children and adolescents $<18$ years of age, using data from the Kaiser Permanente Medical Care Program of Northern California and the Group Health Cooperative of Puget Sound, Seattle, from 1992 to 1997.(4) The Northern California hospitalization rate for acute respiratory disease, during periods when influenza virus predominated, for 
children without high-risk conditions was 231 per 100,000 person-months $(95 \% \mathrm{Cl}: 197,271)$ for children $<2$ years of age, 53 per 100,000 person-months ( $95 \% \mathrm{Cl}$ : 38, 72) for those 2 to 4 years of age and 19 per 100,000 personmonths $(95 \% \mathrm{Cl}: 15,24)$ for those 5 to 17 years of age. The hospitalization rate for acute respiratory disease in Puget Sound, Seattle, during periods when influenza virus predominated, for children without high-risk conditions, was 193 per 100,000 person-months $(95 \% \mathrm{Cl}: 154,238)$ for children <2 years of age, 21 per 100,000 (95\% Cl: 11, 38) for those 2 to 4 years of age, and 16 per 100,000 (95\%Cl: $12,22)$ for those 5 to 17 years of age.

Among children and adolescents $<21$ years of age, Coffin et al. found an incidence of lab-confirmed influenza related hospitalizations ( $n=231$ ) of 6.8 per 10,000 child-years $(95 \%$ Cl: $2.6,14.4)$ among their urban neighborhood cohort. ${ }^{(15)}$ For children 0-23 months the rate was 41.6 per 10,000 child-years $(95 \% \mathrm{Cl}: 30.2,56.7)$ and for children $2-4$ years of age the rate was 7.0 per 10,000 child-years $(95 \% \mathrm{Cl}: 2.8$, 14.4). Of the total sample, $77 \%$ were $<5$ years of age and $49 \%$ had a high-risk condition. Of the total influenza hospitalizations ( $n=745$ ) from 2000-2004, 18\% were among children 2-4 years of age, whereas $60 \%$ were among those $<24$ months. For children 2-4 years of age $(n=135), 39 \%$ were previously healthy. The rate of complications among healthy children was not statistically different between age groups.
From 1973-1999 Neuzil et al. conducted a retrospective cohort study of healthy children and adolescents $<15$ years of age. ${ }^{(3)}$ The standardized rate of influenza attributed cardiopulmonary hospitalizations for children 3-5 years of age was estimated at 43 per 10,000 person years, 79 per 10,000 for children 1-3 years of age and 22 per 10,000 for children 5 to 15 years of age. Similar to the other studies, rates of hospitalization were highest in the $<6$ month old age group and declined with age.

The Immunization Monitoring Program ACTive (IMPACT) is a paediatric hospital surveillance network that collects data on adverse events following immunization, vaccine failures and surveillance information on other infectious diseases in 12 centres across Canada for children and adolescents $<16$ years of age. From the 2004-05 to 2010-11 influenza seasons (see Table 1, below), the proportion of children 24 to 59 months of age hospitalized due to laboratory confirmed influenza, out of the total number of paediatric hospitalized influenza cases in children and adolescents $<16$ years of age ( $<18$ years of age during pandemic years), ranged from $20-29 \%$. 
TABLE 1: Proportion of paediatric laboratory-confirmed influenza hospitalizations among children 24-59 months of age, as reported through the Canadian Immunization Monitoring Program ACTive (IMPACT), 2004-05 to 2010-11 influenza seasons

\begin{tabular}{l|l|l|l}
\hline $\begin{array}{l}\text { Influenza } \\
\text { season }\end{array}$ & $\begin{array}{l}\text { Type of } \\
\text { season }\end{array}$ & $\begin{array}{l}\text { Proportion of paediatric hospitalizations that } \\
\text { were in children between } \mathbf{2 4} \text { to } \mathbf{5 9} \text { months of age } \\
(\%, \mathbf{n} / \mathbf{N})\end{array}$ & $\begin{array}{l}\text { Predominant age groups among } \\
\text { paediatric hospitalizations } \\
\text { (age group, \%) }\end{array}$ \\
\hline $2004-05$ & A & $20.2 \%(79 / 391)$ & $<2$ years $(54.7 \%)$ \\
\hline $2005-06$ & mix & $27.3 \%(102 / 374)$ & $<2$ years $(38.5 \%)$ \\
\hline $2006-07$ & A & $25.9 \%(96 / 370)$ & $<2$ years $(49.5 \%)$ \\
\hline $2007-08$ & mix & $23.3 \%(116 / 497)$ & $<2$ years $(46.7 \%)$ \\
\hline $2008-09^{*}$ & A & $21.9 \%(168 / 767)$ & $<2$ years $(36.2 \%) \& \geq 5$ years $(41.9 \%)$ \\
\hline $2009-10^{*}$ & A & $22.7 \%(215 / 948)$ & $<2$ years $(47.6 \%)$ \\
\hline $2010-11$ & A & $29.1 \%(195 / 671)$ & \\
\hline
\end{tabular}

* Seasons affected by the influenza A(H1N1) pandemic of 2009.

\section{I.2.3 Mortality}

The number of influenza attributed deaths is difficult to estimate directly because influenza infections are not typically confirmed virologically, or specified on hospital discharge forms or death certificates. Mortality rates were reported in two analyses of data from US surveillance systems and two studies using prospectively collected data.

Thompson et al., using US national mortality and viral surveillance data, modeled the influenza mortality rate from the 1990-1991 through 1998-1999 seasons. ${ }^{(16)}$ The estimated annual influenza mortality rate was greatest for those $\geq 65$ years of age for the following causes of death: Pneumonia and influenza deaths (ICD-9 codes 480-487), Underlying respiratory and circulatory deaths (ICD-9 codes 390-519 and ICD-10 codes 100-199, J00-J99), and All-cause deaths (all ICD codes). For children 1-4 years of age, the estimated annual influenza mortality rate, ICD-09 code Underlying pneumonia and influenza, was 0.2 per 100,000 person-years compared to 0.3 per 100,000 for those $<1$ year. For cause of death, Underlying respiratory and circulatory (ICD-9 codes), children 1-4 years had a lower estimated annual influenza mortality rate compared to those $<1$ year, 0.4 vs. 0.6, respectively. For cause of death, All-cause (all ICD codes), children 1-4 years of age had a lower estimated annual influenza mortality rate compared to those $<1$ year, 2.2 vs. 1.1, respectively. In all age groups, except those $<1$ year age, influenza was associated with more deaths than RSV.
Bhat et al., using standardized report forms, collected data on laboratory confirmed influenza-related pediatric deaths ( $<18$ years) during the 2003-2004 influenza season. Of the reported deaths $(\mathrm{n}=153), 96$ (63\%) were among children $<5$ years and $61(40 \%)$ were among children $<2$ years. ${ }^{(17)}$ Of the 149 cases for which data was reported, 33\% had an Advisory Committee on Immunization Practices high-risk condition. Overall the mortality rate declined as age increased. Louie et al., analyzed data on laboratory confirmed influenza-related pediatric deaths ( $<18$ years) during the 2003-2004 and 2004-2005 influenza seasons in California, US. Of the 160 laboratory-confirmed influenza cases reported, 15 were fatal with the following age distribution: $<6$ months $n=2,6$ to 23 months $n=5,2$ to 4 years $n=4,5$ to 11 years $n=2$ and 12 to 17 years $n=2$. Of the 15 fatal cases $27 \%$ were previously healthy. ${ }^{(8)}$

During the 2006-2007 influenza season in the US, 68 deaths were reported among those $<18$ years of age. Of the total deaths, 10 were among children $<6$ months, 10 were among children 6-23 months, 9 were among children 2-4 years, and 39 were among those 5-17 years of age..$^{(18)}$ 


\section{I.3 EFFICACY AND EFFECTIVENESS}

The efficacy and effectiveness of influenza vaccines have been shown to vary based on factors such as age, immunocompetence, similarity between the virus strains in the vaccines and those circulating in the community, and the outcome being measured. Vaccine efficacy and effectiveness studies have evaluated outcomes such as incidence of laboratory confirmed influenza, medically attended acute respiratory illness, self-reported ILI, and AOM. Given the differences between TIV and LAIV, the efficacy and effectiveness of the two vaccines are reviewed separately.

\section{I.3.1 Trivalent Inactivated Influenza Vaccines (TIV)}

During the period that was selected for the literature review, ten cohort, seven case-control, one longitudinal, one ecological, and two descriptive studies were identified assessing TIV vaccine efficacy and effectiveness. Of the eleven studies evaluating laboratory confirmed influenza, the majority of them estimated TIV to have a vaccine efficacy of $45-60 \%$ (range $39-86 \%$ ). Five studies ${ }^{(19)-(23)}$ demonstrated that in children who required two doses of vaccine, receiving both doses conferred better protection against illness and inpatient or outpatient visits than receiving one dose only. One study estimated a higher VE for partial vaccination than full vaccination, but with overlapping confidence intervals. ${ }^{(24)}$

\section{Laboratory confirmed influenza}

The incidence of laboratory confirmed influenza was the outcome assessed in eleven of the studies reviewed, with the majority using viral culture and/or RT-PCR. (20)-(28) One study used a rapid diagnostic test ${ }^{(29)}$, and another an enzyme immunoassay membrane test ${ }^{(30)}$ to confirm influenza infections.

Modest protection in children was identified in Belongia et al., (25) during the 2007-08 influenza season in Wisconsin, US. Medically-attended participants were selected for a case-control analysis from a prospective community cohort. Of 1914 participants in the study, 412 (22\%) were children 6-59 months of age. Vaccine effectiveness (VE) in children 6-59 months was 39\% (95\% Cl: 2, 62). When restricted to children who were tested 0-3 days after illness onset the VE decreased to $31 \%(95 \% \mathrm{Cl}:-24,62)$. This was the lowest estimated value when compared to the other age groups ( $48 \%$ in $5-49$ and $53 \%$ in $\geq 50$ ). Poor lineage matching of the $B$ strain was identified in the study during the 2007-08 season.
Eisenberg et al. ${ }^{(20)}$ observed both low and moderate VE during the two influenza seasons studied in a case-control study of 2,474 children 6-59 months of age with medically attended acute respiratory infections. In a subgroup analysis of fully vaccinated children 24-59 months of age, VE was estimated to be $66 \%$ (95\% Cl: $-106,94)$ in 2003/04 and $63 \%(95 \% \mathrm{Cl}: 16,84)$ in 2004/05. Partial vaccination was not effective in either season. Suboptimal matching of the vaccine and circulating strains, more significant in 2003/04 than 2004/05, was hypothesized to have had an impact on the VE estimates.

In a prospective cohort study by Heinonen et al., ${ }^{(26)} 631$ children 9 months to 3 years of age were followed during the 2007/08 influenza season in Turku, Finland. Fifty-six percent of the population was 2-3 years of age $(n=353)$, and an analysis comparing fully vaccinated to unvaccinated participants in this subgroup estimated a VE of $100 \%$ (95\% $\mathrm{Cl}: 6,100 ; p=0.05)$ against influenza $\mathrm{A}$ and $33 \%(95 \% \mathrm{Cl}:-97$, 78; $p=0.78$ ) against influenza $B$. Similar VE estimates were found in a case-control analysis of the participants, with partially vaccinated individuals considered unvaccinated.

Two multi-year studies were conducted in Japan by Joshi et al. (21) and Katayose et al.,(29) among children 6 months to $<6$ years. Joshi et al. followed 206 children 6-59 months of age from 1999/00 to 2006/07. VE comparing vaccinated to unvaccinated children was $86 \%(95 \% \mathrm{Cl}: 29,97)$ in fully vaccinated and $73 \%(95 \% \mathrm{Cl}: 3,93)$ in partially vaccinated children. Katayose et al. conducted a prospective, nonrandomized observational study in a small Japanese region between 2002/03 and 2007/08 with 14,788 children 6 months to $<6$ years of age. The VE of children 2 to $<3$ years, 3 to $<4$ years and 4 to $<5$ years of age, was $57 \%(95 \% \mathrm{Cl}: 49$, 68; $\mathrm{p}<0.01), 53 \%(95 \% \mathrm{Cl}: 42,67 ; \mathrm{p}<0.01)$, and $45 \%(95 \% \mathrm{Cl}$ : $25,67 ; p<0.01)$ respectively against illness attributed to influenza A. Against influenza B illness, VE was estimated to be $71 \%(p<0.01)$ in children 2 to $<3$ years, $60 \%(p<0.01)$ in children 3 to $<4$ years, and $51 \%(p<0.01)$ in children 4 to $<5$ years.

An Australian case-control study ${ }^{(22)}$ recruited 289 children 6-59 months of age from general practices $(n=75)$ and one paediatric emergency department $(n=214)$. Approximately half of these children were $\geq 2$ years of age. VE was estimated to be $58 \%(95 \% \mathrm{Cl}: 9,81)$, among all children, $51 \%(95 \% \mathrm{Cl}:-21,80)$ in children recruited from the emergency department, and $87 \%(95 \% \mathrm{Cl}: 8,98)$ in children from general practices. TIV was more effective against influenza A (VE: 82\%, 95\% Cl: 21, 96), than influenza B, where the VE was $43 \%(95 \% \mathrm{Cl}:-39,77)$. The higher VE in children in the general practice study arm may be the result 
of a single general practice with a vigorous childhood immunization program which contributed half of the arm's study participants. In this general practice, $64 \%$ of children from the general practice were fully vaccinated compared to $37 \%$ of children from the emergency department. Thirteen cases of vaccine failure were reported, nine of which were due to a mismatch in the influenza B strain.

Szilagyi et al. ${ }^{(28)}$ conducted a case cohort study, enrolling 9,468 in-patient and 1,438 out-patient children 6-59 months over two influenza seasons between 2003 and 2005 in the US. Cases were identified prospectively by visits for acute respiratory infection and controls were retrieved and age-stratified retrospectively from medical records. VE for children 24-59 months of age ranged from -108\% to $77 \%$ for fully vaccinated and partially vaccinated children over the two influenza seasons, none of which were statistically significant estimates. As noted in other studies, suboptimal antigenic matching between vaccine and circulating strains in 2003/04 and 2004/05 affected the ability to demonstrate VE in preventing influenza-related in-patient or out-patient visits.

Shuler et al.(24) followed 870 children 6-59 months of age from a single paediatric clinic in a case-control study in Georgia, US. Controls were aged matched, by month, to cases with laboratory confirmed influenza in a 2:1 ratio. Adjusting for high-risk conditions and health care usage, a subgroup analysis of children 24-59 months of age estimated a VE of $45 \%$ (OR: $0.55,95 \% \mathrm{Cl}: 0.3,0.9 ; \mathrm{p}<0.05$ ) in fully vaccinated compared to unvaccinated children. Partially vaccinated children in this age group experienced a higher VE of 65\% (OR: 0.35, 95\% Cl: 0.2, 0.7; $p<0.05)$, however the confidence intervals overlap. VE of partial vaccination was insignificant when estimated for the entire study population. As noted in other studies, suboptimal antigenic matching between vaccine and circulating strains was identified as a factor in the 2003/04 season.

Over two influenza seasons, between 2005 and 2007, Staat et al. ${ }^{(23)}$ conducted a prospective, population-based case-control study in children 6-59 months of age in the US. Controls were matched to cases by regional site, highest level of care received, age group, and date of illness onset. Children were enrolled in the study from in-patient and out-patient facilities, with 268 children enrolled in 2005-06 and 528 in 2006-07. The analysis of children 24-59 months of age estimated a VE of $43 \%$ (95\%
$\mathrm{Cl}:-62,80)$ in the first season, and $76 \%(95 \% \mathrm{Cl}:-16,95)$ in the second in fully vaccinated children. The estimated VE in partially vaccinated children was $6 \%(95 \% \mathrm{Cl}:-330,80)$ and $44 \%$ (95\% Cl: $-77,82)$ in the first and second seasons, respectively. Combining both seasons, VE was $56 \%$ (95\% $\mathrm{Cl}: 3,80)$ in fully vaccinated and $34 \%(95 \% \mathrm{Cl}:-64,73)$ in partially vaccinated children.

\section{Influenza-like illness}

ILI was assessed in five unique studies, four of which were medically attended (out-patient clinic or emergency department). ${ }^{(19)(31)-(34)}$ All studies noted reductions in the outcome of interest in vaccinated children.

Ghendon et al. ${ }^{(32)}$ studied the clinical effectiveness of TIV in a mass vaccination campaign in school-aged children in Russia. Comparing rates of physician-diagnosed ILI (temperature $>38^{\circ} \mathrm{C}$ with cough or sore throat) in two intervention and two control communities, healthy children 3-6 years of age experienced 2.56 times fewer cases of illness, with a vaccine effectiveness of $60.9 \%(p<0.01)$. There was a good antigenic match between vaccine and circulating $\mathrm{A} / \mathrm{H} 3 \mathrm{~N} 2$ and $\mathrm{B}$ strains during the study season.

Two studies by Ritzwoller et al. ${ }^{(19)}$ and Hoen et al. ${ }^{(35)}$ reviewed patient health records to assess ILI-related outcomes among pediatric populations in the US and Canada. In a retrospective cohort study, Ritzwoller et al. reviewed electronic records of outpatient and emergency department visits in Colorado, US for ILI and pneumonia and influenza (P\&I) outcomes in children 6 months to 8 years of age. Approximately $92 \%$ of the ILI events and $90.5 \%$ of $\mathrm{P} \& \mathrm{l}$ events were recorded from outpatient facilities. The hazard rate ratio (HRR) adjusted for sex, age and prior illness against ILI was 0.77 (95\% Cl: 0.66, 0.90; $\mathrm{p}<0.001)$ in fully vaccinated children $2-8$ years of age, and was not statistically significant in partially vaccinated children. Against $P \& l$, fully vaccinated children experienced a protective effect with an HRR of 0.49 (95\% Cl: 0.36, 0.67; $p<0.001$ ), while the effect was lessened in the partially vaccinated children with an HRR of 0.77 (95\% Cl: 0.62, 0.95; $\mathrm{p}<0.001)$. The ecological study by Hoen et al. reviewed ILI-related paediatric emergency department visits from 2000/01 to 2008/09 in a Canadian and American hospital. In 2006/07, the ACIP recommendation to vaccinate all children 2-5 years of age was introduced, and a reduction in visits was subsequently observed (rate ratio: $0.66,95 \%$ 
$\mathrm{Cl}: 0.58,0.75)$ in children $2-4$ years of age in the US compared to the Canadian hospital. However, this study does not consider differences in factors such as demographics or the health care systems of the two cities studied, and estimates vaccination rates from other community-based surveys.

One prospective cohort study of paediatric clinics across $J_{a p a n}{ }^{(31)}$ assessed the incidence of ILI and frequency of medical office visits in vaccinated and unvaccinated children less than six years of age using parental symptom reports and clinic records. The adjusted odds ratio was significant only during the peak epidemic period for severe ILI (ILI with fever $\geq 39.0^{\circ} \mathrm{C}$ ) OR: 0.75 ( $95 \% \mathrm{Cl}$ : 0.58, 0.91; $\mathrm{p}=0.031$ ), and only among children $3.0-3.9$ years of age (OR: $0.50,95 \% \mathrm{Cl}: 0.26,0.96$ ), although the authors suggest this may be the result of reduced statistical power when conducting subgroup analyses. When all children are included in the analysis, a small reduction in medical office visits related to severe ILI between vaccinated and unvaccinated children was observed (OR: $0.73,95 \% \mathrm{Cl}$ : $0.59,0.96 ; p=0.023)$. Medical visits for any cause was also lower in vaccinated children (OR: 0.79, 95\% Cl: 0.64, 0.98; $\mathrm{p}=0.028$ ) when all children were included.

The multicentre cohort study by Fujieda et al. ${ }^{(33)(34)}$ recruited participants from paediatric clinics, identifying febrile cases using parental reports. From a sample of 2913 children $<6$ years of age, with vaccination status selfselected by parents, vaccine effectiveness among children 2.0-5.9 years of age was $33 \%$ (95\% Cl: $21,44 \%)$. In the analysis of smaller age categories, the OR was statistically significant for children 2.0-2.9 (0.61, 95\% Cl: 0.44, 0.84; $\mathrm{p}=0.002)$ and $3.0-3.9$ years of age $(0.60,95 \% \mathrm{Cl}: 0.43,0.84$; $\mathrm{p}=0.003$ ), but not for children 4.0-4.9 years of age.

\section{Hospitalizations}

Based on the search completed for the evidence review, only two studies were found to assess hospitalizations related to influenza in this age group. The observational study by Katayose et al. ${ }^{(29)}$ evaluated VE for two doses of TIV against influenza $A$ and $B$ hospitalizations in Japan. Over 6 influenza seasons of follow-up, VE of children 2 to $<3$ years, 3 to $<4$ years and 4 to $<5$ years of age for influenza A were 61\% ( $p<0.05), 74 \%(p<0.01), 74 \%(p<0.01)$. VE for influenza B hospitalizations ranged from $68-88 \%$, but were not significant. In Dixon et al., ${ }^{(27)}$ the VE in fully vaccinated compared to unvaccinated children in Western Australia admitted to hospital with laboratory confirmed positive and negative influenza, was $83 \%$, although not significant.

\section{I.3.2 Live Attenuated Influenza Vaccines (LAIV)}

Six studies evaluating vaccine efficacy and effectiveness were reviewed. All six studies were RCTs, five of which used an outcome of laboratory confirmed influenza, and one assessing over-the counter medication and prescription drug use. Three studies were community-based field trials evaluating medically attended acute respiratory illness for communities where a mass vaccination campaign in school-age children was introduced. VE estimates ranged from $44-85 \%$, with most estimates falling between $50 \%$ and $85 \%$ for laboratory confirmed influenza. Given the relatively new entry of LAIV into the market, fewer of these studies assessed or conducted subgroup analyses specifically for children 24-59 months of age. For further details on LAIV please see the Recommendations on the use of live, attenuated influenza vaccine (FluMist ${ }^{\circledR}$ ) Supplemental Statement on Seasonal Influenza Vaccine for 2011-2012 at http://www.phac-aspc.gc.ca/publicat/ccdr-rmtc/11vol37/ acs-dcc-7/index-eng.php. ${ }^{(36)}$

\section{Laboratory confirmed influenza}

In an RCT of LAIV and TIV, Ashkenazi et al. ${ }^{(37)}$ randomized 2187 children 6 to 71 months of age with a history of recurrent respiratory tract infections (RTIs), including, but not limited to, common colds, acute otitis media, bronchitis, pneumonia, and bronchiolitis. From this population, 2,085 children were evaluated for efficacy in the per protocol population. There were 53\% (95\% Cl: 22, 72) fewer cases of culture-confirmed influenza caused by vaccine-matched strains among recipients of LAIV compared with recipients of TIV (24/1,050 versus 50/1,035, respectively). In the study's evaluation of health outcomes related to all-cause respiratory illness (i.e. influenza and non-influenza), LAIV recipients reported $9 \%(95 \% \mathrm{Cl}: 2,16)$ fewer health care provider visit days and $16 \%(95 \% \mathrm{Cl}: 10,22)$ fewer missed days from school or child care, compared with TIV recipients. There was no impact noted on medication or antibiotic treatment for respiratory tract infections, overnight hospitalizations or wheezing associated with influenza-like illness. In a post hoc analysis, ${ }^{(38)}$ LAIV was found to decrease the severity of influenza illness that occurred despite vaccination (breakthrough influenza) compared to TIV.

In 2004-2005, Belshe et al. ${ }^{(39)}$ compared the efficacy of LAIV and TIV in a multinational, randomized, double-blind study in 7,852 children 6 to 59 months of age. Study groups were well matched with regard to history of prior influenza vaccination (22-23\%), history of wheezing (21-22\%), recurrent wheezing (6-7\%), and asthma (4\%). An 
investigation for influenza illness was initiated upon report of fever plus $\geq 1$ other symptom of cough, sore throat, or runny nose/nasal congestion. There were $45 \%$ (95\% Cl: 22 , 61) fewer cases of influenza caused by matched strains in LAIV recipients than TIV recipients (53/3,916 versus $93 / 3,936$, respectively), and 58\% (95\% Cl: 47,67$)$ fewer cases caused by mismatched strains (102/3 916 versus $245 / 3,936$, respectively). In a post-hoc analysis ${ }^{(40)}$ of children aged 24-35, 36-47 and 48-59 months of age, the relative efficacy of LAIV versus TIV was $57 \%$ (95\% Cl: 40,69$), 42 \%$ (95\% Cl: 5,66$)$, and $56 \%(95 \% \mathrm{Cl}: 25,75)$ respectively for all influenza strains.

The randomized, multi-year, placebo controlled studies by Tam et al. and Vesikari et al. conducted in two seasons (2000 to 2002) found LAIV to be efficacious in preventing culture-confirmed influenza caused by antigenically matched strains in vaccinated and revaccinated children. The first study by Tam et al. ${ }^{(41)}$ was conducted in eight Asian countries with healthy children 12 to 35 months of age (first year overall vaccine efficacy $73 \%, 95 \% \mathrm{Cl}$ : 62,80 ; second year overall efficacy $84 \%, 95 \% \mathrm{Cl}: 70,92)$. The second study by Vesikari et al. ${ }^{(42)}$ involved healthy children 6 to 35 months of age attending daycare in five European countries (first year overall vaccine efficacy $85 \%, 95 \% \mathrm{Cl}$ : 74,92; second year overall efficacy $89 \%$, 95\% Cl: 82,93). In Tam et al., there were insufficient cases of $\mathrm{A} / \mathrm{H} 1 \mathrm{~N} 1$ or $\mathrm{B}$ strains to determine statistical significance, but efficacy against those strains was later determined by assessing reductions in medically attended acute respiratory illness (MAARI) against a drifted A/H1N1 and B strain by Gaglani et al. and Halloran et al. ${ }^{(43)}$ In Vesikari et al., when there was a good match between vaccine and circulating strains, efficacy against $\mathrm{A} / \mathrm{H} 1 \mathrm{~N} 1$ strains was $91.8 \%(95 \% \mathrm{Cl}: 80.8,97.1)$ in year one, and $90.0 \%$ (95\% Cl: $56.3,98.9)$ in year two. Efficacy against influenza B strains was $72.6 \%(95 \% \mathrm{Cl}: 38.6,88.9)$ in year one and $81.7 \%$ (95\% Cl: $53.7,91.9)$ in year two. Efficacy against A/H3N2 was not assessed in the first year, but in the second year when it was the predominantly circulating strain, efficacy was $90.3 \%(95 \% \mathrm{Cl}: 82.9,94.9)$.

Similarly, a study by Bracco Neto et al.(44), conducted with healthy vaccine-naive children 6 to $<36$ months of age during the 2001 and 2002 influenza seasons in South Africa, Brazil and Argentina, found a reduction in cultureconfirmed influenza caused by matched and mismatched strains. In year one, vaccine efficacy versus placebo in children vaccinated with one or two doses of LAIV was $57.7 \%(95 \% \mathrm{Cl}: 44.7,67.9)$ and $73.5 \%(95 \% \mathrm{Cl}: 63.6,81.0)$ respectively, against matched strains. In year two, absolute efficacy of a single dose of LAIV was $65.2 \%$ (95\% Cl: 31.2 , $82.8)$ and $73.6 \%(95 \% \mathrm{Cl}: 33.3,91.2)$ respectively, in recipients of one or two doses of LAIV in year one. Year two efficacy in recipients who received two doses of LAIV in year one and placebo in year two was $57 \%(95 \% \mathrm{Cl}: 6.1$, 81.7) against antigenically similar strains compared to those who received placebo in both years. Efficacy was 35.3\% (95\% Cl: $-0.3,58.7)$ and $20.4 \%$ against any community acquired strain and antigenically dissimilar influenza B strains, respectively. In addition, when the groups who received placebo in year one and either one dose of LAIV or placebo in year two were compared, efficacy of a single dose of LAIV was $60.3 \%$ against matched strains and $59.4 \%$ (95\% Cl: $32.3,76.4)$ against any community strain and $54.9 \%$ (95\% Cl:16.6, 76.6) against mismatched B strains.

The absolute efficacy of LAIV in young children has been further documented by a 2009 meta-analysis by Rhorer et al. ${ }^{(45)}$ examining efficacy against culture-confirmed influenza as compared to placebo in randomized clinical trials in 25,000 children 6 to 71 months of age. In this analysis, combined year one vaccine efficacy (relative to placebo) for two doses in vaccine-naïve young children was $77 \%$ $(p<0.001)$ against matched strains and $72 \%(p<0.001)$ against strains regardless of antigenic match in the per protocol population. It was noted that efficacy varied by strain, showing that vaccine efficacy versus placebo after two doses was $85 \%$ (95\% Cl: 78,90), 76\% (95\% Cl: 70, 81), and $73 \%(95 \% \mathrm{Cl}: 63,80)$ against antigenically similar $\mathrm{A} /$ $\mathrm{H} 1 \mathrm{~N} 1, \mathrm{~A} / \mathrm{H} 3 \mathrm{~N} 2$, and $\mathrm{B}$ respectively.

In summary, LAIV shows high vaccine efficacy in children across all age groups when compared with placebo, regardless of the circulating subtype.

\section{ILI and medically attended acute respiratory illness}

In non-randomized, community-based studies, other measures of vaccine effectiveness have been evaluated. Gaglani et al. ${ }^{(43)}$ studied healthy children aged 18 months to 18 years across three influenza seasons (1998 to 2001) in Texas, US. The study measured the direct effectiveness of LAIV against influenza $A / H 1 N 1$ and $B$ infections by comparing rates of medically attended acute respiratory illness (MAARI) in LAIV recipients and age-eligible nonrecipients in the intervention communities. A single dose of LAIV was received by $9,765 / 19,700$ children aged 1.5 to 18 years during the study. Individuals aged 1.5 to 4 years of age who had received LAIV for three consecutive years up to and including 2000-2001 demonstrated overall direct effectiveness of $20 \%(95 \% \mathrm{Cl}: 10,28)$ on decreasing MAARI during the weeks in the 2000-2001 influenza season with an identified influenza A and B epidemic, and $16 \%(95 \% \mathrm{Cl}$ : 1 , 
28) during the weeks where only influenza $A$ (H1N1) was predominant. The study also measured the total effectiveness of LAIV by comparing MAARI for LAIV recipients with that of non-recipients in comparison communities where LAIV was not offered. Individuals aged 2.5 to 4 years of age who had received LAIV for three consecutive years demonstrated a total effectiveness of $18 \%(95 \% \mathrm{Cl}: 8,26)$ on decreasing MAARI during the weeks with an identified influenza $A$ and $B$ epidemic, and $16 \%$ $(95 \% \mathrm{Cl}: 2,28)$ during the weeks where only influenza $A$ (H1N1) was predominant.

\section{I.3.3 Acute Otitis Media}

TIV and LAIV have been demonstrated to reduce the incidence of AOM. In a prospective cohort study by Ozgur et al., ${ }^{(46)} 119$ children, 6 to 60 months of age, attending daycare centres in Ankara, Turkey were assessed for AOM, otitis media with effusion (OME), and OM (AOM and OME events combined) every six weeks for six months for one influenza season. At the end of the study period, fewer cases of AOM (2.3\% vs. $5.2 \%, p=0.012)$, OME (22.8\% vs. $31.1 \%, \mathrm{p}=0.002)$, and $\mathrm{OM}(25.2 \%$ vs. $36.3 \%, \mathrm{p}<0.001)$ were found in children who received TIV compared to those who received no vaccine. The frequency of $A O M, O M E$ and $O M$ between the two groups was not statistically different before or after the influenza season. The calculated vaccine effectiveness against $A O M$ was $50.9 \%$. In the study by Belshe et al., ${ }^{(39)}$ comparing LAIV to TIV, there was a reduction in otitis media of $51 \%(95 \% \mathrm{Cl}: 22-70 \%)$ and lower respiratory tract illness of $46 \%$ (95\% Cl: $4-70 \%$ ) for all strains combined, regardless of match to the vaccine.

\subsubsection{Indirect Protection}

While vaccinating healthy children 24-59 months of age results in a direct benefit in the reduction of influenzarelated outcomes, there is also evidence that benefits are extended to household and other contacts in the community. Studies have shown that family members of influenza-vaccinated healthy children experience fewer influenza-related illnesses or respiratory-tract infections, medical visits, missed working or school days, and require fewer antibiotic prescriptions and over-the-counter medication. ${ }^{(32)(47)(48)}$ In studies with community-wide influenza vaccination programs for children, not necessarily restricted to those 24-59 months of age, reduced rates of MAARI were observed in intervention communities for adults $\geq 35$ years of age. ${ }^{(49)}$ A Canadian study conducted in Hutterite communities estimated indirect vaccine protectiveness at $61 \%(95 \% \mathrm{Cl}: 8,83 \%, p=0.03)$ for non-recipients of the influenza vaccine (individuals who were $>15$ years of age). ${ }^{(50)}$
Using a dynamic transmission model, Pitman et al.(51) assessed the indirect impact of pediatric (age 2-18 years) immunization with LAIV on the larger population in England and Wales. Assuming 80\% VE and 80\% coverage in those 2-5 years of age over a 15 year timeframe (20092024), the model predicted an annual average of 2.4 million cases averted ( $<2$ years: 106,$000 ; 5-18$ years; 1 million; 19-49 years: 840,$000 ; 50-64$ years: 310,$000 ; 65+$ years: $75,000)$. Additionally, the model estimated that there would be a reduction in the mean annual number of general practice consultations, hospitalisations and deaths in the entire England and Wales population of $44 \%, 40 \%$ and $36 \%$ respectively.

\section{I.4 IMMUNOGENICITY}

Studies have demonstrated that TIV and LAIV are immunogenic in children 24-59 months of age. ${ }^{(41)(52)-(54)}$ TIV is typically more immunogenic with increasing age in paediatric populations, however, TIV-induced immunity is observed to be more durable in adults. ${ }^{(5)}$ When using TIV, a better immunogenic response is observed when children have been primed by natural infection or previous influenza vaccination. ${ }^{(7)(56)}$

LAIV has been shown to be equally if not more immunogenic than TIV in children. It is thought that with LAIV, exposure to more antigens presented by a live vaccine virus causes an immune response that mimics the response induced by natural infection with wild-type viruses. LAIV may stimulate a mucosal IgA and/or T-cell-mediated immune response, and the production of more broadly cross-reactive humoral antibodies that can confer crossprotection in circumstances where there is a suboptimal match of the vaccine and epidemic influenza strains. (See FluMist Statement at http://www.phac-aspc.gc.ca/publicat/ ccdr-rmtc/11vol37/acs-dcc-7/index-eng.php for more information on the immunogenicity of LAIV. ${ }^{(36)}$

\section{I.5 SAFETY}

Based on evidence from randomized clinical trials, other analytical studies and postmarketing surveillance data, live attenuated and trivalent inactivated influenza vaccines have been shown to be safe and well tolerated among children 24 to 59 months of age. Rates of adverse events following immunization are low with rates of serious adverse events even lower. The safety of LAIV and trivalent inactivated influenza vaccines (TIV) will be discussed separately below. 


\section{I.5.1 Trivalent Inactivated Influenza Vaccines (TIV)}

The assessment of TIV safety data for children 24-59 months was primarily based on five randomized, activecontrolled trials, ${ }^{(37)(39)(54)(57)(58)}$ a self-controlled screening study, ${ }^{\left({ }^{(9)}\right)}$ and a community-based cohort study. ${ }^{(32)}$ Safety was also assessed using postmarketing surveillance data from the US and Canada, ${ }^{(60)(61)}$ as well as other completed reviews. Several of the studies reviewed included both TIV and LAIV study arms. These studies are described in detail in section 1.5.3, below.

The safety of TIV among children 24-59 months has been assessed using standard solicited adverse events (AE) (local and systemic) including erythema, pain/tenderness, swelling, interference with limb movement, malaise, drowsiness, fever, irritability/fussiness, loss of appetite, headache and myalgia, as well as unsolicited events. ${ }^{(39)(57)(58)}$

Frequently reported events among TIV recipients include tenderness / injection site pain, runny nose / nasal congestion, cough, decreased appetite, irritability and fever. ${ }^{(37)(38)(57)(58)}$ Several studies reported that the majority of reactogenicity and local and systemic adverse events were mild to moderate and transient. (38)/(39)(57) Additionally, for a number of the studies reviewed no serious adverse events $(\mathrm{SAE})^{(32)(54) / 57 /(58)}$ or death $s^{(37)(39)(57)}$ considered related to study vaccines were reported.

Glanz et al. ${ }^{(59)}$ completed a self-controlled case series analysis among children 24-59 months who had been provided care through one of seven managed care organizations (MCO) in the US. The authors searched the MCO databases for medically attended events (MAE) using ICD-09-CM codes. Following the intial screening for ICD-09-CM codes the authors confirmed MAE through a medical record review. In their analysis of less serious conditions, the authors found that medically attended limb soreness was significantly associated with TIV in the 2 days following vaccination $(p=0.04)$. The only potentially serious condition associated with vaccination was aggravated GI tract disorders among the sub-cohort of children with a high-risk condition (incidence rate ratio (IRR) $7.70(95 \% \mathrm{Cl}$ : 1.11-53.52)). The authors also found that in their analysis of annual doses over multiple years, there was no significant trend observed for MAE (non-confirmed through medical record review) with increasing doses, from 2 to 5 . Due to the small number of MAE for dose 4 and 5 and the nonsignificant trend, the clinical relevance of these findings are difficult to interpret. ${ }^{(59)}$
In a randomized, active-controlled trial among children 6 months to 18 years by Baxter et al., ${ }^{(57)}$ comparing Fluarix ${ }^{\circledR}$ and Fluzone ${ }^{\circledR}$, the rates of local adverse events (pain, redness and swelling) were similar between both TIV study arms for participants 6-36 months and 3-5 years. For both study groups, the percentage of children presenting with pain, redness and swelling was less than 50\%, 30\% and $20 \%$, respectively. Systemic events were also similar for children 6 months to $<5$ years across study groups, with the percentage of children presenting with drowsiness, fever, irritability and loss of appetite less than 30\%, 15\%, $40 \%$ and $25 \%$ respectively. ${ }^{(57)}$ Baxter et al. also reported that there were no fatal events and that no SAE were considered casually related to the study vaccines.

Postmarketing surveillance of adverse events can provide important safety data on licensed/authorized vaccines, including the detection of new adverse events and signals. In Canada and the US postmarketing safety data is collected through passive surveillance systems, with data reported on a voluntary basis. Although such systems can provide important safety signals, the size of the population at risk cannot be determined and therefore it is not possible to estimate the incidence of adverse vaccine events or establish causal relationships.

In Canada, data from the Canadian Adverse Events Following Immunization Surveillance System (CAEFISS)(61) has shown seasonal Influenza vaccines to be safe with a stable AEFI profile and no new or unexpected events, except for a notable signal in 2000/2001 related to ORS. From 2000/2001 to 2011/2012 a total of 15,813 adverse events following immunization (AEFI) reports, 520 serious, have been submitted to CAEFISS for all age groups. Of those reports, 949 were in children 2 to $<6$ years of age, with $6 \%(n=59)$ reported as serious. For this age group the mean and median age is 3.7 years, with $25 \%$ of the reports (including serious reports) for children between 2 to $<3$ years of age. Among children 2 to $<6$ years there were no fatalities or cases of residual disability reported. Local reactions were the most commonly reported AEFls (35\% of reports), followed by rashes, fever, allergic and gastrointestinal symptoms (10\% of reports). Fevers, convulsions, rashes, cellulitis and allergic reactions were the most common groups of symptoms reported for serious cases. Medical history information was available for only $24 \%$ of reports, with allergies and asthma being the most common concomitant conditions described. 
Using data from the US, Centers for Disease Control and Prevention, Vaccine Adverse Event Reporting System (VAERS), Muhammad et al. conducted a review of reported events for TIV from 1990-2006 for children and adolescents 2 to 17 years of age. ${ }^{(60)}$ The number of estimated influenza vaccinations in children 24-59 months in 2004-05 was $2,481,771$. Their analysis did not produce any new or unexpected $\mathrm{AE}$. Of the total reported events among those 2-17 years ( $n=2054), 40 \%$ were among those $24-59$ months. Among the adverse events reported for children 24-59 months ( $n=819$ ), $47 \%$ had a previous dose of TIV. Among reported $A E, 44 \%$ were among females and the median age was 3 years (range 2-4.9 years). From 1990-2006 there were 10 deaths reported among those 24-59 months of age. All of these deaths were among children with underlying chronic conditions, which may have contributed to their death. Also reported among this age group were five cases of GBS. Of these cases, four were verified, three of which occurred within four weeks of vaccination and the fourth within nine weeks. Three of the cases had a preceding illness, including viral syndrome, fever/ dysuria and strep throat.

\section{I.5.2 Live Attenuated Influenza Vaccines (LAIV)}

The assessment of LAIV safety data for children 24-59 months was primarily based on data from nine randomized controlled trials, ${ }^{(3) /(39)(41)(42)(44)(54)(62)-(64)}$ and one prospective, open label, non- randomized trial. (49) Safety was also assessed using postmarketing surveillance data from the US and Canada, ${ }^{(36)(61)}$ as well as other completed reviews and the Recommendations on the use of live, attenuated influenza vaccine (FluMist ${ }^{\circledR}$ ): Supplemental Statement on Seasonal Influenza Vaccine for 2011-2012.(36) As noted above, several of the studies reviewed included both TIV and LAIV study arms. These studies are described in detail in section I.5.3 below.

The safety of LAIV has been assessed using several solicited and unsolicited reactogenic and adverse events (AE) (local and systemic) including runny nose, nasal congestion, malaise, drowsiness, fever, cough, sore throat, irritability/fussiness, loss of appetite, headache and myal gia. ${ }^{(39)(41)(54)(64)}$ In several studies reviewed, reactogenicity and local and systemic adverse events have been shown to be mild to moderate and transient. ${ }^{(38)(39)(63)(65)}$ Frequently reported events among LAIV recipients include runny/stuffy nose, cough, decreased appetite, irritability, abdominal pain, decreased activity, headache, vomiting, sore throat, muscle ache, chills, URI and fever. . $^{(36)(37)(42)(44)(54)(63) /(65)(67)}$
In a number of the studies reviewed no $\mathrm{SAE}^{(49) / 54)(62)(64)(66)(67)}$ or deaths (Belshe 2004) $)^{(37)(41)(42)(44)(65)}$ considered related to study vaccines were reported.

In the randomized, placebo-controlled LAIV trial by Bracco et al., ${ }^{(44)}$ among healthy children 6-36 months, the proportion of recipients reporting $\geq 1 \mathrm{AE}$ was similar across study arms. The authors also reported that during follow-up days 0-11, no statistically significant differences in specific $A E$, including respiratory event reports, were found between LAIV and placebo groups in year 1 and 2, except for gastroenteritis which was reported more frequently among placebo recipients $(p=0.017)$. In their assessment of follow-up, days $0-28$, the only significant difference was a greater percentage of bronchitis among LAIV recipients, $3.1 \%$ compared to $1.6 \%(p=0.046)$ in year $2 .{ }^{(44)}$

In their randomized, placebo-controlled trial among children 6-36 months, Brieman et al. ${ }^{(63)}$ compared outcomes across three study groups, LAIV and oral poliovirus vaccine (OPV), placebo and OPV, and LAIV only. Brieman et al. found that the proportion of participants with $\geq 1$ solicited systemic reactogenicity event and the percentage of those reporting $\geq 1$ serious $A E$ were similar among study arms. When looking at specific events, runny nose / nasal congestion was reported more frequently among LAIV recipients $(p=0.003)$, while fever $\left(\geq 40^{\circ} \mathrm{C}\right)(p=0.037)$ and decreased activity $(p=0.017)$ were reported more frequently among the placebo group. The authors also reported that the frequency of unsolicited AEs were similar across study arms following dose 1 and 2, except for conjunctivitis which was reported more frequently, only following dose 1 , among the LAIV only group, $0.7 \%$ compared to $0.1 \%$ for both the LAIV and OPV and placebo and OPV group $(p=0.04) .{ }^{(63)}$

In a randomized, placebo-controlled LAIV trial among healthy children 6-36 months by Vesikari et al., ${ }^{(42)}$ similar proportions of recipients reported $\geq 1$ reactogenicity event between study arms in year one (dose 1 LAIV 97.1\% vs placebo $96.8 \%, p=0.764$; dose 2 LAIV $95.5 \%$ vs placebo $95.3 \%$ ) and in year 2 (LAIV $80.5 \%$ vs placebo $79.0 \%$, $\mathrm{p}=0.583)$. The only significant difference was seen in the proportion of runny nose / nasal discharge in year one, with a greater number of cases $(p=0.001)$ reported in the LAIV study arm. AE reports for upper respiratory infection (URI) and lower respiratory infection (LRI) were uncommon and were also similar across study groups. Serious adverse events reported in year one were similar between the LAIV and placebo groups. During the first influenza season $9 \mathrm{SAE}$ judged to be probably, possibly or maybe related to study vaccines were reported among LAIV recipients and 
5 among placebo recipients. In the second influenza season there were 2 SAE possibly, probably or definitely related to LAIV. In year two there was no statistically significant difference in SAE between LAIV and placebo groups. ${ }^{\left({ }^{(2)}\right)}$

In the open-label, non-randomized, community-based trial by Piedra et al., ${ }^{(49)}$ participants 18 months to 4 years had no significant increase in health care usage for medically attended acute respiratory illness (MAARI), MAARI subcategories, or asthma comparing pre and post vaccination for days 0-14 over the four years of the study. In assessing the 15-42 day follow-up period post vaccination, the only significant increase in health care utilization compared to the pre-vaccination period was for asthma in year one, RR 2.85 (95\% Cl:1.01-8.03), which was not observed in the following 3 years of the study. The authors also reported that the RR for MAARI, post-vaccination (days 0-14) compared to pre-vaccination period, did not differ significantly for children 18 months to 4 years who had received 2,3 , and 4 annual sequential doses. ${ }^{(49)}$

Neuzil et al. ${ }^{(54)}$ reanalyzed data from an earlier randomized, controlled trial, using a subset of the original data for participants $1-16$ years of age. Rates of systemic reactogenicity events (fever, cough, coryza and sore throat) were found to be similar in all age groups ( 1 to $<6$ years, 6 to $<11$ years and 11 to $<16$ years) and across study years 2 to $5 .{ }^{(54)}$

In the randomized, placebo-controlled trial by Bergen et al., (62) among children 1-8 years of age, the risk of upper respiratory tract infections, asthma and musculoskeletal pain was greater among participants 18-35 months of age in the LAIV group. Among the asthma events reported, none required hospitalizations and $44 \%$ of cases in the LAIV group were among participants with a previous clinic visit for asthma. ${ }^{(62)}$

Piedra et al. ${ }^{(64)}$ assessed the safety of LAIV among children 15 to 71 months of age in a multi-site, randomized, placebo-controlled trial. In their multivariate analysis, controlling for age, child care attendance and month of vaccination, they found that the odds of runny nose/nasal congestion (OR 1.61 (95\% Cl: 1.30-1.99), vomiting (OR 1.78 (95\% Cl:1.05-3.01), muscle ache (OR 2.0 (95\% Cl:1.10-3.65) and fever (OR 1.52 (95\% Cl:1.11-2.07) were significantly greater for LAIV recipients compared to placebo in year 1 following dose 1 . Following dose 2 the only significant difference was for runny nose/nasal congestion, OR 1.29 (95\% Cl: 1.02-1.65), with no significant differences found in year $2 .{ }^{(64)}$
In a review including randomized placebo controlled LAIV trials by Ambrose et al., ${ }^{(38)}$ the proportion of subjects reporting $\geq 1 \mathrm{AE}$ was similar between the LAIV and placebo groups during the first 10 days following immunization, in years 1 and 2, although some differences were noted for specific AE. Ambrose et al. found that the rates of runny/ stuffy nose, headache, and tiredness / decreased activity in year 1 following dose 1 were significantly higher among LAIV compared to placebo recipients with rate differences of $6.8 \%(p<0.01), 6.9 \%(p=0.02)$, and $2.1 \%(p=0.03)$, respectively. After dose 2 the rate of decreased appetite was significantly lower among LAIV recipients compared to the placebo group (rate difference $2.9 \% ; p=0.04$ ). In year 2 , the only statistically significant difference was a higher rate of decreased appetite among LAIV recipients (rate difference, $3.9 \% ; p=0.03$ ). For unsolicited $A E$ the rate of general disorders $(p<0.01)$ was greater in the LAIV group, whereas ear disorders (year 1 , dose 2$)(p=0.02)$ and lower respiratory illnesses $(p=0.03)$ were significantly lower among the LAIV compared to the placebo group. A consistent trend across all reactogenicity events and AEs was that rate differences were lower after revaccination in years 1 and 2 compared with the initial vaccination. ${ }^{(38)}$

In their analysis, Ambrose et al. found similar rates of any SAE (observation period 0-42 days) reported for LAIV and placebo groups, $0.5 \%$ and $0.6 \%$ respectively for both year 1 and 2. For the observation period, $0-180$ days, $2.9 \%$ of LAIV and $2.7 \%$ of placebo recipients reported any SAE in year 1 , and $2.1 \%$ of LAIV and $1.7 \%$ of placebo recipients reported any SAE in year 2. The authors also report similar rates of lower respiratory / wheezing illness for LAIV and placebo groups for children aged 24-35 months, except following dose 2 in year 1, when the incidence was lower among LAIV recipients $(p=0.03)$. Among this age group, when analyzed by subject region and gender, the patterns of reactogenicity events (RE), $A E$, and SAEs were consistent with those observed in the overall population. ${ }^{(38)}$

In a prospective, randomized, placebo-controlled study of three LAIV lots among children 12-36 months by Zangwill et al., ${ }^{(66)}$ runny nose / nasal congestion was significantly higher for LAIV lots compared to placebo (63 to $68 \%$ for LAIV lots vs. $49 \%$ in placebo, $p<0.05$ ). Significant differences, LAIV vs placebo, were also seen for headache following dose 1 (6 to $11 \%$ LAIV lots vs. $2 \%$ in placebo) and chills following the second dose (2 to $8 \%$ LAIV lots vs. $0 \%$ in placebo). After the second dose of LAIV or placebo the likelihood of any reactogenicity event decreased compared to the first dose. ${ }^{(66)}$ 
Tam et al. ${ }^{(41)}$ conducted a randomized, placebo-controlled LAIV trial for healthy children 12-36 months. Solicited reactogenicity events during the observation period days $0-11$, in year 1 following dose 1, identified significantly more LAIV recipients reporting fever $\left(>37.5^{\circ} \mathrm{C}\right)(22 \%$ vs. $17.6 \% \mathrm{p}=0.004)$, runny nose / nasal congestion $(62 \%$ vs $52 \% \mathrm{p}<0.001)$, decreased appetite $(24.2 \%$ vs $19.7 \%$ $p=0.003)$, decreased activity (13.4\% vs $10.7 \% p=0.026)$ and use of fever medication (21.3\% vs. $18.4 \% p=0.044)$. Following dose 2 the only significant difference was for runny nose / nasal congestion ( $49.8 \%$ vs $45.6 \% \mathrm{p}=0.03$ ). Similar results were also found in year 2 . Fever was the only unsolicited $A E$ reported which was significantly greater among LAIV recipients, $p=0.003$ and $p=0.017$, in year 1 and 2 respectively. A similar number of SAE was reported across study arms. ${ }^{(41)}$

In the placebo-controlled, LAIV trial by Mendelman et al., among healthy children 1-8 years, the largest absolute difference between the LAIV and placebo study arms was 9.5\% for runny nose/ nasal congestion, which was greater among the placebo group. All other differences for reactogenicity events between study arms were $<5 \%$. 67 )

As described above, passive surveillance systems, such as VAERS in the US and CAEFISS in Canada, can provide important safety signals, but the size of the population at risk cannot be determined and therefore it is not possible to estimate the incidence of adverse vaccine events or establish causal relationships.

In Canada, from 2000/2001 to 2011/2012, there were no LAIV related adverse events for children 2 to $<6$ years of age reported to CAEFISS.

In a follow-up analysis on data from the VAERS, October 2007-April 2009, adverse event reports in children 24-59 months of age were assessed. ${ }^{(68)}$ After over 10 million doses distributed to people of all ages, there were 222 relevant reports in children. Of the 222 reports the most frequently reported adverse events included fever (47\%), vomiting (28\%) and rhinitis (21\%). Six reports identified asthma exacerbation in children with a history of asthma, and eight reports identified wheezing in children without a history of asthma. No serious adverse events, such as death, anaphylaxis, Guillain-Barre Syndrome, or encephalitis were reported.

\section{I.5.3 Studies Including Both Trivalent Inactivated and Live Attenuated Influenza Vaccines}

As indicated above, in three of the randomized controlled trials reviewed, ${ }^{(37)(39)(54)}$ both LAIV and TIV study arms were included. Additionally, in the integrated analysis of LAIV randomized controlled trials by Ambrose et al., both TIV and placebo-controlled studies were included (see section 1.5.2 above for a review of the placebocontrolled LAIV studies).

In an open label, randomized, active controlled study by Ashkenazi et al., among participants 6-71 months with recurrent respiratory tract infections, the mean age (standard deviation (SD)) of participants was 38.1 (17.4) months and 39.9 (17.2) months for the LAIV and TIV study groups, respectively. The most frequently reported reactogenicity events following dose 1 (LAIV study arm vs. TIV study arm) included runny nose / nasal congestion (68.3\% vs. $55.1 \%$; $p<0.001)$, cough ( $44.2 \%$ vs. $44.1 \%$ ), decreased appetite $(29.5 \%$ vs. $26.8 \%)$, irritability ( $25.5 \%$ vs. $22.9 \%$ ), and fever $>37.5^{\circ} \mathrm{C}$ ( $23.5 \%$ vs. $21.4 \%$ ). These were also the most frequently reported events following dose 2 , but with a lower number of reports for each type of reactogenicity event. The only significant differences in reactogenicity events between the LAIV and TIV study groups were runny nose / nasal congestion following dose 1 (LAIV study arm $68.3 \%$ vs TIV study arm $55.1 \%, p=0.000$ ) and dose 2 (LAIV study arm $52.1 \%$ vs TIV study arm $44.4 \%$, $\mathrm{p}=0.001$ ) and decreased appetite following dose 2 (LAIV study arm $23.9 \%$ vs TIV study arm $19.8 \%, p=0.031$ ). For $A E$ following dose 1 , rhinitis was reported more frequently among the LAIV study arm, $8.7 \%$ vs $5.3 \%(p=0.002)$. For AE following dose 2 , rhinitis and otitis media were reported more frequently among the LAIV study arm, $6.1 \%$ versus $3.8 \%(p=0.021)$ and $3.7 \%$ versus $1.8 \%(p=0.011)$ respectively. The authors also reported that the incidence of first episode of wheezing was similar across study groups and doses, ranging from $12.3 \%$ to $13.8 \%$. During the trial, four serious adverse events (SAE) potentially related to study vaccines were reported among TIV recipients and 2 were reported among the LAIV study group, with no fatalities occurring.

In the randomized, TIV-controlled LAIV trial by Belshe et al., ${ }^{(39)}$ among children 6 to 59 months of age without a recent history of wheezing illness or severe asthma, $52.5 \%$ of participants were between $24-59$ months of age. During the study, fever $\left(>37.8^{\circ} \mathrm{C}\right)$ was found more 
frequently in the LAIV compared to the TIV study arm, $5.4 \%$ vs $2.0 \%$ ( $p<0.001$ ), following dose 1 , with no significant difference found after the second dose. The authors also found that a greater proportion of participants experienced pain, redness and swelling at the injection site in the TIV compared to the group which received LAIV and an intramuscular placebo. In a sub-group analysis of children 12-59 months of age similar rates of hospitalization, SAE and medically significant wheezing were found between study groups. Among participants 24-59 months vaccinated with LAIV or TIV, the rates of medically significant wheezing among previously unvaccinated children were similar between groups, with no ICU admissions, mechanical ventilation or deaths reported.

Neuzil et al. completed an analysis of data from a randomized, active-controlled, double blind trial which occurred from 1985-1990 among children 1 to 16 years of age in the US. The study vaccines included a TIV containing $A$ and $B$ strains, an attenuated cold-adapted influenza $A$ vaccine, and an inactivated influenza $B$ vaccine as the control. Among children 1 to 6 years of age, the rate of local (redness, and induration) and systemic (fever $\geq 37.8^{\circ} \mathrm{C}$, cough, coryza and sore throat) reactions were similar across study arms. Of the children 1 to 6 years of age who received TIV, 3\% (95\% Cl: 1.2-6.7) were reported to have had redness at the injection site, and $6 \%(95 \% \mathrm{Cl}: 3.3-10)$ had induration. The percentage of children among this age group reporting systemic reactions included 11.5\% (95\% Cl:7.6-17) for fever, 8.5\%(95\%Cl: 5.2-13) for cough, $16 \%(95 \% \mathrm{Cl}: 11-22)$ for coryza and $4 \%(95 \% \mathrm{Cl}: 1.9-8.0)$ for sore throat. Rates of systemic reactogenicity events (fever, cough, coryza and sore throat) were also found to be similar in all age groups ( 1 to $<6$ years, 6 to $<11$ years and 11 to $<16$ years of age) and across study years 2 to 5 .
Ambrose et al. ${ }^{(38)}$ completed an integrated analysis of LAIV randomized controlled trials of children 2 to 17 years, using both TIV and placebo-controlled studies. Among the TIV-controlled trials they found a similar frequency of events between the LAIV and TIV study arms, with an LAIV and TIV incidence following dose 1 of around $45 \%$ for cough, $15 \%$ for decreased appetite, $14 \%$ for irritability, $13 \%$ for abdominal pain, $14 \%$ for decreased activity/ tiredness, $15 \%$ for headache, $6 \%$ for vomiting, $15 \%$ for sore throat and $6 \%$ for chills. Ambrose et al. also found that the frequency of muscle aches reported after dose 1 was significantly lower among those in the LAIV compared to the TIV group $(p=0.04)$. For runny/stuffy nose there were more reports among those immunized with LAIV compared to the TIV study arms, with an absolute rate difference of $11.8 \%$ after dose 1 and $4.1 \%$ after dose 2 ( $p<0.01$ for both). The authors found similar rates of any SAE between TIV and LAIV groups (observation period day $0-42$ ), $0.75 \%$ and $1.01 \%$ respectively. The proportion of any SAE was also similar between vaccine groups when the observation period was extended to day 180 . For children aged 24-35 months, when analyzed by subject region and gender, the patterns of reactogenicity events, AEs, and SAE were consistent with those observed in the overall population. ${ }^{(38)}$ 


\section{I.6 TABLES}

TABLE 2: Levels of evidence based on research design

\begin{tabular}{l|l}
\hline I & Evidence from randomized controlled trial(s). \\
\hline II-1 & Evidence from controlled trial(s) without randomization. \\
\hline $\mathbf{I I - 2}$ & $\begin{array}{l}\text { Evidence from cohort or case-control analytic studies, preferably from more than one centre or research group using clinical } \\
\text { outcome measures of vaccine efficacy. }\end{array}$ \\
\hline $\mathbf{I I - 3}$ & $\begin{array}{l}\text { Evidence obtained from multiple time series with or without the intervention. Dramatic results in uncontrolled experiments } \\
\text { (such as the results of the introduction of penicillin treatment in the 1940s) could also be regarded as this type of evidence. } \\
\text { Opinions of respected authorities, based on clinical experience, descriptive studies and case reports, or reports of } \\
\text { expert committees. }\end{array}$ \\
\hline
\end{tabular}

TABLE 3: Quality (internal validity) rating of evidence

\begin{tabular}{l|l}
\hline Good & A study (including meta-analyses or systematic reviews) that meets all design- specific criteria* well. \\
\hline Fair & $\begin{array}{l}\text { A study (including meta-analyses or systematic reviews) that does not meet (or it is not clear that it meets) at least one } \\
\text { design-specific criterion* but has no known "fatal flaw". }\end{array}$ \\
\hline Poor & $\begin{array}{l}\text { A study (including meta-analyses or systematic reviews) that has at least one design-specific* "fatal flaw", or an accumulation } \\
\text { of lesser flaws to the extent that the results of the study are not deemed able to inform recommendations. }\end{array}$ \\
\hline I & $\begin{array}{l}\text { NACl concludes that there is insufficient evidence (in either quantity and/or quality) to make a recommendation, } \\
\text { however other factors may influence decision-making. }\end{array}$ \\
\hline
\end{tabular}

* General design specific criteria are outlined in Harris et al., 20011.

\section{TABLE 4: NACl recommendation for immunization - Grades}

\begin{tabular}{l|l}
\hline A & $\mathrm{NACl}$ concludes that there is good evidence to recommend immunization. \\
\hline B & $\mathrm{NACl}$ concludes that there is fair evidence to recommend immunization. \\
\hline C & $\begin{array}{l}\mathrm{NACl} \text { concludes that the existing evidence is conflicting and does not allow making a recommendation for or against } \\
\text { immunization; however other factors may influence decision-making. }\end{array}$ \\
\hline D & $\mathrm{NACl}$ concludes that there is fair evidence to recommend against immunization. \\
\hline E & $\mathrm{NACl}$ concludes that there is good evidence to recommend against immunization. \\
\hline I & $\begin{array}{l}\text { NACl concludes that there is insufficient evidence (in either quantity and/or quality) to make a recommendation, } \\
\text { however other factors may influence decision-making. }\end{array}$ \\
\hline
\end{tabular}

Harris RP, Helfand M, Woolf SH, et al. Current methods of the US Preventive Services Task Force: a review of the process. Am J Prev Med 2001;20:21-35. 
TABLE 5A: Evidence tables for children 24 to 59 months of age - Evidence related to TIV efficacy/effectiveness

\begin{tabular}{|c|c|c|c|c|c|c|}
\hline \multicolumn{5}{|c|}{ EVIDENCE RELATED TO TIV EFFICACY/EFFECTIVENESS } & \multirow[b]{2}{*}{$\begin{array}{l}\text { Level of } \\
\text { Evidence }\end{array}$} & \multirow[b]{2}{*}{ Quality } \\
\hline Study & Vaccine & Study Design & Participants & $\begin{array}{l}\text { Summary of Key Findings } \\
\text { Using Text or Data }\end{array}$ & & \\
\hline $\begin{array}{l}\text { Belongia EA, } \\
\text { Kieke BA, } \\
\text { Donahue JG, } \\
\text { Coleman LA, } \\
\text { Irving SA, } \\
\text { Meece JK, } \\
\text { et al. Influenza } \\
\text { vaccine } \\
\text { effectiveness } \\
\text { in Wisconsin } \\
\text { during the } \\
2007-08 \text { season: } \\
\text { comparison } \\
\text { of interim and } \\
\text { final results. } \\
\text { Vaccine } \\
2011 \text { Sep } \\
\text { 2;29(38): } \\
6558-6563 .(25)\end{array}$ & $\begin{array}{l}\text { TIV } \\
\text { Lineage } \\
\text { mismatch } \\
\text { for type B } \\
\text { viruses during } \\
\text { this season } \\
\text { Children <9yrs } \\
\text { fully vaccinated: } \\
\text { 1. Two doses, } \\
\text { or } \\
\text { 2. One dose } \\
\text { and } \geq 1 \text { dose } \\
\text { received in a } \\
\text { prior season }\end{array}$ & $\begin{array}{l}\text { Prospective } \\
\text { community } \\
\text { cohort with } \\
\text { case-control } \\
\text { analyses } \\
2007 / 08 \text { season } \\
\text { US }\end{array}$ & $\begin{array}{l}\mathrm{N}=1,914 \\
\text { Residents 6mos } \\
\text { to 65+yrs with } \\
\text { continuous } \\
\text { residency for at } \\
\text { least } 12 \text { months } \\
\text { (or since birth) } \\
\text { 14\% of all cases } \\
\text { and } 20 \% \text { of all } \\
\text { controls with } \\
\text { high risk } \\
\text { condition } \\
\text { 6-59mos } \\
\mathrm{n}_{\text {cases }}=118 \\
\mathrm{n}_{\text {controls }}=294 \\
\text { Vaccination } \\
\text { status obtained } \\
\text { by electronic } \\
\text { records; } \\
\text { partially } \\
\text { immunized } \\
\text { children } \\
\text { excluded } \\
\text { Enrolled } \\
\text { through } \\
\text { in-patient or } \\
\text { out patient } \\
\text { medical } \\
\text { encounter }\end{array}$ & $\begin{array}{l}\text { Outcome: Medically attended, } \\
\text { laboratory confirmed influenza } \\
\text { (rRT-PCR and viral culture) } \\
\text { Cases: Laboratory confirmed } \\
\text { positive influenza } \\
\text { Controls: Laboratory confirmed } \\
\text { negative influenza } \\
\text { Vaccine effectiveness: } \\
\text { All participants (6-59 months of age) } \\
\text { Unadjusted: } 40 \% \\
\text { Adjusted: } 39 \% \text { (2, 62) } \\
\text { Participants tested 0-3 days after } \\
\text { illness onset (6-59 months of age) } \\
\text { Unadjusted: } 32 \% \\
\text { Adjusted: } 31 \% \text { (-24, 62) } \\
\text { Adjusted for age, week of enrolment, } \\
\text { presence of high risk medical } \\
\text { condition }\end{array}$ & Level II-2 & Good \\
\hline
\end{tabular}




\begin{tabular}{|c|c|c|c|c|c|c|}
\hline \multicolumn{5}{|c|}{ EVIDENCE RELATED TO TIV EFFICACY/EFFECTIVENESS } & \multirow[b]{2}{*}{$\begin{array}{l}\text { Level of } \\
\text { Evidence }\end{array}$} & \multirow[b]{2}{*}{ Quality } \\
\hline Study & Vaccine & Study Design & Participants & $\begin{array}{l}\text { Summary of Key Findings } \\
\text { Using Text or Data }\end{array}$ & & \\
\hline $\begin{array}{l}\text { Dixon GA, } \\
\text { Moore HC, } \\
\text { Kelly H, et al. } \\
\text { Lessons from } \\
\text { the first year } \\
\text { of the } \\
\text { WAIVE study } \\
\text { investigating } \\
\text { the protective } \\
\text { effect of } \\
\text { influenza } \\
\text { vaccine against } \\
\text { laboratory- } \\
\text { confirmed } \\
\text { influenza in } \\
\text { hospitalised } \\
\text { children aged } \\
\text { 6-59 months. } \\
\text { Influenza other } \\
\text { respi viruses } \\
2010 \text { Jul;4(4): } \\
231-234 .(27)\end{array}$ & $\begin{array}{l}\text { TIV } \\
0.5 \mathrm{ml} \text { for } \\
\text { children } \geq 3 y r s ; \\
0.25 \mathrm{ml} \text { for } \\
\text { children } 6 \\
\text { months to } \\
<3 y r s \\
\text { Fully vaccinated } \\
\text { (All doses } \\
\text { received }>14 \\
\text { days prior } \\
\text { to ILI onset): } \\
\text { 1. Two doses } \\
\geq 21 \text { days apart, } \\
\text { or } \\
\text { 2. One dose, } \\
\text { and } \geq 2 \text { doses } \\
\text { received in any } \\
\text { previous season }\end{array}$ & $\begin{array}{l}\text { Nested } \\
\text { case-control, } \\
\text { multi-site } \\
2008 \text { season } \\
\text { Australia }\end{array}$ & $\begin{array}{l}\mathrm{N}=76 \\
\mathrm{n}_{\text {case }}=26 \\
\mathrm{n}_{\text {control }}=50 \\
\text { Children } \\
6-59 \text { mos } \\
\text { (>2yrs }=52.6 \% \\
\text { of participants) }\end{array}$ & $\begin{array}{l}\text { Case: Hospital admission with } \\
\text { laboratory confirmed influenza } \\
\text { (culture only or culture and } \\
\text { RT-PCR if culture negative) } \\
\text { Control: Hospital admission for } \\
\text { non-acute respiratory illness; matched } \\
\text { for age and Aboriginal/Torres Strait } \\
\text { Islander status } \\
\text { Adjusted efficacy in fully vaccinated } \\
\text { to unvaccinated children } 83 \% \text { (-54, 98) } \\
\text { Adjusted for sex, presence of } \\
\text { comorbidities, pre-term birth }\end{array}$ & Level II-2 & $\begin{array}{l}\text { Fair } \\
\text { Small } \\
\text { numbers }\end{array}$ \\
\hline
\end{tabular}




\begin{tabular}{|c|c|c|c|c|c|c|}
\hline \multicolumn{5}{|c|}{ EVIDENCE RELATED TO TIV EFFICACY/EFFECTIVENESS } & \multirow[b]{2}{*}{$\begin{array}{l}\text { Level of } \\
\text { Evidence }\end{array}$} & \multirow[b]{2}{*}{ Quality } \\
\hline Study & Vaccine & Study Design & Participants & $\begin{array}{l}\text { Summary of Key Findings } \\
\text { Using Text or Data }\end{array}$ & & \\
\hline $\begin{array}{l}\text { Eisenberg KW, } \\
\text { Szilagyi PG, } \\
\text { Fairbrother G, } \\
\text { et al. Vaccine } \\
\text { effectiveness } \\
\text { against } \\
\text { laboratory- } \\
\text { confirmed } \\
\text { influenza in } \\
\text { children } 6 \text { to } \\
59 \text { months of } \\
\text { age during } \\
\text { the 2003-2004 } \\
\text { and 2004-2005 } \\
\text { influenza } \\
\text { seasons. } \\
\text { Pediatrics } \\
\text { 2008;122(5): } \\
\text { 911-919.(20) }\end{array}$ & $\begin{array}{l}\text { Unspecified, } \\
\text { TIV most likely } \\
\text { as LAIV not } \\
\text { yet approved } \\
\text { for use in } \\
\text { participant } \\
\text { age range } \\
\text { Full vaccination } \\
\text { (All doses } \\
\text { received } \geq 14 \\
\text { days prior } \\
\text { to ILI onset): } \\
\text { 1. Two doses } \\
\geq 24 \text { days apart, } \\
\text { or } \\
\text { 2. One dose, } \\
\text { and } \geq 1 \text { dose } \\
\text { received in } \\
\text { previous season }\end{array}$ & $\begin{array}{l}\text { Case control, } \\
\text { prospective } \\
\text { multi-site } \\
2003 / 04 \\
2004 / 05 \\
\text { seasons }\end{array}$ & $\begin{array}{l}2003 / 04 \\
N=972 \\
n_{\text {case }}=228 \\
n_{\text {control }}=744 \\
2004 / 05 \\
N=1502 \\
n_{\text {case }}=197 \\
n_{\text {control }}=1305 \\
\text { Children } \\
\text { 6-59mos } \\
\text { 31\% (2003/04) } \\
\text { and 27\% } \\
\text { (2004/05) of } \\
\text { participants } \\
\text { with high risk } \\
\text { conditions } \\
\text { (e.g., asthma, } \\
\text { cancer, heart } \\
\text { disease, cystic } \\
\text { fibrosis, etc.) } \\
\text { In-patient and } \\
\text { out-patient } \\
\text { recruitment }\end{array}$ & $\begin{array}{l}\text { Exposure of interest: Influenza } \\
\text { vaccination ascertained by contacting } \\
\text { participant's primary care provider } \\
\text { with medical record confirmation } \\
\text { Case: Acute respiratory illness or } \\
\text { fever with } 1 \text { positive viral culture } \\
\text { (in-patient population only) or } 2 \\
\text { positive RT-PCR assays } \\
\text { Control: Acute respiratory illness or } \\
\text { fever with negative viral culture or } \\
\text { RT-PCR assays; frequency matched } \\
\text { by site, visit setting, date of study } \\
\text { enrolment (control) or influenza } \\
\text { symptom onset (case) } \\
\text { Vaccine effectiveness: } \\
\text { 2003/04 } \\
\text { Fully vaccinated: } 63 \text { (16,84) } \\
\text { Partially vaccinated: } 38 \text { (-53, 75) } \\
\text { Fully vaccinated: } 66 \text { (-106, 94) } \\
\text { Partially vaccinated: } 33 \text { (-109, 78) } \\
\text { between partially vaccinated and } \\
\text { unvaccinated individuals. }\end{array}$ & Level II-2 & $\begin{array}{l}\text { Good } \\
\text { Low } \\
\text { numbers } \\
\text { of fully } \\
\text { vaccin- } \\
\text { ated } \\
\text { children } \\
\text { in 2003/04 } \\
\text { make } \\
\text { vaccine } \\
\text { efficacy } \\
\text { difficult to } \\
\text { interpret }\end{array}$ \\
\hline
\end{tabular}




\begin{tabular}{|c|c|c|c|c|c|c|}
\hline \multicolumn{5}{|c|}{ EVIDENCE RELATED TO TIV EFFICACY/EFFECTIVENESS } & \multirow[b]{2}{*}{$\begin{array}{l}\text { Level of } \\
\text { Evidence }\end{array}$} & \multirow[b]{2}{*}{ Quality } \\
\hline Study & Vaccine & Study Design & Participants & $\begin{array}{l}\text { Summary of Key Findings } \\
\text { Using Text or Data }\end{array}$ & & \\
\hline $\begin{array}{l}\text { Fujieda M, } \\
\text { Maeda A, } \\
\text { Kondo K, } \\
\text { et al. Influenza } \\
\text { vaccine } \\
\text { effectiveness } \\
\text { and con- } \\
\text { founding } \\
\text { factors among } \\
\text { young children. } \\
\text { Vaccine } \\
2008 ; 26(50): \\
6481-6485 .{ }^{(33)}\end{array}$ & $\begin{array}{l}\text { TIV } \\
2 \text { doses } 2-4 \\
\text { weeks apart; } \\
0.1 \mathrm{ml} \text { for } \\
\text { children <1yr, } \\
0.2 \mathrm{ml} \text { for } \\
\text { children } \geq 1 \mathrm{yr}\end{array}$ & $\begin{array}{l}\text { Cohort study, } \\
\text { multi-centre } \\
\text { 2002/03 season } \\
\text { Japan }\end{array}$ & $\begin{array}{l}\mathrm{N}=2,913 \\
\mathrm{n}_{\text {vaccinated }}= \\
1512 \\
\mathrm{n}_{\text {unvaccinated }}= \\
1401 \\
\text { Children <6yrs } \\
\text { Paediatric clinic } \\
\text { recruitment }\end{array}$ & $\begin{array}{l}\text { Primary outcome: ILI (acute febrile } \\
\text { illness that occurred during the highest } \\
\text { epidemic period of influenza in each } \\
\text { study area; highest temperature of } \\
\text { child reported for each week) } \\
\text { Adjusted for factors including: } \\
\text { vaccination status, age group, number } \\
\text { of siblings, physician visits for cold } \\
\text { symptoms with the last } 6 \text { months, } \\
\text { preschool attendance, and vaccine } \\
\text { dosage (<2.0 years analysis only) for } \\
\text { temperature outcomes ( }<38.0, \\
\left.38.0-38.9, \geq 39.0^{\circ} \mathrm{C}\right) \\
\text { Vaccine effectiveness (adjusted) } \\
2.0-3.9 \text { yrs: } 41 \%(26,53 \%) \\
4.0-5.9 \text { yrs: } 25 \%(2,42 \%) \\
\text { Adjusted OR: } \\
2.0-3.9 \text { yrs: } 0.59(0.47,0.74) ; p<0.001 \\
4.0-5.9 \text { yrs: } 0.75(0.58,0.98) ; p=0.034\end{array}$ & Level II-2 & $\begin{array}{l}\text { Fair } \\
\text { Vac- } \\
\text { cination } \\
\text { was } \\
\text { self- } \\
\text { selected } \\
\text { by } \\
\text { parents } \\
\text { introdu- } \\
\text { cing } \\
\text { con- } \\
\text { founders } \\
\text { that may } \\
\text { not have } \\
\text { been } \\
\text { con- } \\
\text { sidered }\end{array}$ \\
\hline $\begin{array}{l}\text { Fujieda M, } \\
\text { Maeda A, } \\
\text { Kondo K, et al. } \\
\text { Inactivated } \\
\text { influenza } \\
\text { vaccine } \\
\text { effectiveness in } \\
\text { children under } \\
6 \text { years of age } \\
\text { during the } \\
\text { 2002-2003 } \\
\text { season. Vaccine } \\
\text { 2006;24(7): } \\
957-963 .{ }^{(34)}\end{array}$ & $\begin{array}{l}\text { TIV } \\
2 \text { doses } 2-4 \\
\text { weeks apart; } \\
0.1 \mathrm{ml} \text { for } \\
\text { children <1yr, } \\
0.2 \mathrm{ml} \text { for } \\
\text { children } \geq 1 \mathrm{yr}\end{array}$ & $\begin{array}{l}\text { Cohort study, } \\
\text { multi-centre } \\
\text { 2002/03 season } \\
\text { Japan }\end{array}$ & $\begin{array}{l}\mathrm{N}=2,913 \\
\mathrm{n}_{\text {vaccinated }}= \\
1512 \\
\mathrm{n}_{\text {unvaccinated }}=1 \\
401\end{array}$ & $\begin{array}{l}\text { Primary outcome: ILI (acute febrile } \\
\text { illness that occurred during the highest } \\
\text { epidemic period of influenza in each } \\
\text { study area; highest temperature of } \\
\text { child reported for each week) } \\
\text { Adjusted for factors including: } \\
\text { vaccination status, age, siblings, } \\
\text { physician visits for cold symptoms } \\
\text { with in the last } 6 \text { months, preschool } \\
\text { attendance, disease onset during } \\
\text { the previous influenza season } \\
\text { Vaccine effectiveness (adjusted) } \\
2.0-5.9 \text { yrs: } 33 \%(21,44 \%) \\
\text { Adjusted OR: } \\
2.0-5.9 \text { yrs: } 0.67(0.56,0.79) ; p<0.001 \\
2.0-2.9 \text { yrs: } 0.61(0.44,0.84) ; p=0.002 \\
3.0-3.9 \text { yrs: } 0.60 \text { ( } 0.43,0.84) ; p=0.003 \\
4.0-4.9 \text { yrs: } 0.72(0.50,1.03) ; p=0.071\end{array}$ & Level II-2 & $\begin{array}{l}\text { Fair } \\
\text { Vac- } \\
\text { cination } \\
\text { was } \\
\text { self- } \\
\text { selected } \\
\text { by } \\
\text { parents } \\
\text { introdu- } \\
\text { cing } \\
\text { con- } \\
\text { founders } \\
\text { that may } \\
\text { not have } \\
\text { been } \\
\text { con- } \\
\text { sidered }\end{array}$ \\
\hline
\end{tabular}




\begin{tabular}{|c|c|c|c|c|c|c|}
\hline \multicolumn{5}{|c|}{ EVIDENCE RELATED TO TIV EFFICACY/EFFECTIVENESS } & \multirow[b]{2}{*}{$\begin{array}{l}\text { Level of } \\
\text { Evidence }\end{array}$} & \multirow[b]{2}{*}{ Quality } \\
\hline Study & Vaccine & Study Design & Participants & $\begin{array}{l}\text { Summary of Key Findings } \\
\text { Using Text or Data }\end{array}$ & & \\
\hline $\begin{array}{l}\text { Ghendon YZ, } \\
\text { Kaira AN, et al. } \\
\text { The effect of } \\
\text { mass influenza } \\
\text { immunization } \\
\text { in children on } \\
\text { the morbidity } \\
\text { of the } \\
\text { unvaccinated } \\
\text { elderly. } \\
\text { Epidemiol } \\
\text { Infect 2006 } \\
\text { Feb;134(1): } \\
71-78 .{ }^{(32)}\end{array}$ & $\begin{array}{l}\text { TIV }\left(\text { Influvac }{ }^{\circledR}\right) \\
\text { Good antigenic } \\
\text { match between } \\
\text { vaccine and } \\
\text { circulating A/ } \\
\text { H3N2 and } \\
\text { B strains in } \\
\text { study area } \\
0.5 m L \text {, single } \\
\text { dose only } \\
\text { One dose for } \\
\text { children }>3 y r s\end{array}$ & $\begin{array}{l}\text { Community- } \\
\text { based cohort } \\
\text { study, multi- } \\
\text { region (four } \\
\text { communities: } \\
\text { two target, two } \\
\text { comparison) } \\
\text { Mass } \\
\text { vaccination in } \\
\text { school-aged } \\
\text { children in } \\
\text { target } \\
\text { communities } \\
2001 / 02 \text { season } \\
\text { Russia }\end{array}$ & 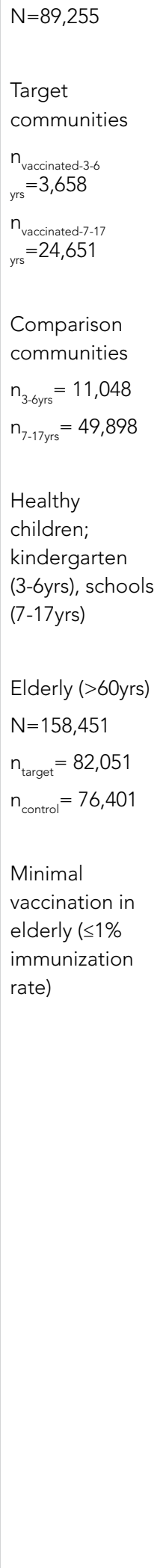 & 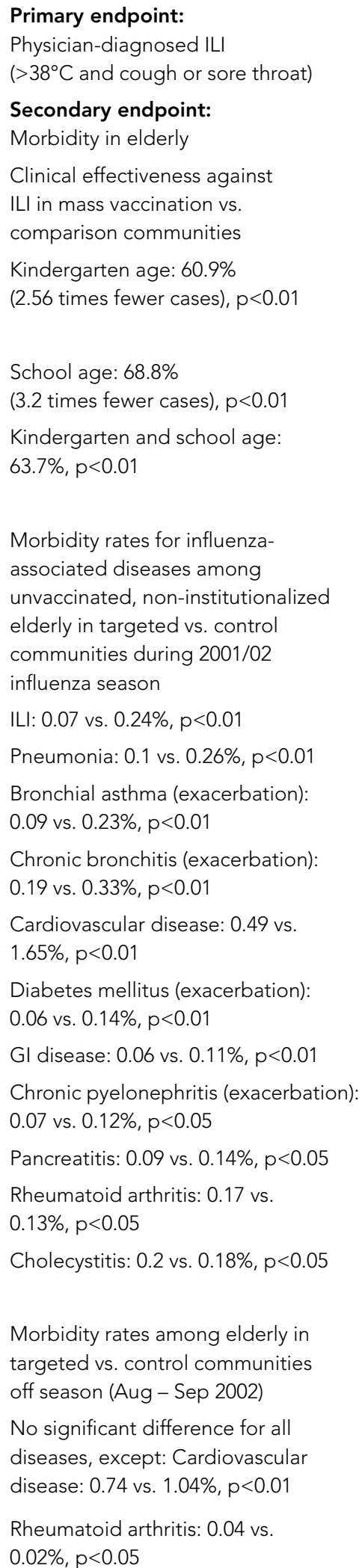 & Level II-2 & $\begin{array}{l}\text { Fair } \\
\text { Target } \\
\text { commun- } \\
\text { ities had } \\
\text { slightly } \\
\text { higher } \\
\text { baseline } \\
\text { incidence } \\
\text { of ILI }\end{array}$ \\
\hline
\end{tabular}




\begin{tabular}{|c|c|c|c|c|c|c|}
\hline \multicolumn{5}{|c|}{ EVIDENCE RELATED TO TIV EFFICACY/EFFECTIVENESS } & \multirow[b]{2}{*}{$\begin{array}{l}\text { Level of } \\
\text { Evidence }\end{array}$} & \multirow[b]{2}{*}{ Quality } \\
\hline Study & Vaccine & Study Design & Participants & $\begin{array}{l}\text { Summary of Key Findings } \\
\text { Using Text or Data }\end{array}$ & & \\
\hline $\begin{array}{l}\text { Heinonen } \mathrm{S} \text {, } \\
\text { Silvennoinen } \mathrm{H} \text {, } \\
\text { Lehtinen } \mathrm{P} \text {, et } \\
\text { al. Effectiveness } \\
\text { of inactivated } \\
\text { influenza } \\
\text { vaccine in } \\
\text { children aged } \\
9 \text { months to } \\
3 \text { years: an } \\
\text { observational } \\
\text { cohort study. } \\
\text { Lancet Infect } \\
\text { Dis 2011;11(1): } \\
23-29.26) \\
\text { NCT005935023 }\end{array}$ & $\begin{array}{l}\text { TIV (Vaxigrip }{ }^{\mathrm{TM}} \text { ) } \\
0.5 \mathrm{ml} \text { doses } \\
\text { (one dose, or } \\
\text { two doses four } \\
\text { weeks apart if } \\
\text { vaccine naïve) } \\
\text { A strains } \\
\text { well-matched, } \\
\text { but B strain } \\
\text { poorly matched } \\
\text { to circulating } \\
\text { strains }\end{array}$ & $\begin{array}{l}\text { Prospective } \\
\text { cohort } \\
\text { 2007/08 season } \\
\text { Finland }\end{array}$ & $\begin{array}{l}\mathrm{N}=631 \\
\mathrm{n}=278 \\
(9-23 \mathrm{mos}) \\
\mathrm{n}=353 \\
(24-40 \mathrm{mos}) \\
\\
\text { Children } \\
\text { 9mos-3yrs }\end{array}$ & $\begin{array}{l}\text { Primary outcome: Symptomatic } \\
\text { laboratory-confirmed influenza (by } \\
\text { time-resolved fluoroimmunoassay, } \\
\text { viral culture, immunoperoxidase } \\
\text { staining with monoclonal antibodies, } \\
\text { and/or RT-PCR) } \\
\text { Vaccine effectiveness } \\
\text { 2-3 yrs } \\
\text { Influenza A: } 100 \% \text { (6, 100); } p=0.05 \\
\text { Influenza B: } 33 \%(-97,78) ; p=0.78 \\
\text { Any strain: } 63 \% \text { (-5, 88); } p=0.06 \\
\text { Case-control analysis by age group } \\
\text { (partially vaccinated individuals } \\
\text { considered unvaccinated) } \\
\text { Case: Provided at least one sample } \\
\text { with influenza identified during the } \\
\text { duration of study } \\
\text { Control: Provided samples where } \\
\text { influenza was not identified } \\
\text { Influenza A: } 100 \% \text { ( } 4,100) \\
\text { Influenza B: } 38 \% \text { (-121, 83) } \\
\text { Any strain: } 71 \% \text { (-1, } 92) \\
\text { Vaccine effectiveness }\end{array}$ & Level II-2 & $\begin{array}{l}\text { Fair } \\
\text { Voluntary } \\
\text { study } \\
\text { enrol- } \\
\text { ment, } \\
\text { but } \\
\text { compari- } \\
\text { son } \\
\text { groups } \\
\text { are similar }\end{array}$ \\
\hline
\end{tabular}




\begin{tabular}{|c|c|c|c|c|c|c|}
\hline \multicolumn{5}{|c|}{ EVIDENCE RELATED TO TIV EFFICACY/EFFECTIVENESS } & \multirow[b]{2}{*}{$\begin{array}{l}\text { Level of } \\
\text { Evidence }\end{array}$} & \multirow[b]{2}{*}{ Quality } \\
\hline Study & Vaccine & Study Design & Participants & $\begin{array}{l}\text { Summary of Key Findings } \\
\text { Using Text or Data }\end{array}$ & & \\
\hline $\begin{array}{l}\text { Hoen AG, } \\
\text { Buckeridge DL, } \\
\text { Charland KM, } \\
\text { et al. Effect of } \\
\text { expanded US } \\
\text { recommenda- } \\
\text { tions for } \\
\text { seasonal } \\
\text { influenza } \\
\text { vaccination: } \\
\text { comparison of } \\
\text { two pediatric } \\
\text { emergency } \\
\text { departments } \\
\text { in the United } \\
\text { States and } \\
\text { Canada. CMAJ } \\
\text { 2011;183(13): } \\
\text { E1025-32.(35) }\end{array}$ & $\begin{array}{l}\text { TIV (Canada) } \\
\text { Individual } \\
\text { vaccination } \\
\text { status } \\
\text { unavailable; } \\
\text { Vaccination } \\
\text { coverage } \\
\text { estimated from } \\
\text { national surveys } \\
\text { TIV/LAIV (US) }\end{array}$ & $\begin{array}{l}\text { Ecological } \\
2000 / 01 \text { to } \\
2008 / 09 \\
\text { seasons } \\
2 \text { sites: } \\
\text { Montréal, } \\
\text { Canada \& } \\
\text { Boston, US }\end{array}$ & $\begin{array}{l}\mathrm{N}=114,657 \text { ILI } \\
\text { visits / } \\
1,043,989 \text { total } \\
\text { visits } \\
\text { Children } \\
0-18 y r s \\
\text { Emergency } \\
\text { department } \\
\text { visits }\end{array}$ & $\begin{array}{l}\text { Primary outcome: Emergency } \\
\text { department visits related to ILI (before } \\
\text { and after } 2006 \text { US policy change to } \\
\text { recommend influenza vaccination in } \\
\text { children } 2 \text { to }<5 \text { yrs) } \\
\text { Decline of rate of emergency visits in } \\
\text { US site compared to Canadian site: } \\
\text { adjusted rate ratio } 0.66 \text { ( } 0.58,0.75) \\
11-18 \% \text { for non-target age groups } \\
\text { observed following policy change } \\
\text { in adjusted models, but not in } \\
\text { unadjusted models } \\
\text { Adjusted for seasonal and } \\
\text { virologic effects (composition } \\
\text { of circulating strains) }\end{array}$ & Level II-3 & $\begin{array}{l}\text { Poor } \\
\text { Vaccine } \\
\text { uptake is } \\
\text { estimated } \\
\text { from } \\
\text { surveys; } \\
\text { differ- } \\
\text { ences in } \\
\text { demo- } \\
\text { graphics } \\
\text { and } \\
\text { health } \\
\text { care } \\
\text { system } \\
\text { not } \\
\text { con- } \\
\text { sidered }\end{array}$ \\
\hline $\begin{array}{l}\text { Joshi AY, lyer } \\
\text { VN, St Sauver } \\
\mathrm{JL} \text {, et al. } \\
\text { Effectiveness } \\
\text { of inactivated } \\
\text { influenza } \\
\text { vaccine in } \\
\text { children less } \\
\text { than } 5 \text { years } \\
\text { of age over } \\
\text { multiple } \\
\text { influenza } \\
\text { seasons: a } \\
\text { case-control } \\
\text { study. Vaccine } \\
2009 \text { Jul } \\
\text { 16;27(33): } \\
4457-4461 .(21)\end{array}$ & $\begin{array}{l}\text { Vaccination } \\
\text { status obtained } \\
\text { by medical } \\
\text { records } \\
\text { Mismatch } \\
\text { between } \\
\text { vaccine and } \\
\text { circulating } \\
\text { strains: } \\
\text { A/H3N2 in } \\
01 / 02-04 / 05 \text {, } \\
06 / 07 ; \\
\text { A/H1N1 in } \\
99 / 00 \text {, } \\
01 / 02-03 / 04 ; \\
\text { B in 01/02, } \\
03 / 04,05 / 06, \\
06 / 07\end{array}$ & $\begin{array}{l}\text { 1999/2000- } \\
2006 / 07 \\
\text { seasons } \\
\text { US }\end{array}$ & $\begin{array}{l}N=206 \\
n_{\text {case }}=103 \\
n_{\text {control }}=103 \\
\text { Children } \\
6-59 \text { mos }\end{array}$ & $\begin{array}{l}\text { Case: Medically attended, laboratory } \\
\text { confirmed influenza illness with } \\
\text { available immunization information } \\
\text { Control: Test negative for influenza } \\
\text { with available immunization } \\
\text { information; age and sex-matched } \\
\text { Odds ratio (vaccinated vs. } \\
\text { unvaccinated) } \\
\text { Fully vaccinated: } 0.14(0.03,0.71) \\
\text { Partially vaccinated: } 0.27(0.07 \text {, } \\
0.97) ; \text { p=0.04 } \\
\text { Vaccine efficacy (vaccinated vs. } \\
\text { unvaccinated) } \\
\text { Fully vaccinated: } 86 \%(29,97) \\
\text { Partially vaccinated: } 73 \%(3,93) \\
\text { Number needed to treat: } 3-11 \text { children } \\
\text { (estimated attack rate of } 10-40 \%)\end{array}$ & Level II-2 & $\begin{array}{l}\text { Poor } \\
\text { Vaccine } \\
\text { uptake is } \\
\text { estimated } \\
\text { from } \\
\text { surveys; } \\
\text { differ- } \\
\text { ences in } \\
\text { demo- } \\
\text { graphics } \\
\text { and } \\
\text { health } \\
\text { care } \\
\text { system } \\
\text { not } \\
\text { con- } \\
\text { sidered }\end{array}$ \\
\hline
\end{tabular}




\begin{tabular}{|c|c|c|c|c|c|c|}
\hline \multicolumn{5}{|c|}{ EVIDENCE RELATED TO TIV EFFICACY/EFFECTIVENESS } & \multirow[b]{2}{*}{$\begin{array}{l}\text { Level of } \\
\text { Evidence }\end{array}$} & \multirow[b]{2}{*}{ Quality } \\
\hline Study & Vaccine & Study Design & Participants & $\begin{array}{l}\text { Summary of Key Findings } \\
\text { Using Text or Data }\end{array}$ & & \\
\hline $\begin{array}{l}\text { Katayose M, } \\
\text { Hosoya M, } \\
\text { Haneda T, } \\
\text { et al. The } \\
\text { effectiveness } \\
\text { of trivalent } \\
\text { inactivated } \\
\text { influenza } \\
\text { vaccine in } \\
\text { children over } \\
\text { six consecutive } \\
\text { influenza } \\
\text { seasons. } \\
\text { Vaccine } \\
2011 ; 29(9) \text { : } \\
\text { 1844-1849.(29) }\end{array}$ & $\begin{array}{l}\text { TIV } \\
\text { Two doses 3-4 } \\
\text { weeks apart } \\
\text { recommended } \\
\text { regardless of } \\
\text { previous receipt } \\
\text { of TIV } \\
0.1 \mathrm{ml} \text { for } \\
\text { children } \\
6-11 \mathrm{mos} ; 0.2 \mathrm{ml} \\
\text { for children } \\
1-<6 y r s\end{array}$ & $\begin{array}{l}\text { Prospective, } \\
\text { non- } \\
\text { randomized } \\
\text { observational } \\
\text { study } \\
\text { 2002/03- } \\
2007 / 08 \\
\text { seasons } \\
\text { Japan }\end{array}$ & $\begin{array}{l}\mathrm{N}=14,788 \\
\text { Vaccination } \\
\text { status prior to } \\
\text { subsequent } \\
\text { season: } \\
\mathrm{n}_{\text {fully vaccinated }} \\
=6,933 \\
\mathrm{n}_{\text {partially vaccinated }} \\
=887 \\
\mathrm{n}_{\text {unvaccinated }}=6, \\
968 \\
\text { Children } \\
6 \text { mos-<6yrs }\end{array}$ & 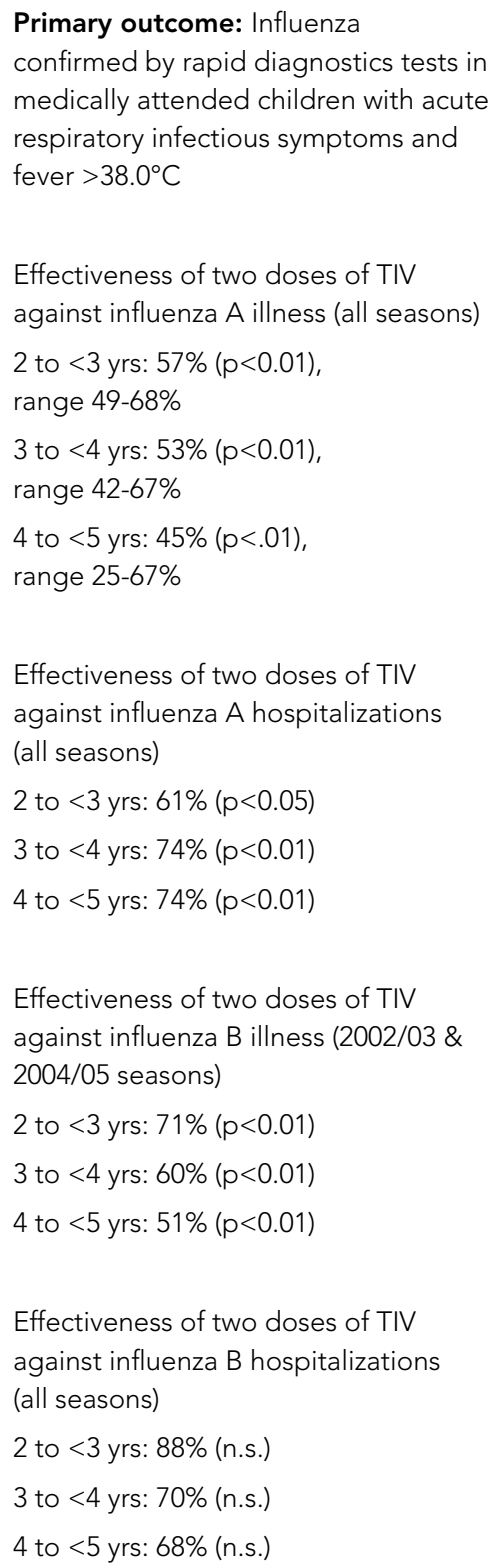 & Level II-3 & $\begin{array}{l}\text { Fair } \\
\text { Self- } \\
\text { selection } \\
\text { of } \\
\text { vaccina- } \\
\text { tion and } \\
\text { differ- } \\
\text { ences in } \\
\text { health } \\
\text { care- } \\
\text { seeking } \\
\text { behaviour } \\
\text { may exist } \\
\text { between } \\
\text { vaccin- } \\
\text { ated and } \\
\text { unvaccin- } \\
\text { ated } \\
\text { groups }\end{array}$ \\
\hline
\end{tabular}




\begin{tabular}{|c|c|c|c|c|c|c|}
\hline \multicolumn{5}{|c|}{ EVIDENCE RELATED TO TIV EFFICACY/EFFECTIVENESS } & \multirow[b]{2}{*}{$\begin{array}{l}\text { Level of } \\
\text { Evidence }\end{array}$} & \multirow[b]{2}{*}{ Quality } \\
\hline Study & Vaccine & Study Design & Participants & $\begin{array}{l}\text { Summary of Key Findings } \\
\text { Using Text or Data }\end{array}$ & & \\
\hline $\begin{array}{l}\text { Kelly H, Jacoby } \\
\text { P, Dixon GA, } \\
\text { et al. Vaccine } \\
\text { Effectiveness } \\
\text { Against } \\
\text { Laboratory- } \\
\text { confirmed } \\
\text { Influenza in } \\
\text { Healthy Young } \\
\text { Children: A } \\
\text { Case-Control } \\
\text { Study. Pediatr } \\
\text { Infect Dis J } \\
\text { 2011 Feb;30(2): } \\
\text { 107-111.(22) }\end{array}$ & 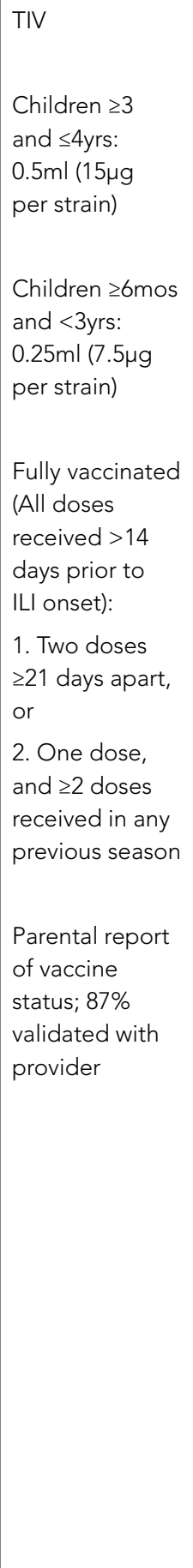 & $\begin{array}{l}\text { Prospective } \\
\text { incidence } \\
\text { density case } \\
\text { control } \\
2008 \text { season } \\
\text { Australia }\end{array}$ & $\begin{array}{l}\mathrm{N}=289 \\
\mathrm{n}_{\mathrm{ED}}=214 \\
\mathrm{n}_{\mathrm{GP}}=75 \\
\text { Children } \\
6-59 \mathrm{mos} \\
\text { (50.2\% of } \\
\text { participants } \\
>2 \mathrm{yrs}) \\
\\
\text { Recruitment } \\
\text { from hospital } \\
\text { ED and general } \\
\text { practices } \\
\\
6.9 \% \text { of } \\
\text { participants } \\
\text { with } \\
\text { comorbidity }\end{array}$ & 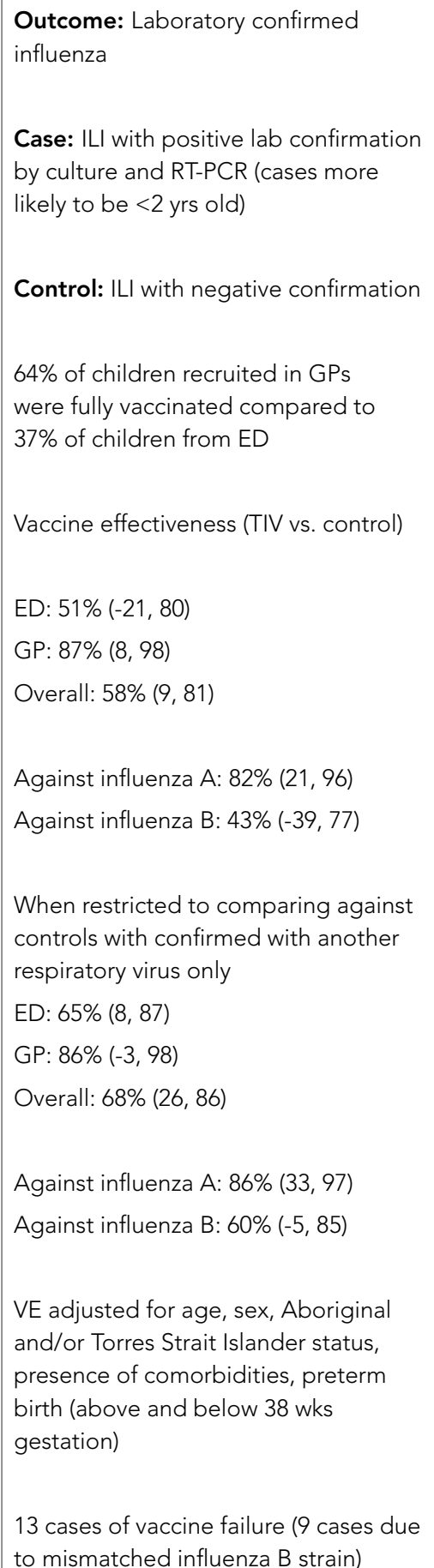 & Level II-2 & $\begin{array}{l}\text { Fair } \\
\text { More } \\
\text { than half } \\
\text { of } \\
\text { children } \\
\text { recruited } \\
\text { through } \\
\text { the GP } \\
\text { arm were } \\
\text { from a } \\
\text { practice } \\
\text { with a } \\
\text { vigorous } \\
\text { childhood } \\
\text { immun- } \\
\text { ization } \\
\text { program }\end{array}$ \\
\hline
\end{tabular}




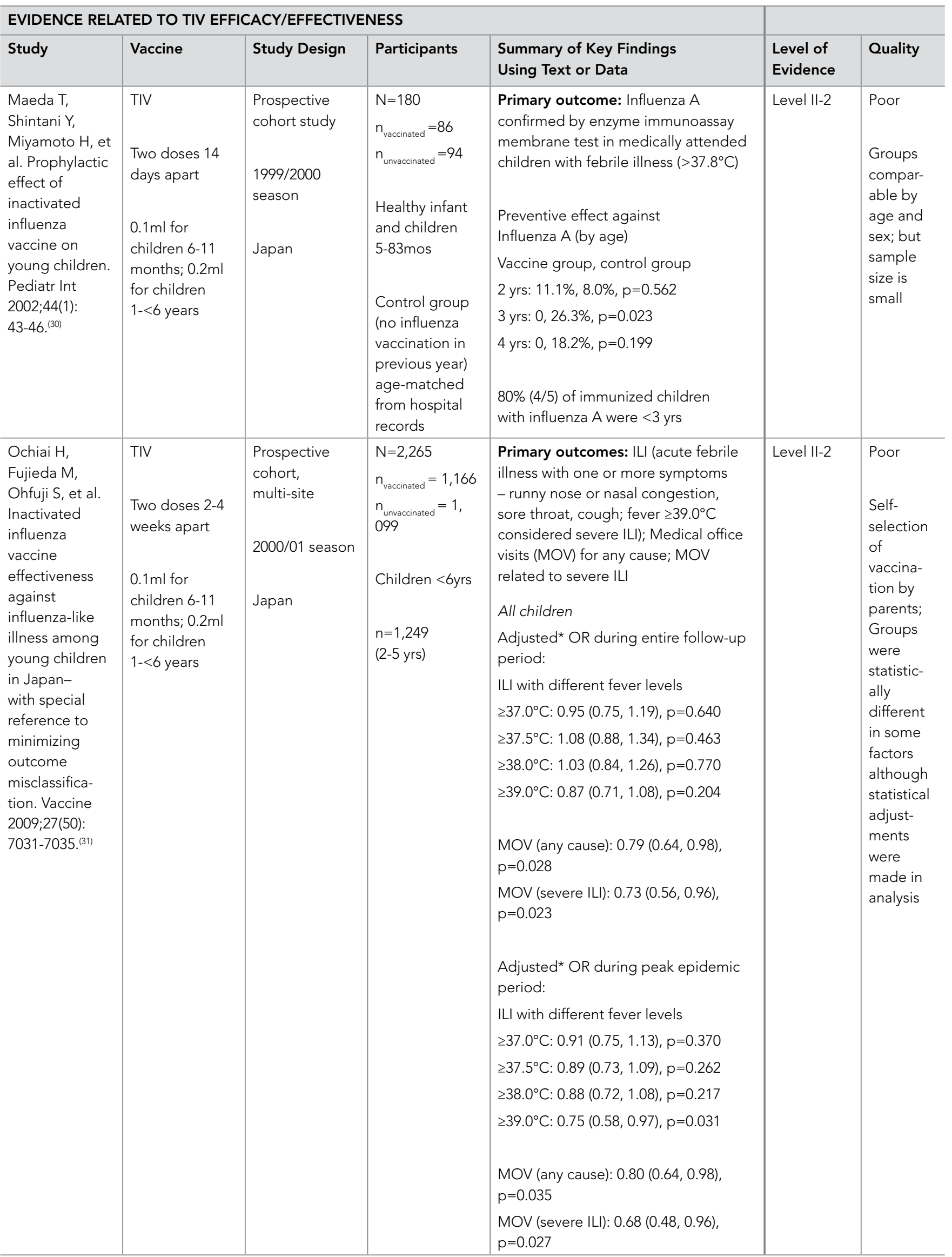




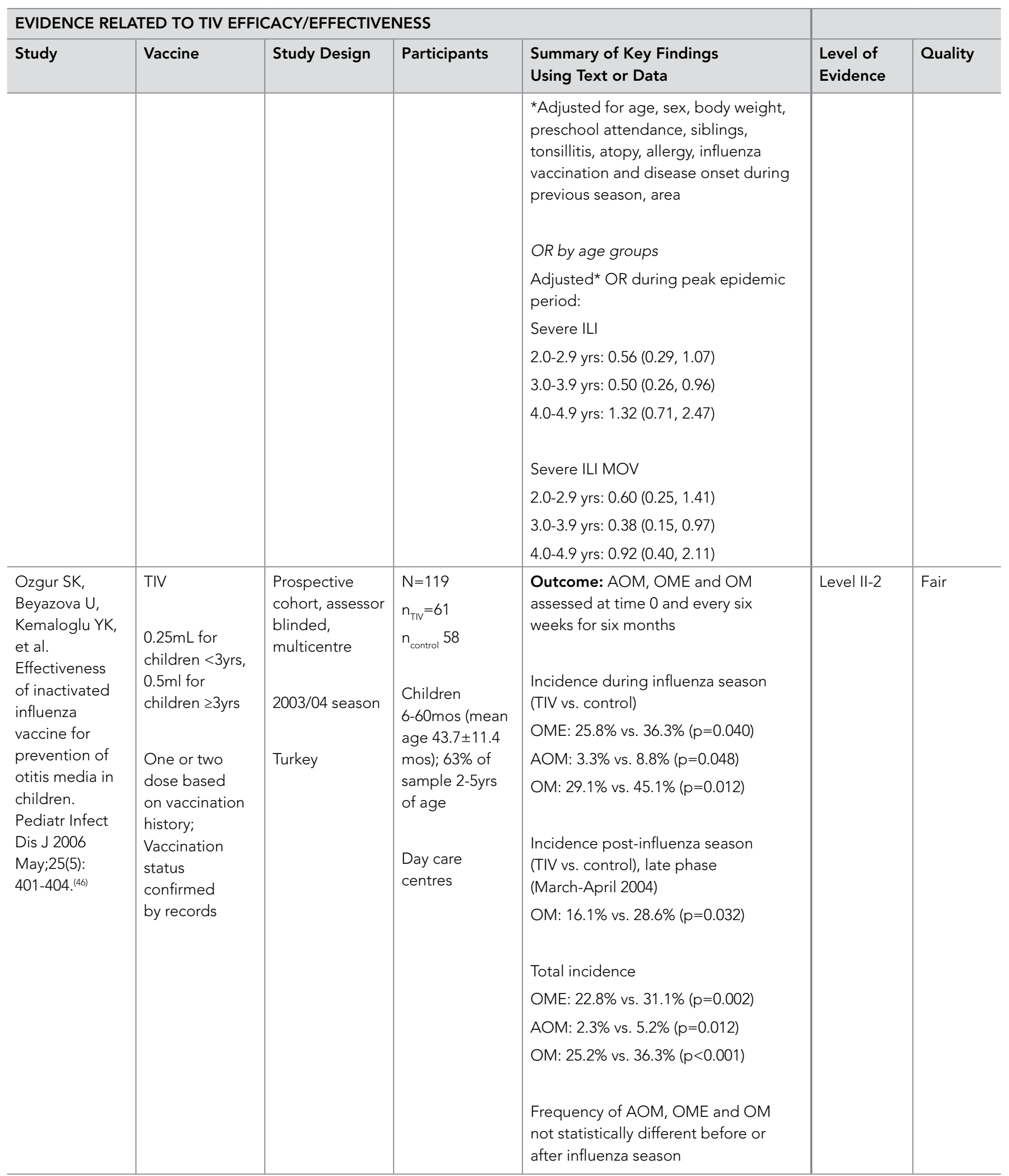




\begin{tabular}{|c|c|c|c|c|c|c|}
\hline \multicolumn{5}{|c|}{ EVIDENCE RELATED TO TIV EFFICACY/EFFECTIVENESS } & \multirow[b]{2}{*}{$\begin{array}{l}\text { Level of } \\
\text { Evidence }\end{array}$} & \multirow[b]{2}{*}{ Quality } \\
\hline Study & Vaccine & Study Design & Participants & $\begin{array}{l}\text { Summary of Key Findings } \\
\text { Using Text or Data }\end{array}$ & & \\
\hline $\begin{array}{l}\text { Ritzwoller DP, } \\
\text { Bridges CB, } \\
\text { Shetterly S, et } \\
\text { al. Effectiveness } \\
\text { of the 2003- } \\
2004 \text { influenza } \\
\text { vaccine among } \\
\text { children } 6 \\
\text { months to } 8 \\
\text { years of age, } \\
\text { with } 1 \text { vs } 2 \\
\text { doses. } \\
\text { Pediatrics } \\
2005 ; 116(1): \\
\text { 153-159.(19) }\end{array}$ & $\begin{array}{l}\text { TIV } \\
\text { Full vaccination } \\
\text { (All doses } \\
\text { received }>14 \\
\text { days prior to } \\
\text { ILI onset): } \\
\text { 1. Two doses, } \\
\text { or } \\
\text { 2. One dose, } \\
\text { and vaccinated } \\
\text { in previous } \\
\text { season } \\
\text { Partial } \\
\text { vaccination: } \\
\text { 1. one dose } \\
\text { received } \geq 14 \\
\text { days prior } \\
\text { to ILI onset }\end{array}$ & $\begin{array}{l}\text { Retrospective } \\
\text { cohort study } \\
\text { 2003/04 season } \\
\text { (peak weeks of } \\
\text { influenza } \\
\text { activity only: } \\
\text { Nov 19-Dec } 7 \text {, } \\
\text { 2003) }\end{array}$ & $\begin{array}{l}N=29,726 \\
n=5,139 \text { (6-23 } \\
\text { mos) } \\
n=24,587(2-8 \\
\text { yrs) } \\
\text { Children } \\
\text { 6mos-8 yrs }\end{array}$ & 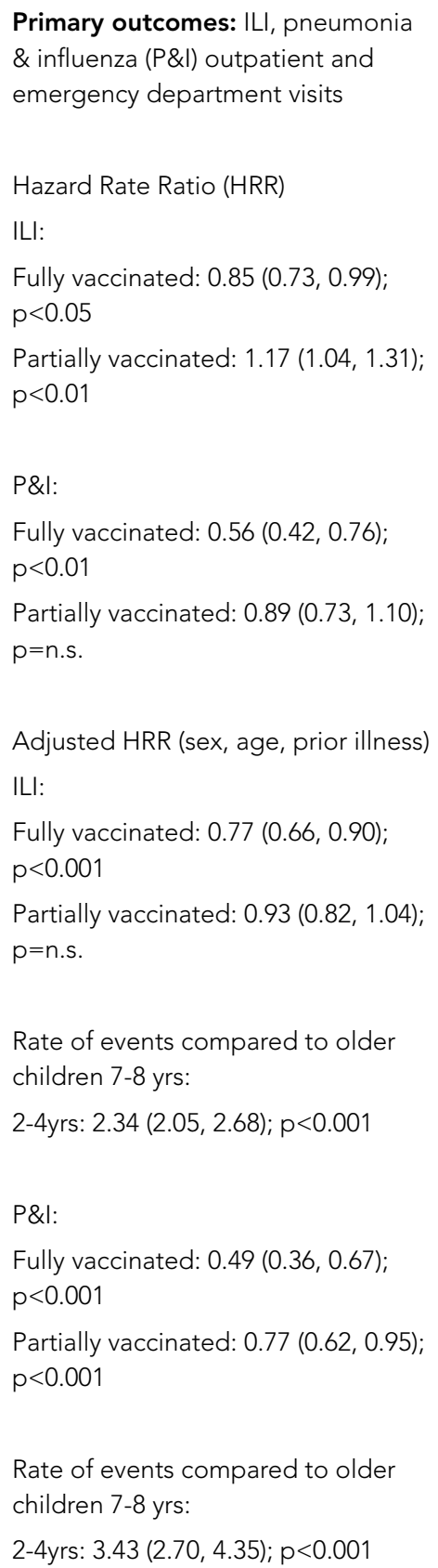 & Level II-2 & $\begin{array}{l}\text { Fair } \\
\text { Study } \\
\text { uses } \\
\text { adminis- } \\
\text { trative } \\
\text { data } \\
\text { without } \\
\text { labora- } \\
\text { tory } \\
\text { confirma- } \\
\text { tion of } \\
\text { outcomes } \\
\text { resulting } \\
\text { in } \\
\text { potential } \\
\text { for } \\
\text { misclassi- } \\
\text { fication }\end{array}$ \\
\hline
\end{tabular}




\begin{tabular}{|c|c|c|c|c|c|c|}
\hline \multicolumn{5}{|c|}{ EVIDENCE RELATED TO TIV EFFICACY/EFFECTIVENESS } & \multirow[b]{2}{*}{$\begin{array}{l}\text { Level of } \\
\text { Evidence }\end{array}$} & \multirow[b]{2}{*}{ Quality } \\
\hline Study & Vaccine & Study Design & Participants & $\begin{array}{l}\text { Summary of Key Findings } \\
\text { Using Text or Data }\end{array}$ & & \\
\hline $\begin{array}{l}\text { Shuler CM, } \\
\text { Iwamoto M, } \\
\text { Bridges CB, } \\
\text { et al. Vaccine } \\
\text { effectiveness } \\
\text { against } \\
\text { medically } \\
\text { attended, } \\
\text { laboratory- } \\
\text { confirmed } \\
\text { influenza } \\
\text { among children } \\
\text { aged 6 to } \\
59 \text { months, } \\
\text { 2003-2004. } \\
\text { Pediatrics } \\
\text { 2007;119(3): } \\
\text { e587-95.(24) }\end{array}$ & $\begin{array}{l}\text { TIV } \\
\text { Full vaccination } \\
\text { (all doses } \\
\text { received } \geq 14 \\
\text { days prior to } \\
\text { ILI onset): } \\
\text { 1. } 2 \text { doses } \geq 1 \\
\text { month apart, or } \\
\text { 2. } 1 \text { dose, and } \\
\text { vaccinated in } \\
\text { previous season } \\
\text { Partial } \\
\text { vaccination: } \\
\text { 1. } 2 \text { doses } \\
\text { received with } \\
\text { ILI onset }<14 \\
\text { days after last } \\
\text { dose, or } \\
2.1 \text { dose, not } \\
\text { vaccinated in } \\
\text { previous } \\
\text { season, and } \\
\geq 14 \text { days before } \\
\text { ILI onset } \\
\text { Suboptimal } \\
\text { antigenic } \\
\text { matching } \\
\text { between } \\
\text { vaccine and } \\
\text { circulating } \\
\text { strains }\end{array}$ & $\begin{array}{l}\text { Case control } \\
\text { 2003/04 season } \\
\text { US }\end{array}$ & $\begin{array}{l}\mathrm{N}=870 \\
\mathrm{n}_{\text {case }}=290 \\
\mathrm{n}_{\text {control }}=580 \\
\text { Children } \\
\text { 6-59mos from } \\
\text { study clinic } \\
\text { (19.0-22.1\% of } \\
\text { participants } \\
\text { with high risk } \\
\text { conditions e.g. } \\
\text { renal disease, } \\
\text { immunosup- } \\
\text { pression, } \\
\text { metabolic } \\
\text { disease) }\end{array}$ & $\begin{array}{l}\text { Case: Medically attended with } \\
\text { laboratory-confirmed influenza } \\
\text { (confirmed by QuickVue Influenza test) } \\
\text { Control: Age-matched, born the same } \\
\text { month as case (two controls per case) } \\
\text { Adjusted OR (6-59mos) } \\
\text { Fully vaccinated vs. unvaccinated: } 0.51 \\
(0.4,0.7) ; p<0.01 \text { (VE = 49\%) } \\
\text { Partially vaccinated vs. unvaccinated: } \\
0.76 \text { (0.5, } 1.2) ; p=n . s \text {. } \\
\text { Adjusted OR ( } 24-59 \text { mos) } \\
\text { Fully vaccinated vs. unvaccinated: } 0.55 \\
(0.3,0.9) ; p<0.05 \text { (VE = 45\%) } \\
\text { Partially vaccinated vs. unvaccinated: } \\
0.35 \text { (0.2, } 0.7) ; p<0.05 \text { (VE = 65\%) } \\
\text { Adjusted for high-risk status and } \\
\text { health care usage according to age } \\
\text { category }\end{array}$ & Level II-2 & $\begin{array}{l}\text { Fair } \\
\text { Evalua- } \\
\text { tors not } \\
\text { blinded } \\
\text { to } \\
\text { vaccina- } \\
\text { tion } \\
\text { status } \\
\text { introdu- } \\
\text { cing } \\
\text { potential } \\
\text { for } \\
\text { diagnos- } \\
\text { tic testing } \\
\text { bias } \\
\text { (misclassi- } \\
\text { fication of } \\
\text { cases as } \\
\text { controls) }\end{array}$ \\
\hline
\end{tabular}




\begin{tabular}{|c|c|c|c|c|c|c|}
\hline \multicolumn{5}{|c|}{ EVIDENCE RELATED TO TIV EFFICACY/EFFECTIVENESS } & \multirow[b]{2}{*}{$\begin{array}{l}\text { Level of } \\
\text { Evidence }\end{array}$} & \multirow[b]{2}{*}{ Quality } \\
\hline Study & Vaccine & Study Design & Participants & $\begin{array}{l}\text { Summary of Key Findings } \\
\text { Using Text or Data }\end{array}$ & & \\
\hline $\begin{array}{l}\text { Staat MA, } \\
\text { Griffin MR, } \\
\text { Donauer S, } \\
\text { et al. Vaccine } \\
\text { effectiveness } \\
\text { for laboratory- } \\
\text { confirmed } \\
\text { influenza in } \\
\text { children 6-59 } \\
\text { months of age, } \\
\text { 2005-2007. } \\
\text { Vaccine } \\
2011 ; 29(48) \text { : } \\
9005-9011 .{ }^{(23)}\end{array}$ & $\begin{array}{l}\text { TIV } \\
\text { Full vaccination } \\
\text { (All doses } \\
\text { received } \geq 14 \\
\text { days prior to } \\
\text { ILI onset): } \\
\text { 1. Two doses } \\
\geq 24 \text { days apart, } \\
\text { or } \\
\text { 2. One dose, } \\
\text { and } \geq 1 \text { dose } \\
\text { received in a } \\
\text { previous season } \\
\text { Partial } \\
\text { vaccination: } \\
\text { 1. Only } 1 \text { of } 2 \\
\text { doses received } \\
\geq 14 \text { days to ILI } \\
\text { onset, or } 2 \text {. } 2 \\
\text { doses received } \\
\text { with second } \\
\text { dose }<24 \text { days } \\
\text { after first dose }\end{array}$ & $\begin{array}{l}\text { Case control, } \\
\text { multi-site } \\
2005 / 06 \text { \& } \\
2006 / 07 \\
\text { seasons } \\
\text { US }\end{array}$ & $\begin{array}{l}2005 / 06 \\
N=268 \\
n_{\text {case }}=85 \\
n_{\text {control }}=183 \\
2006 / 07 \\
N=528 \\
n_{\text {case }}=158 \\
n_{\text {control }}=370 \\
\text { Children } \\
\text { 6-59mos } \\
\text { Inpatient and } \\
\text { outpatient } \\
\text { enrolment }\end{array}$ & 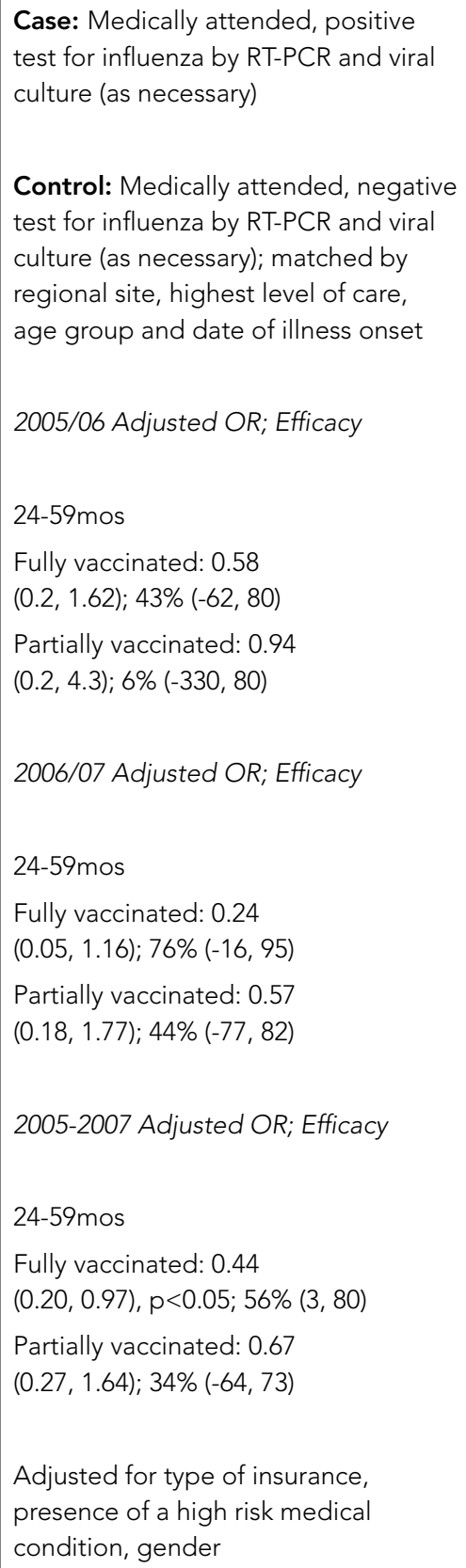 & Level II-2 & Good \\
\hline
\end{tabular}




\begin{tabular}{|c|c|c|c|c|c|c|}
\hline \multicolumn{5}{|c|}{ EVIDENCE RELATED TO TIV EFFICACY/EFFECTIVENESS } & \multirow[b]{2}{*}{$\begin{array}{l}\text { Level of } \\
\text { Evidence }\end{array}$} & \multirow[b]{2}{*}{ Quality } \\
\hline Study & Vaccine & Study Design & Participants & $\begin{array}{l}\text { Summary of Key Findings } \\
\text { Using Text or Data }\end{array}$ & & \\
\hline $\begin{array}{l}\text { Szilagyi PG, } \\
\text { Fairbrother G, } \\
\text { Griffin MR, } \\
\text { et al. Influenza } \\
\text { vaccine } \\
\text { effectiveness } \\
\text { among children } \\
6 \text { to } 59 \text { months } \\
\text { of age during } \\
2 \text { influenza } \\
\text { seasons: a } \\
\text { case-cohort } \\
\text { study. Arch } \\
\text { Pediatr } \\
\text { Adolesc Med } \\
2008 ; 162(10): \\
943-951 .(28)\end{array}$ & $\begin{array}{l}\text { TIV } \\
\text { Full vaccination } \\
\text { (All doses } \\
\text { received >14 } \\
\text { days prior to ILI } \\
\text { onset): } \\
\text { 1. } 2 \text { doses }>24 \\
\text { days apart, or } \\
\text { 2. } 1 \text { dose, and } \\
>1 \text { dose } \\
\text { received in a } \\
\text { previous season } \\
\text { Partial } \\
\text { vaccination: } \\
\text { 1. Only } 1 \text { of } 2 \\
\text { doses received } \\
\geq 14 \text { days to ILI } \\
\text { onset, or } 2.2 \\
\text { doses received } \\
\text { with second } \\
\text { dose <24 days } \\
\text { after first dose } \\
\text { Suboptimal } \\
\text { antigenic } \\
\text { matching } \\
\text { between } \\
\text { vaccine and } \\
\text { circulating } \\
\text { strains in both } \\
\text { study seasons }\end{array}$ & $\begin{array}{l}\text { Case cohort, } \\
\text { multi-site } \\
\text { 2003/04 \& } \\
\text { 2004/05 } \\
\text { seasons }\end{array}$ & $\begin{array}{l}\text { Inpatient/ED } \\
N=9,468 \\
n_{\text {case }}=245 \\
n_{\text {control }}=9223 \\
\text { Outpatient } \\
\text { practice } \\
\mathrm{N}=1,438 \\
\mathrm{n}_{\text {case }}=169 \\
\mathrm{n}_{\text {control }}=1269 \\
\text { Children } \\
\text { 6-59mos } \\
\text { Enrolment from } \\
\text { inpatient/ } \\
\text { emergency } \\
\text { department } \\
\text { (ED) and } \\
\text { outpatient (for } \\
2 \text { consecutive } \\
\text { seasons) } \\
\text { population } \\
\text { Cases found } \\
\text { prospectively } \\
\text { by ARI visit, } \\
\text { controls found } \\
\text { retrospectively } \\
\text { from medical } \\
\text { records }\end{array}$ & 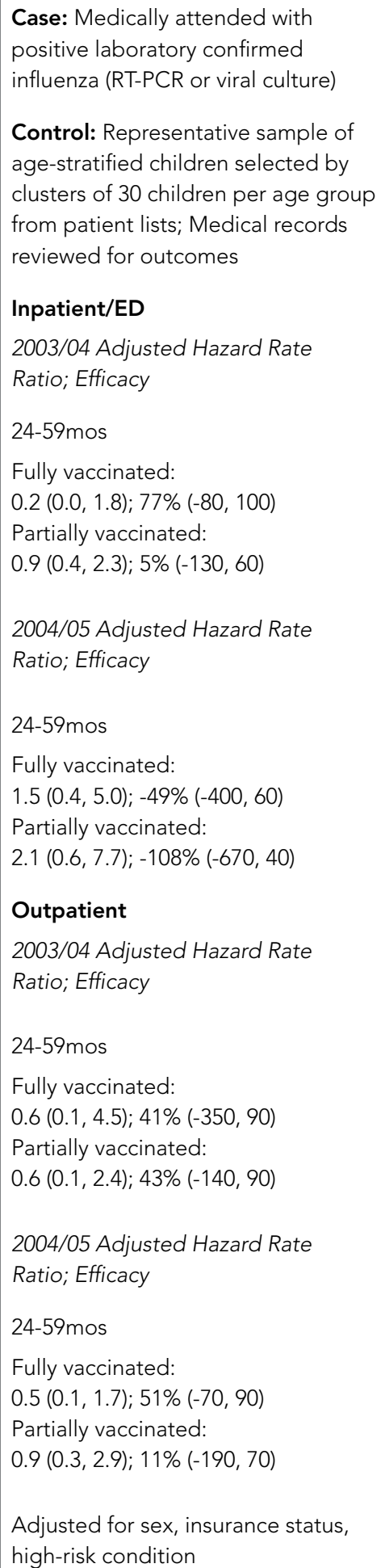 & Level II-2 & $\begin{array}{l}\text { Fair } \\
\text { Study } \\
\text { design } \\
\text { may be } \\
\text { insuffi- } \\
\text { cient in } \\
\text { determin- } \\
\text { ing } \\
\text { factors } \\
\text { such as } \\
\text { propen- } \\
\text { sity to } \\
\text { seek care } \\
\text { which } \\
\text { affects } \\
\text { estimates }\end{array}$ \\
\hline
\end{tabular}


TABLE 5B: Evidence tables for children 24 to 59 months of age - Evidence related to Indirect Effects

\begin{tabular}{|c|c|c|c|c|c|c|}
\hline \multicolumn{5}{|c|}{ EVIDENCE RELATED TO INDIRECT EFFECTS } & \multirow[b]{2}{*}{$\begin{array}{l}\text { Level of } \\
\text { Evidence }\end{array}$} & \multirow[b]{2}{*}{ Quality } \\
\hline Study & Vaccine & Study Design & Participants & $\begin{array}{l}\text { Summary of Key Findings } \\
\text { Using Text or Data }\end{array}$ & & \\
\hline $\begin{array}{l}\text { Hurwitz ES, } \\
\text { Haber M, } \\
\text { Chang A, et al. } \\
\text { Effectiveness } \\
\text { of influenza } \\
\text { vaccination } \\
\text { of day care } \\
\text { children in } \\
\text { reducing } \\
\text { influenza- } \\
\text { related } \\
\text { morbidity } \\
\text { among } \\
\text { household } \\
\text { contacts. } \\
\text { JAMA 2000; } \\
284(13) \text { : } \\
\text { 1677-1682. }{ }^{(47)}\end{array}$ & $\begin{array}{l}\text { TIV } \\
\text { Hepatitis A as } \\
\text { control vaccine } \\
\text { For both } \\
\text { vaccines: } 2 \\
\text { doses given } 1 \\
\text { month apart } \\
\text { at standard } \\
\text { recommended } \\
\text { dosages }\end{array}$ & $\begin{array}{l}\text { RCT, single } \\
\text { blind (parents) } \\
\text { 1996/97 season } \\
\text { US }\end{array}$ & $\begin{array}{l}\mathrm{N}=127 \\
\mathrm{n}_{\mathrm{TIV}}=60 \\
\mathrm{n}_{\text {HepA }}=67 \\
24-60 \mathrm{~m} / \mathrm{O} \\
\text { Influenza } \\
\text { vaccine naïve } \\
\text { US Navy- } \\
\text { affiliated day } \\
\text { care centres }\end{array}$ & $\begin{array}{l}\text { VE not statistically significant } \\
\text { in vaccinated children } \\
\text { VE for unvaccinated household } \\
\text { contacts } \\
\text { Respiratory illness with fever: } \\
42 \% \text { ( } p=0.04 \text { ) } \\
\text { Respiratory illness with temperature } \\
\geq 38^{\circ} \mathrm{C} \text { : } 48 \% \text { ( } p=0.04 \text { ) } \\
\text { VE for vaccinated household contacts } \\
\text { Any: } 28 \% \text { ( } p=0.04 \text { ) } \\
\text { VE for unvaccinated } 5-17 y / 0 \text { household } \\
\text { contacts ranges from } 45-100 \% \text { for } \\
\text { missed school, adult missed work, } \\
\text { physician visits, ear ache, antibiotics } \\
\text { prescribed, and OTC medications } \\
\text { used (all statistically significant) - not } \\
\text { observed for adults or children }<5 y / 0\end{array}$ & Level I & $\begin{array}{l}\text { Good } \\
\text { Small } \\
\text { numbers } \\
\text { for some } \\
\text { sub- } \\
\text { analyses }\end{array}$ \\
\hline $\begin{array}{l}\text { Loeb M, Russell } \\
\text { ML, Moss L, } \\
\text { et al. Effect } \\
\text { of influenza } \\
\text { vaccination } \\
\text { of children on } \\
\text { infection rates } \\
\text { in Hutterite } \\
\text { communities. } \\
\text { JAMA 2010; } \\
\text { 303(10): } \\
\text { 943-950. }{ }^{(50)}\end{array}$ & $\begin{array}{l}\text { Hepatitis A as } \\
\text { control vaccine }\end{array}$ & $\begin{array}{l}\text { Cluster RCT (49 } \\
\text { communities) } \\
\text { 2008/09 season } \\
\text { Canada }\end{array}$ & $\begin{array}{l}\mathrm{N}=3,273 \\
\mathrm{n}_{\text {unvaccinated }}= \\
2,326 \\
\mathrm{n}_{\text {vaccinated }}=947 \\
\text { Only children } \\
36 \mathrm{~m}-15 \mathrm{y} \\
\text { received } \\
\text { vaccine } \\
\mathrm{n}_{\text {TIV }}=502 \\
\mathrm{n}_{\text {HepA }}=445\end{array}$ & $\begin{array}{l}\text { Outcome: Lab-confirmed influenza } \\
\text { (RT-PCR) } \\
\text { Indirect vaccine protectiveness } \\
\text { (non-recipients): } 61 \%(8,83 \%, p=0.03) \\
\text { Hazard ratio for anti-microbial } \\
\text { prescriptions: } 0.58(0.34,0.99, p=0.046) \\
\text { No statistically significant hazard ratios } \\
\text { for physician visits for respiratory visits, } \\
\text { influenza-like illness and OM }\end{array}$ & Level I & Good \\
\hline
\end{tabular}




\begin{tabular}{|c|c|c|c|c|c|c|}
\hline \multicolumn{5}{|c|}{ EVIDENCE RELATED TO INDIRECT EFFECTS } & \multirow[b]{2}{*}{$\begin{array}{l}\text { Level of } \\
\text { Evidence }\end{array}$} & \multirow[b]{2}{*}{ Quality } \\
\hline Study & Vaccine & Study Design & Participants & $\begin{array}{l}\text { Summary of Key Findings } \\
\text { Using Text or Data }\end{array}$ & & \\
\hline $\begin{array}{l}\text { Piedra PA, } \\
\text { Gaglani MJ, } \\
\text { Kozinetz CA, } \\
\text { et al. Herd } \\
\text { immunity in } \\
\text { adults against } \\
\text { influenza- } \\
\text { related illnesses } \\
\text { with use of the } \\
\text { trivalent-live } \\
\text { attenuated } \\
\text { influenza } \\
\text { vaccine (CAIV-T) } \\
\text { in children. } \\
\text { Vaccine } \\
\text { 2005;23(13): } \\
\text { 1540-8.(49) }\end{array}$ & LAIV & 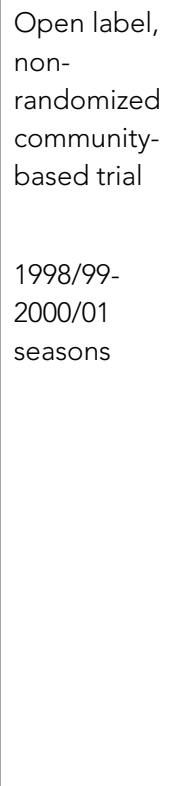 & $\begin{array}{l}\text { Cumulative } \\
\text { children } \\
\text { vaccinated in } \\
\text { community } \\
\mathrm{N}=9,765 \\
\text { Cumulative } \\
\text { children } \\
\text { vaccinated for } \\
\text { members of the } \\
\text { Scott White } \\
\text { Health Plan } \\
\mathrm{N}=4,774 \\
\text { 18m-18y } \\
\text { eligible for } \\
\text { vaccine }\end{array}$ & $\begin{array}{l}\text { Outcome: MAARI } \\
\text { 20-25\% of eligible children received } \\
\text { LAIV each year } \\
\text { Comparing rates of MAARI in all } \\
\text { members of the Scott and White } \\
\text { Health Plan, risk of MAARI was } \\
\text { decreased in adults } \geq 35 y / 0 \text { during all } \\
\text { three vaccination years when } \\
\text { comparing intervention to control } \\
\text { communities } \\
\text { RR for MAARI in adults } \geq 35 y / 0 \text { ranged } \\
\text { from } 0.08-0.18 \\
\text { Estimated medical visits avoided in } \\
\text { adults } \geq 35 y / 0: 303-781\end{array}$ & Level II-3 & Fair \\
\hline
\end{tabular}


TABLE 5C: Evidence tables for children 24 to 59 months of age - Evidence related to Safety

\begin{tabular}{|c|c|c|c|c|c|c|}
\hline \multicolumn{5}{|c|}{ EVIDENCE FOR SAFETY } & \multirow[b]{2}{*}{$\begin{array}{l}\text { Level of } \\
\text { Evidence }\end{array}$} & \multirow[b]{2}{*}{ Quality } \\
\hline Study & Vaccine & Study Design & Participants & $\begin{array}{l}\text { Summary of Key Findings } \\
\text { Using Text or Data }\end{array}$ & & \\
\hline $\begin{array}{l}\text { Baxter R, } \\
\text { Jeanfreau R, } \\
\text { Block SL, et al. } \\
\text { A Phase III } \\
\text { evaluation of } \\
\text { immunogen- } \\
\text { icity and safety } \\
\text { of two trivalent } \\
\text { inactivated } \\
\text { seasonal } \\
\text { influenza } \\
\text { vaccines in } \\
\text { US children. } \\
\text { Pediatr Infect } \\
\text { Dis J 2010 } \\
\text { Oct;29(10):924- } \\
\text { 930.(57) }\end{array}$ & $\begin{array}{l}\text { TIV } \\
\text { Experimental } \\
\text { Fluarix }^{\circledR} \\
\text { Active } \\
\text { comparator } \\
\text { Fluzone }{ }^{\circledR} \\
\text { Dose } \\
\text { - } 6 \text { months } \\
\text { to <3years } \\
0.25 \text { ml } \\
\text { - } 3 \text { years to }<5 \\
\text { years } 0.5 \mathrm{ml} \\
\text { Schedule } \\
\text { - second dose } \\
\text { day } 28 \text { in } \\
\text { vaccine } \\
\text { naïve } \\
\text { participants } \\
<9 \text { years } \\
\text { Formulation } \\
\text { - both } \\
\text { vaccines, } \\
15 \mu g \text { HA } \\
\text { Northern } \\
\text { Hemisphere } \\
\text { strains } 06-07\end{array}$ & $\begin{array}{l}\text { PIIl single blind, } \\
\text { multicentre } \\
\text { randomized } \\
\text { trial } \\
2006-07 \\
\text { influenza } \\
\text { season } \\
\text { US (42 sites) }\end{array}$ & $\begin{array}{l}\text { Children } \\
6 \text { months } \\
\text { to } 18 \text { years } \\
\text { (excluding } \\
\text { those with } \\
\text { acute disease) } \\
\mathrm{N}=3,325 \text { ( } 2,115 \\
\text { experimental } \\
\text { and } 1,210 \\
\text { active control) } \\
\text { Subset } \\
\text { vaccinated } \\
\text { participants } \\
6 \text { months } \\
\text { to } 5 \text { years } \\
\text { N=2,992 } \\
\text { (experimental } \\
\text { arm } 375 \text { ( } 18 \% \text { ) } \\
\text { from } 6 \text { to } 36 \\
\text { months and } 373 \\
\text { (12\%) from } 3 \text { to } \\
5 \text { years; control } \\
\text { arm } 379 \text { ( } 31 \% \text { ) } \\
\text { from } 6 \text { to } 36 \\
\text { months and } \\
369 \text { (30\%) from } \\
3 \text { to } 5 \text { years) }\end{array}$ & 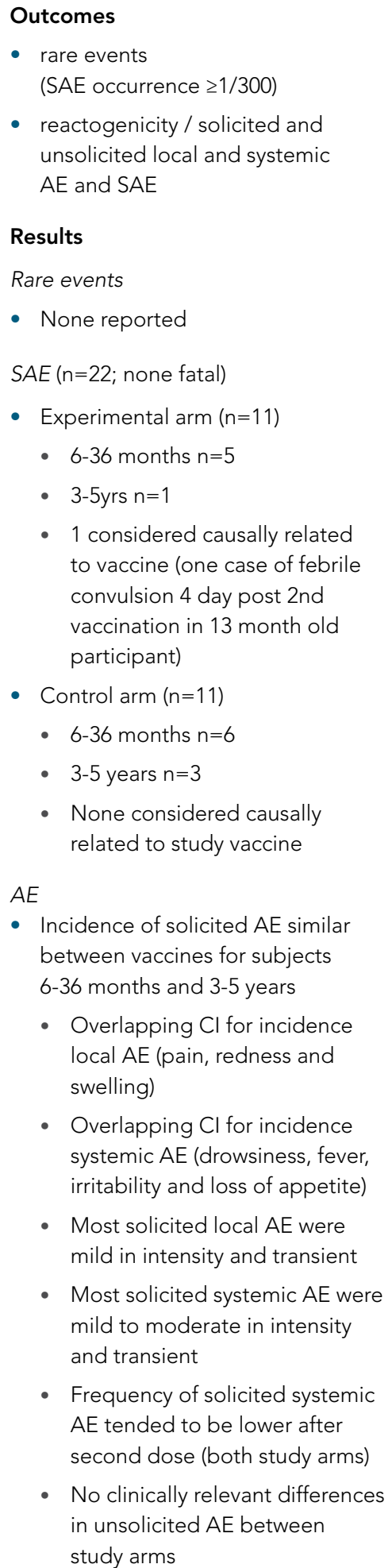 & Level I & Good \\
\hline
\end{tabular}




\begin{tabular}{|c|c|c|c|c|c|c|}
\hline \multicolumn{5}{|c|}{ EVIDENCE FOR SAFETY } & \multirow[b]{2}{*}{$\begin{array}{l}\text { Level of } \\
\text { Evidence }\end{array}$} & \multirow[b]{2}{*}{ Quality } \\
\hline Study & Vaccine & Study Design & Participants & $\begin{array}{l}\text { Summary of Key Findings } \\
\text { Using Text or Data }\end{array}$ & & \\
\hline $\begin{array}{l}\text { Glanz JM, } \\
\text { Newcomer SR, } \\
\text { Hambidge SJ, } \\
\text { et al. Safety } \\
\text { of trivalent } \\
\text { inactivated } \\
\text { influenza } \\
\text { vaccine in } \\
\text { children aged } \\
24 \text { to } 59 \text { months } \\
\text { in the vaccine } \\
\text { safety datalink. } \\
\text { Arch Pediatr } \\
\text { Adolesc } \\
\text { Med 2011 } \\
\text { Aug;165(8): } \\
\text { 749-755.(59) }\end{array}$ & TIV & $\begin{array}{l}\text { Self-controlled } \\
\text { screening study } \\
\text { (multicentre) } \\
\text { 2002-06 } \\
\text { influenza } \\
\text { seasons } \\
\text { US }\end{array}$ & $\begin{array}{l}\text { Children } 24-59 \\
\text { months with } \\
\geq 1 \text { dose of } \\
\text { TIV over study } \\
\text { period } \\
\mathrm{N}=66,283 \\
\text { (children) } \\
\text { (High-risk } \\
\text { conditions } \\
n=2,584 \text { (3.9\%)) } \\
\mathrm{N}=91,692 \\
\text { (doses) }\end{array}$ & 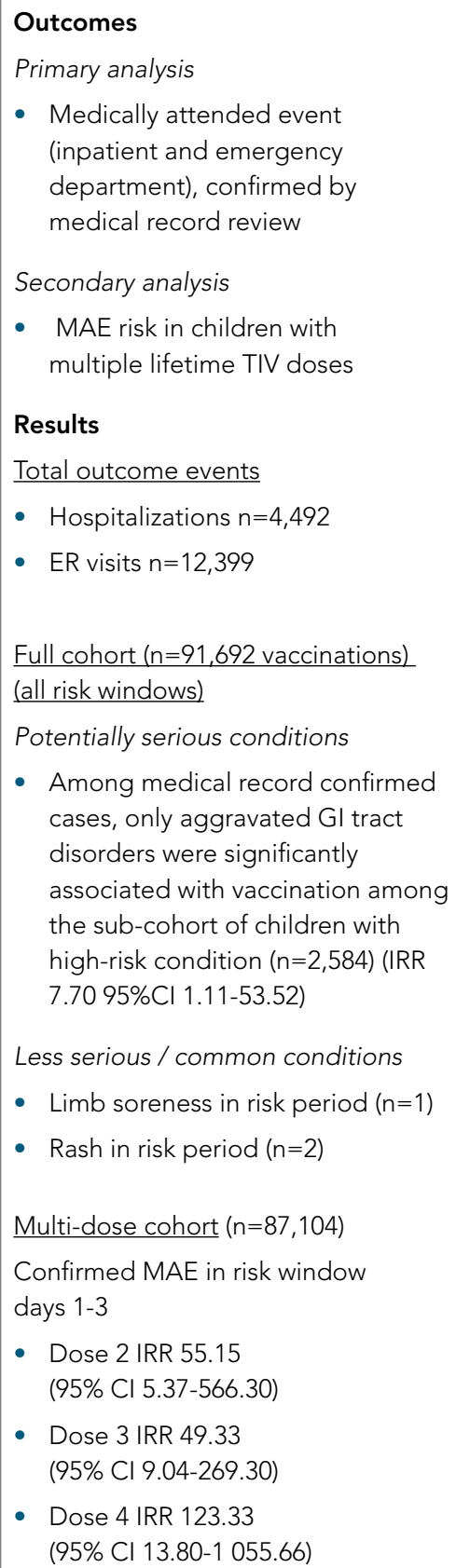 & Level II-2 & Fair \\
\hline
\end{tabular}




\begin{tabular}{|c|c|c|c|c|c|c|}
\hline \multicolumn{5}{|c|}{ EVIDENCE FOR SAFETY } & \multirow[b]{2}{*}{$\begin{array}{l}\text { Level of } \\
\text { Evidence }\end{array}$} & \multirow[b]{2}{*}{ Quality } \\
\hline Study & Vaccine & Study Design & Participants & $\begin{array}{l}\text { Summary of Key Findings } \\
\text { Using Text or Data }\end{array}$ & & \\
\hline $\begin{array}{l}\text { Jansen AG, } \\
\text { Sanders EA, } \\
\text { Smulders S, } \\
\text { et al. Adverse } \\
\text { reactions to } \\
\text { simultaneous } \\
\text { influenza and } \\
\text { pneumococcal } \\
\text { conjugate } \\
\text { vaccinations } \\
\text { in children: } \\
\text { randomized } \\
\text { double-blind } \\
\text { controlled trial. } \\
\text { Pediatr Allergy } \\
\text { Immunol 2008 } \\
\text { Sep;19(6): } \\
\text { 552-558. }{ }^{(58)}\end{array}$ & $\begin{array}{l}\text { TIV } \\
\text { Experimental } \\
\text { arm } \\
\text { - TIV + } \\
\text { heptavalent } \\
\text { pneumococ- } \\
\text { cal vaccine } \\
\text { (PCV7) } \\
\text { Control arm } 1 \\
\text { - TIV+ } \\
\text { placebo } \\
\text { Control arm } 2 \\
\text { - HBV vaccine } \\
+ \text { placebo } \\
\text { Schedule } \\
\text { - } 2 \text { sets of } \\
\text { vaccinations } \\
4-8 \text { wks } \\
\text { apart }\end{array}$ & 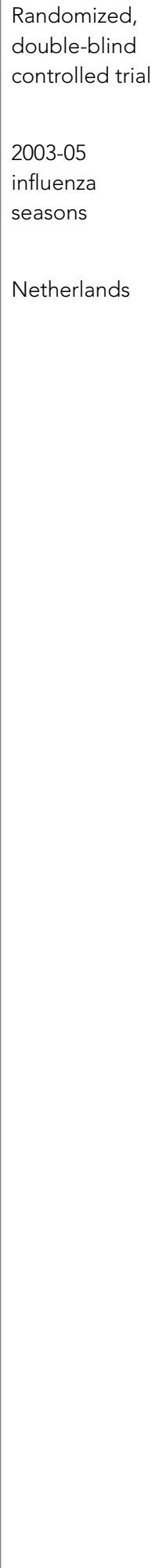 & $\begin{array}{l}\text { Children 18-72 } \\
\text { months with } \\
\text { previous } \\
\text { respiratory tract } \\
\text { infections } \\
\mathrm{N}=567 \\
\mathrm{n}_{\mathrm{TV}+\mathrm{PCV} 7}=194 \\
\mathrm{n}_{\mathrm{HBV}+\text { placebo }}=190 \\
\mathrm{n}_{\mathrm{TIV}+\text { placebo }}=183\end{array}$ & 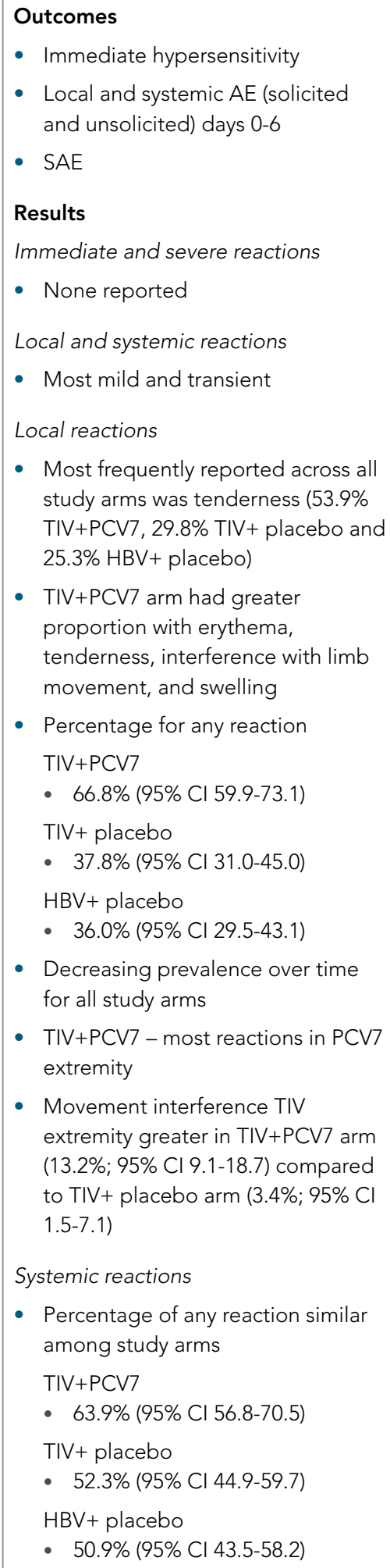 & Level I & Good \\
\hline
\end{tabular}




\begin{tabular}{|c|c|c|c|c|c|c|}
\hline \multicolumn{5}{|c|}{ EVIDENCE FOR SAFETY } & \multirow[b]{2}{*}{$\begin{array}{l}\text { Level of } \\
\text { Evidence }\end{array}$} & \multirow[b]{2}{*}{ Quality } \\
\hline Study & Vaccine & Study Design & Participants & $\begin{array}{l}\text { Summary of Key Findings } \\
\text { Using Text or Data }\end{array}$ & & \\
\hline & & & & $\begin{array}{l}\text { Clinic visit during follow-up - } \\
\text { not related to previous visit }(n=4) \\
\text { - TIV+ placebo } n=3 \text { (one } \\
\text { excessive crying and vomiting; } \\
2 \text { with coughing and shortness } \\
\text { of breath) } \\
\text { - HBV+ placebo } n=1 \text { (rash) }\end{array}$ & & \\
\hline $\begin{array}{l}\text { Ashkenazi S, } \\
\text { Vertruyen A, } \\
\text { Aristegui J, } \\
\text { et al. Superior } \\
\text { relative } \\
\text { efficacy of live } \\
\text { attenuated } \\
\text { influenza } \\
\text { vaccine } \\
\text { compared } \\
\text { with inactivated } \\
\text { influenza } \\
\text { vaccine in } \\
\text { young children } \\
\text { with recurrent } \\
\text { respiratory } \\
\text { tract infections. } \\
\text { Pediatr Infect } \\
\text { Dis J. 2006; } \\
25(10): 870-9 .(37)\end{array}$ & $\begin{array}{l}\text { TIV/LAIV } \\
\text { Study vaccine } \\
\text { LAIV } \\
\text { Dose - } 0.1 \mathrm{~mL} \\
\text { per nostril } \\
\text { Comparison } \\
\text { vaccine } \\
\text { TIV - types A } \\
\text { and B, split } \\
\text { virion } \\
\text { Dose } \\
\text { 6- } 36 \text { months } \\
0.25 \text { mL } \\
\text { per dose } \\
\text { - } 36-72 \\
\text { months } 0.5 \\
\text { mL } \\
\text { per dose } \\
\text { Vaccine } \\
\text { schedule } \\
2 \text { doses: } \\
35 \mathrm{~d} \pm 7 \mathrm{~d} \text { apart }\end{array}$ & $\begin{array}{l}\text { PIII RCT, } \\
\text { open-label, } \\
\text { active } \\
\text { controlled, } \\
\text { multicentre } \\
2002-2003 \\
\text { Influenza } \\
\text { season } \\
\text { Study sites } \\
\text { Europe, Israel }\end{array}$ & $\begin{array}{l}\mathrm{N}=2,187 \\
\mathrm{n}_{\text {TIV }}=1,086 \\
\mathrm{n}_{\text {LAIV }}=1,101 \\
\text { Children } 6 \\
\text { to } 71 \text { months, } \\
\text { with history } \\
\text { of recurrent } \\
\text { respiratory } \\
\text { tract infections } \\
\text { ( } \geq 2 \text { RTls in past } \\
12 \text { months or } \\
\text { since birth if } \\
\text { under 12 } \\
\text { months) } \\
\text { 23\% had prior } \\
\text { diagnosis of } \\
\text { asthma }\end{array}$ & 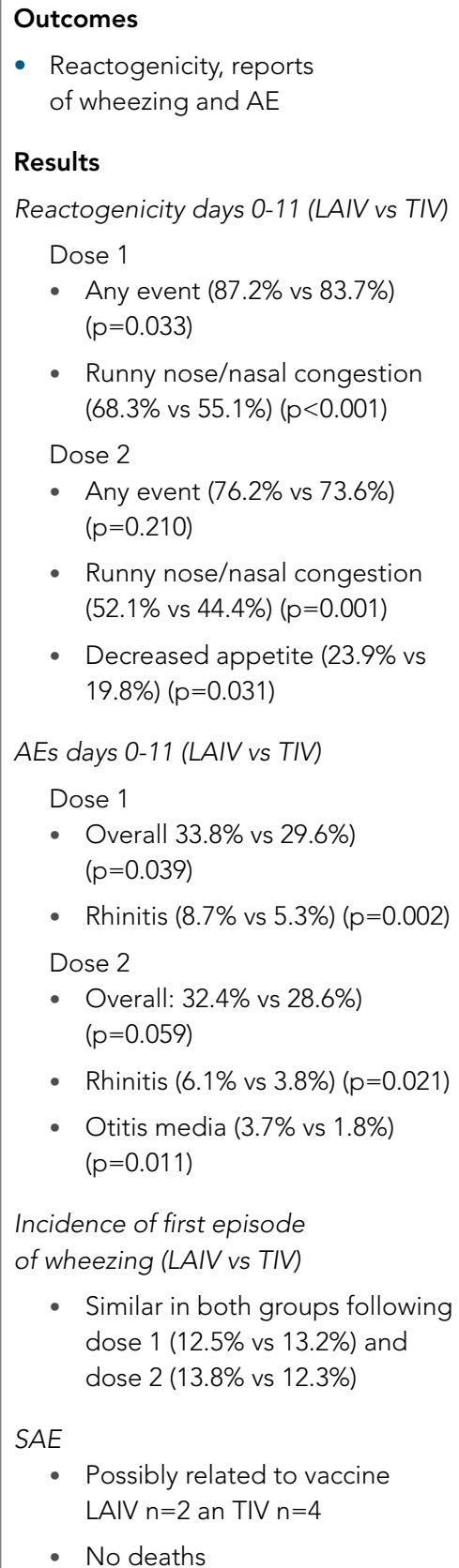 & Level I & Good \\
\hline
\end{tabular}




\begin{tabular}{|c|c|c|c|c|c|c|}
\hline \multicolumn{5}{|c|}{ EVIDENCE FOR SAFETY } & \multirow[b]{2}{*}{$\begin{array}{l}\text { Level of } \\
\text { Evidence }\end{array}$} & \multirow[b]{2}{*}{ Quality } \\
\hline Study & Vaccine & Study Design & Participants & $\begin{array}{l}\text { Summary of Key Findings } \\
\text { Using Text or Data }\end{array}$ & & \\
\hline $\begin{array}{l}\text { Belshe RB, } \\
\text { Edwards KM, } \\
\text { Vesikari T, } \\
\text { et al. Live } \\
\text { attenuated } \\
\text { versus } \\
\text { inactivated } \\
\text { influenza } \\
\text { vaccine in } \\
\text { infants and } \\
\text { young children. } \\
\text { N Engl J Med } \\
\text { 2007 Feb } \\
\text { 15;356(7): } \\
\text { 685-696. }{ }^{(39)} \\
\text { (NCT00128167) }\end{array}$ & $\begin{array}{l}\text { TIV/LAIV } \\
\text { LAIV } \\
\text { FluMist }{ }^{\circledR} \\
\text { TIV } \\
\text { Fluzone }{ }^{\circledR} \\
\text { (US and Asia) } \\
\text { and Vaxigrip } \\
\text { (Europe and } \\
\text { the Middle } \\
\text { East) } \\
\text { Dose } \\
\text { - } 0.25 \text { ml (6-35 } \\
\text { months) } \\
\text { - } 0.5 m \text { ml (36-59 } \\
\text { months) } \\
\text { Schedule } \\
\text { - } 2 \text { doses (0 } \\
\text { and } 28-42 \text { days) } \\
\text { for those with } \\
\text { no previous } \\
\text { vaccination }\end{array}$ & $\begin{array}{l}\text { Randomized } \\
\text { multicentre } \\
\text { trial } \\
2004-05 \\
\text { influenza } \\
\text { season } \\
\text { US, Europe, } \\
\text { Middle East } \\
\text { and Asia }\end{array}$ & $\begin{array}{l}\text { Children } \\
6-59 \text { months } \\
\mathrm{N}=8,352 \text { (24-59 } \\
\text { months } \\
\mathrm{n}=4,384) \\
\mathrm{n}_{\text {LAIV }}=4,179 \\
(24-59 \text { months } \\
\left.\mathrm{n}_{\text {LAIV }}=2187\right) \\
\mathrm{n}_{\text {TIV }}=4,173 \\
(24-59 \text { months } \\
\left.n_{\text {TIV }}=2,197\right)\end{array}$ & 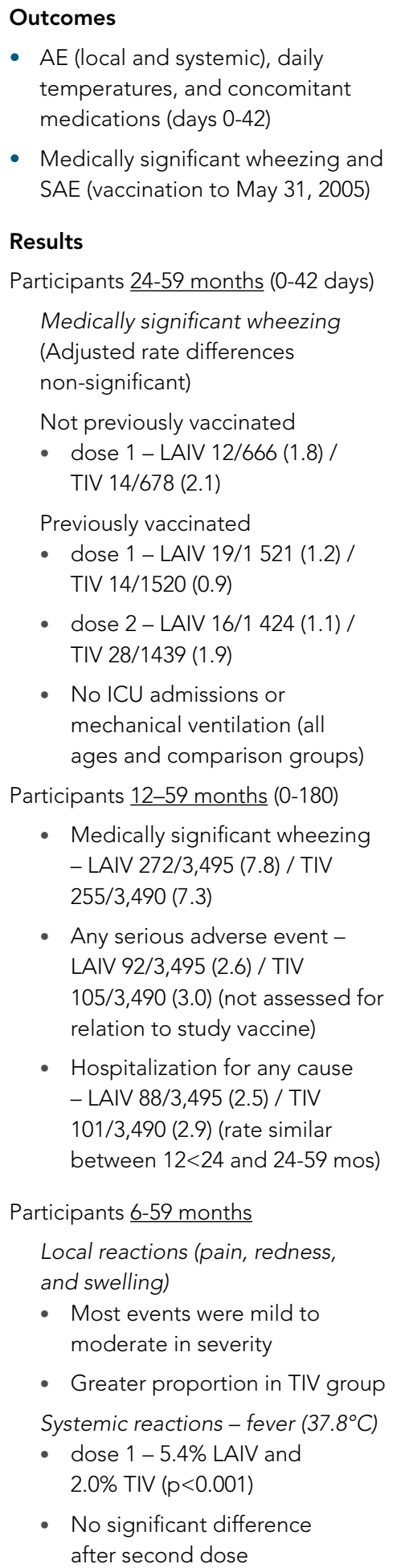 & Level I & Good \\
\hline
\end{tabular}




\begin{tabular}{|c|c|c|c|c|c|c|}
\hline \multicolumn{5}{|c|}{ EVIDENCE FOR SAFETY } & \multirow[b]{2}{*}{$\begin{array}{l}\text { Level of } \\
\text { Evidence }\end{array}$} & \multirow[b]{2}{*}{ Quality } \\
\hline Study & Vaccine & Study Design & Participants & $\begin{array}{l}\text { Summary of Key Findings } \\
\text { Using Text or Data }\end{array}$ & & \\
\hline & & & & $\begin{array}{l}\text { Absolute difference in rates of } \\
\text { hospitalization (LAIV vs TIV) } \\
\text { - Non-significant rate differences } \\
\text { between study arms for } \\
\text { comparisons by age group } \\
\text { (24-35 / 36-47 / 48-59), and } \\
\text { history of wheezing } \\
\text { - Only significant difference } \\
\text { ( } p=.039 \text { ) for children } 48-59 \\
\text { months without a history } \\
\text { of wheezing (rate greater } \\
\text { for TIV group) } \\
\text { SAE } \\
\text { - Potentially related to study } \\
\text { vaccines LAIV } n=6 \text { and TIV } n=5 \\
\text { No deaths }\end{array}$ & & \\
\hline
\end{tabular}




\begin{tabular}{|c|c|c|c|c|c|c|}
\hline \multicolumn{5}{|c|}{ EVIDENCE FOR SAFETY } & \multirow[b]{2}{*}{$\begin{array}{l}\text { Level of } \\
\text { Evidence }\end{array}$} & \multirow[b]{2}{*}{ Quality } \\
\hline Study & Vaccine & Study Design & Participants & $\begin{array}{l}\text { Summary of Key Findings } \\
\text { Using Text or Data }\end{array}$ & & \\
\hline $\begin{array}{l}\text { Neuzil KM, } \\
\text { Dupont WD, } \\
\text { Wright PF, } \\
\text { et al. Efficacy of } \\
\text { inactivated and } \\
\text { cold-adapted } \\
\text { vaccines } \\
\text { against } \\
\text { influenza A } \\
\text { infection, } 1985 \\
\text { to 1990: the } \\
\text { pediatric } \\
\text { experience. } \\
\text { Pediatr Infect } \\
\text { Dis J 2001 } \\
\text { Aug;20(8):733- } \\
740 .{ }^{(54)}\end{array}$ & $\begin{array}{l}\text { TIV/LAIV } \\
\text { Year } 1 \text { (pilot) } \\
\text { LAIV (H1N1 } \\
\text { and H3N2) and } \\
\text { inactivated B } \\
\text { vaccines } \\
\text { Bivalent } \\
\text { inactivated } \\
\text { vaccine (H1N1, } \\
\text { H3N2) } \\
\text { Year 2-5 } \\
\text { LAIV (H1N1 } \\
\text { and H3N2) } \\
\text { and inactivated } \\
\text { B vaccines } \\
\text { TIV (H1N1, } \\
\text { H3N2, B) } \\
\text { Control } \\
\text { (inactivated } \\
\text { influenza B } \\
\text { vaccine) } \\
\text { Dose - } \\
\text { <3 years } \\
\text { - Inactivated } \\
\text { vaccine } \\
0.25 \text { mL } \\
\text { 0.5 mL of a } \\
1 / 10 \text { dilution } \\
\text { of each } \\
\text { of the two } \\
\text { cold-adapt- } \\
\text { ed vaccine } \\
\text { preparations } \\
\text { as a single } \\
\text { dose }\end{array}$ & 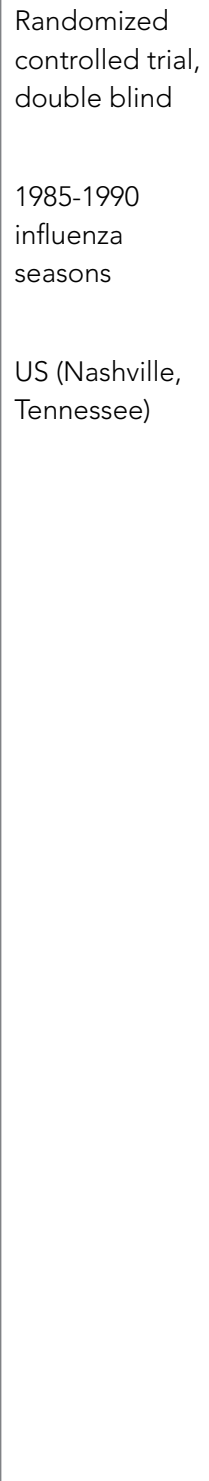 & $\begin{array}{l}\text { Children 1-16 } \\
\text { years } \\
N_{\text {doses }}=1,809 \\
\text { (791 children) } \\
1<6 \text { years } \\
\text { (doses) } \\
n_{\text {control }}=130 \\
n_{\text {LAIV-inactivated }} \\
B=144 \\
n_{\text {TIV }}=200\end{array}$ & $\begin{array}{l}\text { Outcomes } \\
\text { - reactogenicity days } 0-4 \\
\text { Results (excluding year } 1 \text { as pilot) } \\
\text { - Reaction rates (redness, induration, } \\
\text { fever, cough, coryza and sore } \\
\text { throat) were similar in all age } \\
\text { groups and across study years } \\
\text { - Reaction rates following initial and } \\
\text { repeat vaccinations were similar. } \\
\text { - 1<6 years } \\
\text { - Most frequently } \\
\text { reported reactions } \\
\text { - fever } \\
\text { - Control } 12.3 \% \\
\text { - LAIV } 13.9 \% \\
\text { - } \text { TIV } 11.5 \% \\
\text { - cough } \\
\text { - Control } 12.3 \% \\
\text { - LAIV } 12.5 \% \\
\text { - } \text { TIV } 8.5 \% \\
\text { - coryza } \\
\text { - Control } 17.7 \% \\
\text { - LAIV } 27.8 \% \\
\text { - TIV } 16.0 \% \\
\text { (tsignificant difference) } \\
\text { No SAE reported. }\end{array}$ & Level I & Good \\
\hline
\end{tabular}




\begin{tabular}{|c|c|c|c|c|c|c|}
\hline \multicolumn{5}{|c|}{ EVIDENCE FOR SAFETY } & \multirow[b]{2}{*}{$\begin{array}{l}\text { Level of } \\
\text { Evidence }\end{array}$} & \multirow[b]{2}{*}{ Quality } \\
\hline Study & Vaccine & Study Design & Participants & $\begin{array}{l}\text { Summary of Key Findings } \\
\text { Using Text or Data }\end{array}$ & & \\
\hline $\begin{array}{l}\text { Bergen R, Black } \\
\text { S, Shinefield H, } \\
\text { et al. Safety of } \\
\text { cold-adapted } \\
\text { live attenuated } \\
\text { influenza } \\
\text { vaccine in a } \\
\text { large cohort } \\
\text { of children and } \\
\text { adolescents. } \\
\text { Pediatr Infect } \\
\text { Dis J 2004 } \\
\text { Feb;23(2):138- } \\
\text { 144.(62) }\end{array}$ & $\begin{array}{l}\text { LAIV } \\
\text { Dose } \\
0.25 \mathrm{~mL} \\
\text { per nostril } \\
\text { Formulation } \\
10^{7} \mathrm{TCID}_{50} \\
\text { per strain } \\
\text { Schedule } \\
2 \text { dose } \\
\text { participants } \\
<9 y \text { rs (28-42d } \\
\text { after dose 1) }\end{array}$ & $\begin{array}{l}\text { Randomized, } \\
\text { double-blind, } \\
\text { placebo } \\
\text { controlled } \\
\text { 1999-2000 } \\
\text { Influenza } \\
\text { season }\end{array}$ & $\begin{array}{l}\mathrm{N}=9,689 \\
\mathrm{n}_{\text {LAIV }}=6,473 \\
\text { Children aged } \\
1-8 \text { years } \\
\mathrm{n}_{\text {LAIV }{ }^{\top}}= \\
3,242-3,769 \\
\mathrm{n}_{\text {placebo }}= \\
\text { 1,600-1,869 } \\
\text { Children aged } \\
18-35 \text { months } \\
n_{\text {LAIV }}=728 \\
n_{\text {placebo }}=339-369 \\
\text { Healthy } \\
\text { children aged } \\
12 \text { months } \\
\text { to } 17 \text { years } \\
\text { Excluded those } \\
\text { who received } \\
\text { TIV in } 2000 \text { or } \\
\text { any live virus } \\
\text { within } 1 \text { month } \\
\text { of study or } \\
\text { inactivated } \\
\text { vaccine within } \\
2 \text { weeks }\end{array}$ & $\begin{array}{l}\text { Outcomes } \\
\text { - } 4 \text { pre-specified diagnostic } \\
\text { categories (acute respiratory } \\
\text { tract events, systemic bacterial } \\
\text { infections, acute gastrointestinal } \\
\text { tract events, rare events potentially } \\
\text { associated with wild-type influenza) } \\
\text { - Assessment period day 0-42 post } \\
\text { vaccination completed in hospital, } \\
\text { ED, and clinic settings } \\
\text { Results } \\
\text { Significant increase in RR among } \\
\text { participants } 18-35 \text { months (all } \\
\text { settings and doses combined) } \\
\text { - Upper respiratory tract infections } \\
\text { RR } 1.30 \text { (90\% Cl 1.01, 1.67) } \\
\text { - Asthma events RR 4.06 } \\
\text { (90\% Cl 1.29-17.86) } \\
\text { - no hospitalizations required } \\
\text { - } 7 \text { of the } 16 \text { cases in LAIV group } \\
\text { had a previous clinic visit for } \\
\text { asthma } \\
\text { - Musculoskeletal pain (clinic only; } 0 \\
\text { cases in placebo group) RR NE } \\
\text { (1.30, NE) } \\
\text { to study vaccine. }\end{array}$ & Level I & Good \\
\hline
\end{tabular}




\begin{tabular}{|c|c|c|c|c|c|c|}
\hline \multicolumn{5}{|c|}{ EVIDENCE FOR SAFETY } & \multirow[b]{2}{*}{$\begin{array}{l}\text { Level of } \\
\text { Evidence }\end{array}$} & \multirow[b]{2}{*}{ Quality } \\
\hline Study & Vaccine & Study Design & Participants & $\begin{array}{l}\text { Summary of Key Findings } \\
\text { Using Text or Data }\end{array}$ & & \\
\hline $\begin{array}{l}\text { Bracco Neto H, } \\
\text { Farhat CK, } \\
\text { Tregnaghi MW, } \\
\text { et al. Efficacy } \\
\text { and safety of } \\
1 \text { and } 2 \text { doses } \\
\text { of live } \\
\text { attenuated } \\
\text { influenza } \\
\text { vaccine in } \\
\text { vaccine-naive } \\
\text { children. } \\
\text { Pediatr Infect } \\
\text { Dis J 2009 } \\
\text { May;28(5): } \\
\text { 365-371.(44) } \\
\text { (NCT00192283) }\end{array}$ & $\begin{array}{l}\text { LAIV } \\
\text { Dose } \\
0.1 \mathrm{~mL} \\
\text { per nostril } \\
\text { Formulation } \\
10^{7 \pm 0.5} \mathrm{FFU} \\
\text { per strain } \\
\text { Schedule } \\
2 \text { doses in } \\
\text { Year } 1 \text {, single } \\
\text { dose in Year } 2 \\
\text { Vaccine and } \\
\text { circulating } \\
\text { strains well } \\
\text { matched }\end{array}$ & $\begin{array}{l}\text { Randomized, } \\
\text { doubleblind, } \\
\text { placebo- } \\
\text { controlled, } \\
\text { multicentre trial } \\
2001-02 \\
\text { influenza } \\
\text { seasons } \\
\text { South Africa, } \\
\text { Brazil, } \\
\text { Argentina }\end{array}$ & $\begin{array}{l}\text { Year 1 Dose } 1 \\
n_{\text {LAII }}=2,127 \\
n_{\text {excipient placebo }}= \\
546 \\
n_{\text {saline placebo }}=527 \\
\text { Year 1 Dose } 2 \\
n_{\text {LAIV }}=964 \\
n_{\text {excipient placebo }}= \\
484 \\
n_{\text {saline placebo }}=527 \\
\text { Year 2 } \\
n_{\text {LAIV }}=1,461 \\
n_{\text {placebo }}=741 \\
\text { Healthy } \\
\text { influenza } \\
\text { vaccine-naive } \\
\text { children aged } \\
6 \text { to }<36 \\
\text { months }\end{array}$ & 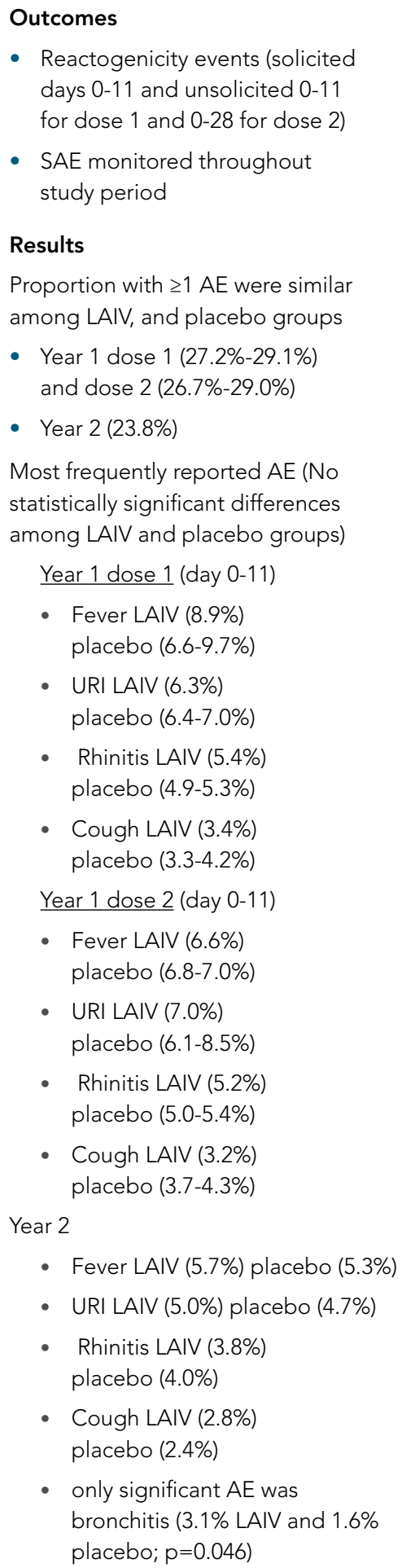 & Level I & $\begin{array}{l}\text { Good } \\
\text { Error in } \\
\text { treatment } \\
\text { allocation } \\
\text { coding } \\
\text { and } \\
\text { labelling } \\
\text { in Year } 2 \\
\text { resulted } \\
\text { in } 2 \\
\text { additional } \\
\text { treatment } \\
\text { protocols }\end{array}$ \\
\hline
\end{tabular}




\begin{tabular}{|c|c|c|c|c|c|c|}
\hline \multicolumn{5}{|c|}{ EVIDENCE FOR SAFETY } & \multirow[b]{2}{*}{$\begin{array}{l}\text { Level of } \\
\text { Evidence }\end{array}$} & \multirow[b]{2}{*}{ Quality } \\
\hline Study & Vaccine & Study Design & Participants & $\begin{array}{l}\text { Summary of Key Findings } \\
\text { Using Text or Data }\end{array}$ & & \\
\hline & & & & $\begin{array}{l}\text { SAEs in year } 1 \text { related to study } \\
\text { ( } \mathrm{n}=29 \text { ), including pneumonia, } \\
\text { bronchopneumonia, bronchiolitis } \\
\text { and bronchitis. } \\
\text { No deaths related to study product. }\end{array}$ & & \\
\hline $\begin{array}{l}\text { Breiman RF, } \\
\text { Brooks WA, } \\
\text { Goswami D, } \\
\text { et al. } \\
\text { A multinational, } \\
\text { randomized, } \\
\text { placebo-con- } \\
\text { trolled trial to } \\
\text { assess the } \\
\text { immunogen- } \\
\text { icity, safety, and } \\
\text { tolerability of } \\
\text { live attenuated } \\
\text { influenza } \\
\text { vaccine } \\
\text { coadministered } \\
\text { with oral } \\
\text { poliovirus } \\
\text { vaccine in } \\
\text { healthy young } \\
\text { children. } \\
\text { Vaccine } \\
2009 \text { Sep } \\
4 ; 27(40) \text { : } \\
5472-5479 .{ }^{(63)} \\
\text { (NCT00192491) }\end{array}$ & $\begin{array}{l}\text { LAIV } \\
\text { Dose } \\
0.2 \mathrm{ml}(0.1 \mathrm{~mL} \\
\text { per nostril; } \\
\text { Formulation } \\
10^{7 \pm 0.5} \mathrm{FFU} \\
\text { per strain } \\
\text { Schedule } \\
\text { 2nd dose } \\
\text { LAIV (or } \\
\text { placebo) given } \\
\text { 28-42 days after } \\
\text { 1st dose }\end{array}$ & $\begin{array}{l}\text { Randomized } \\
\text { controlled } \\
\text { non-inferiority } \\
\text { trial, partially } \\
\text { blinded, } \\
\text { multicentre } \\
\\
\text { Co-vaccine: } \\
\text { OPV (various } \\
\text { sources) } \\
\text { open label } \\
\text { 2002 influenza } \\
\text { season } \\
\text { Asia, South } \\
\text { America }\end{array}$ & 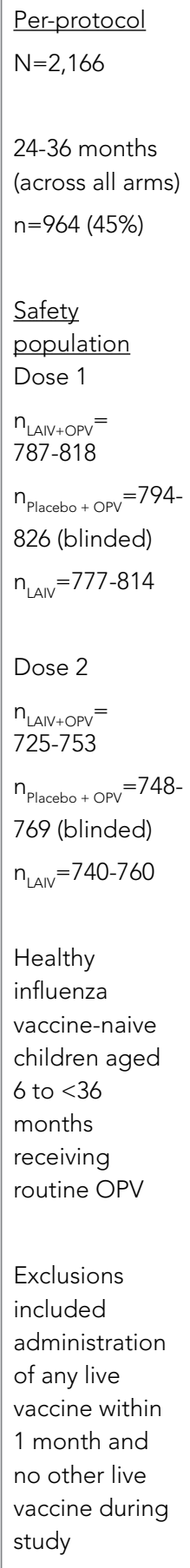 & 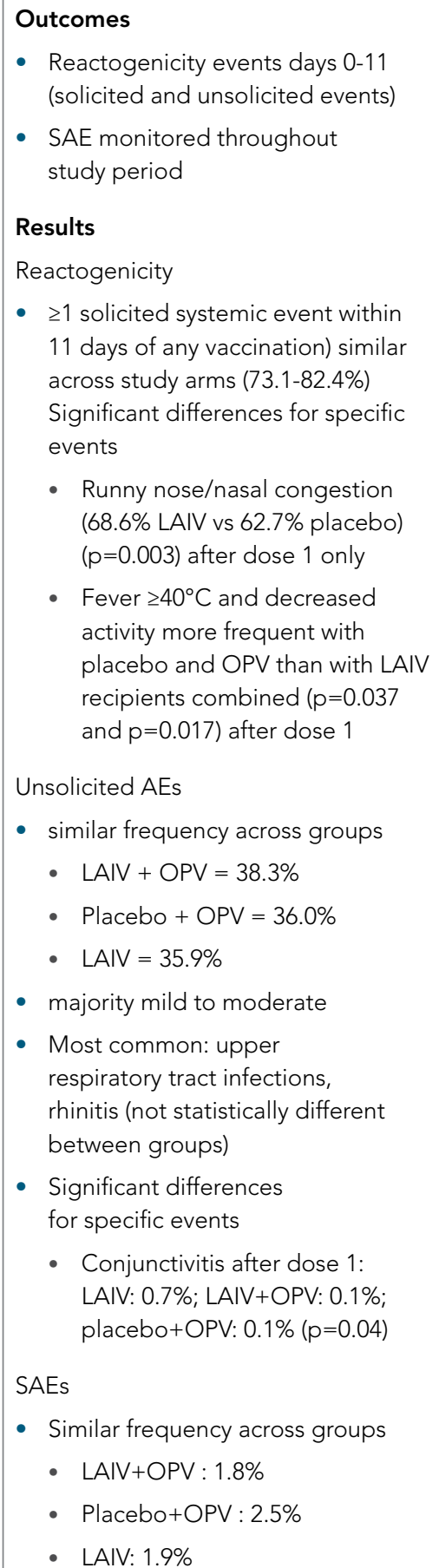 & Level I & Good \\
\hline
\end{tabular}




\begin{tabular}{|c|c|c|c|c|c|c|}
\hline \multicolumn{5}{|c|}{ EVIDENCE FOR SAFETY } & \multirow[b]{2}{*}{$\begin{array}{l}\text { Level of } \\
\text { Evidence }\end{array}$} & \multirow[b]{2}{*}{ Quality } \\
\hline Study & Vaccine & Study Design & Participants & $\begin{array}{l}\text { Summary of Key Findings } \\
\text { Using Text or Data }\end{array}$ & & \\
\hline & & & & $\begin{array}{l}\text { - } 17 \text { SAEs (possibly related to } \\
\text { study product): pneumonia }(n=4) \text {, } \\
\text { acute gastroenteritis }(n=8) \text {, } \\
\text { bronchospasm }(n=2) \text {, acute } \\
\text { tonsillitis }(n=1) \text {, febrile seizure } \\
(n=1) \text {, and acute gastritis }(n=1) \\
\text { - Receipt of LAIV not associated with } \\
\text { disproportionate incidence of SAE }\end{array}$ & & \\
\hline $\begin{array}{l}\text { Piedra PA, } \\
\text { Yan L, Kotloff K, } \\
\text { et al. Safety of } \\
\text { the trivalent, } \\
\text { cold-adapted } \\
\text { influenza } \\
\text { vaccine in } \\
\text { preschool-aged } \\
\text { children. } \\
\text { Pediatrics } 2002 \\
\text { Oct;110(4): } \\
662-672 .{ }^{(64)}\end{array}$ & $\begin{array}{l}\text { LAIV } \\
\text { Dose } \\
0.5 \mathrm{ml}(0.25 \mathrm{ml} \\
\text { per nostril) } \\
\text { Formulation } \\
10^{7} \text { TCID50 } \\
\text { per strain) } \\
\text { Schedule } \\
\text { Year } 1-1 \text { dose } \\
\text { and } 2 \text { dose } \\
\text { (60 days }+/-14) \\
\text { cohorts } \\
\text { Year } 2 \text { - } 1 \text { dose } \\
\text { as per } 1{ }^{\text {st }} \text { year } \\
\text { study arm }\end{array}$ & $\begin{array}{l}\text { RCT, double } \\
\text { blind, } \\
\text { multicentre, } \\
\text { placebo } \\
\text { controlled } \\
\text { Four seasons } \\
\text { 1996-2002 }\end{array}$ & $\begin{array}{l}\text { Year } 1 \\
n_{\text {LAIV }}=1,070 \\
n_{\text {Placebo }}=532 \\
\text { Year } 2 \\
n_{\text {LAIV }}=917 \\
n_{\text {Placebo }}=441 \\
\text { Year } 3 \\
n_{\text {LAIV }}=642 \\
\text { Year } 4 \\
n_{\text {LAIV }}=549 \\
\text { Healthy } \\
\text { children } 15 \text { to } \\
71 \text { months }\end{array}$ & 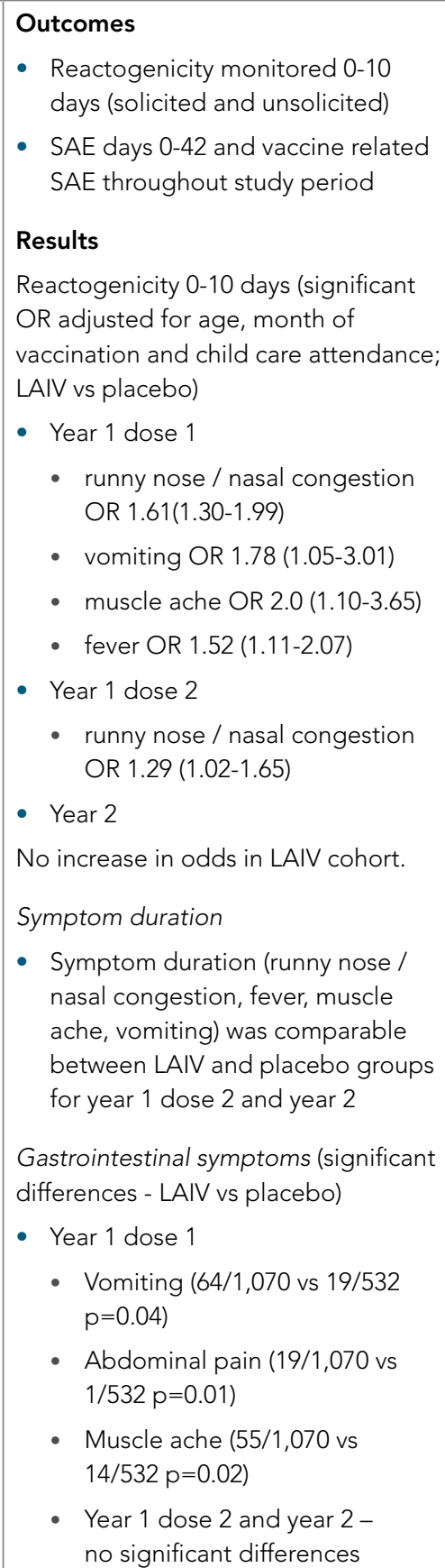 & Level I & Good \\
\hline
\end{tabular}




\begin{tabular}{|c|c|c|c|c|c|c|}
\hline \multicolumn{5}{|c|}{ EVIDENCE FOR SAFETY } & \multirow[b]{2}{*}{$\begin{array}{l}\text { Level of } \\
\text { Evidence }\end{array}$} & \multirow[b]{2}{*}{ Quality } \\
\hline Study & Vaccine & Study Design & Participants & $\begin{array}{l}\text { Summary of Key Findings } \\
\text { Using Text or Data }\end{array}$ & & \\
\hline & & & & $\begin{array}{l}\text { SAE } \\
\text { - All deemed definitely not } \\
\text { or probably not related to } \\
\text { study vaccine } \\
\text { Sequential annual doses } \\
\text { - Year } 3 \text { and } 4 \text { similar proportion } \\
\text { of symptoms compared to year } 2 \\
\text { and lower than year } 1 \text { dose } 1\end{array}$ & & \\
\hline $\begin{array}{l}\text { Piedra PA, } \\
\text { Gaglani MJ, } \\
\text { Riggs M, et al. } \\
\text { Live attenuated } \\
\text { influenza } \\
\text { vaccine, } \\
\text { trivalent, is safe } \\
\text { in healthy } \\
\text { children } 18 \\
\text { months to } 4 \\
\text { years, } 5 \text { to } 9 \\
\text { years, and } \\
10 \text { to } 18 \text { years } \\
\text { of age in a } \\
\text { community- } \\
\text { based, non- } \\
\text { randomized, } \\
\text { open-label trial. } \\
\text { Pediatrics } 2005 \\
\text { Sep;116(3): } \\
\text { e397-407.(49) }\end{array}$ & $\begin{array}{l}\text { LAIV } \\
\text { Dose } \\
0.25 \mathrm{~mL} \text { per } \\
\text { nostril } \\
\text { Formulation } \\
10^{7} \text { TCID50 } \\
\text { per strain }\end{array}$ & $\begin{array}{l}\text { Prospective, } \\
\text { multiyear open } \\
\text { label, } \\
\text { non- } \\
\text { randomized } \\
\text { trial } \\
\text { 1997-2002 } \\
\text { influenza } \\
\text { seasons } \\
\text { US }\end{array}$ & $\begin{array}{l}\text { Total } \\
\mathrm{N}=18,780 \\
\text { doses (11,096 } \\
\text { children) } \\
\text { 18mos-4 years } \\
\mathrm{n}=4529 \text { doses } \\
\text { Healthy } \\
\text { children aged } \\
\text { 1.5-18 years. } \\
\text { Children with } \\
\text { a history of } \\
\text { intermittent } \\
\text { wheezing, } \\
\text { medically } \\
\text { attended } \\
\text { acute- } \\
\text { respiratory } \\
\text { illness, } \\
\text { including } \\
\text { asthma } \\
\text { exacerbation, } \\
\text { were not } \\
\text { excluded. }\end{array}$ & $\begin{array}{l}\text { Outcomes } \\
\text { - SAE assessed over } 6 \text { week period } \\
\text { (total vaccinated) } \\
\text { - Medically attended acute } \\
\text { respiratory illness (MAARI) and } \\
\text { asthma assessed } 6 \text { week period } \\
\text { (subset of vaccinated) } \\
\text { Results } \\
\text { SAE } \\
\text { - None attributed to LAIV. } \\
\text { MAARI / Asthma } \\
\text { - } 18 \text { mos-4 years - no significant } \\
\text { increase in health care utilization } \\
\text { for MAARI, MAARI subcategories, } \\
\text { asthma on days 0-14 and only one } \\
\text { significant increase days } 15-42 \text { for } \\
\text { asthma in year } 1 \text { RR } 2.85 \text { ( } 95 \% \text { Cl, } \\
1.01-8.03 \text { ). } \\
\text { - } 18 \text { mos-4 years - no statistically } \\
\text { significant increase in health care } \\
\text { utilization for MAARI days 0-14 } \\
\text { stratified by number of doses } \\
\text { received (1-4). }\end{array}$ & Level II-3 & Good \\
\hline
\end{tabular}




\begin{tabular}{|c|c|c|c|c|c|c|}
\hline \multicolumn{5}{|c|}{ EVIDENCE FOR SAFETY } & \multirow[b]{2}{*}{$\begin{array}{l}\text { Level of } \\
\text { Evidence }\end{array}$} & \multirow[b]{2}{*}{ Quality } \\
\hline Study & Vaccine & Study Design & Participants & $\begin{array}{l}\text { Summary of Key Findings } \\
\text { Using Text or Data }\end{array}$ & & \\
\hline $\begin{array}{l}\text { Tam JS, } \\
\text { Capeding MR, } \\
\text { Lum LC, et al. } \\
\text { Efficacy and } \\
\text { safety of a live } \\
\text { attenuated, } \\
\text { cold-adapted } \\
\text { influenza } \\
\text { vaccine, } \\
\text { trivalent against } \\
\text { culture- } \\
\text { confirmed } \\
\text { influenza in } \\
\text { young children } \\
\text { in Asia. } \\
\text { Pediatr Infect } \\
\text { Dis J 2007 } \\
\text { Jul;26(7): } \\
\text { 619-628. }{ }^{(41)}\end{array}$ & $\begin{array}{l}\text { LAIV } \\
\text { Dose } \\
\text { 0.1mL per } \\
\text { nostril } \\
\text { Schedule } \\
\text { Year 1: } \\
2 \text { doses } \geq 28 \\
\text { days apart } \\
\text { Year 2: } \\
\text { Single dose } \\
\text { Formulation } \\
\text { 10 } 7 \text { TCID50 } \\
\text { per strain } \\
\text { Year } 1 \\
\text { A/New } \\
\text { Caledonia/ } \\
\text { 20/99 (H1N1), } \\
\text { A/Sydney/ } \\
\text { 05/97 (H3N2) } \\
\text { (not the } \\
\text { recommended } \\
\text { WHO strain), } \\
\text { and B/ } \\
\text { Yamanashi/ } \\
\text { 166/98 } \\
\text { Year } 2 \\
\text { A/New } \\
\text { Caledonia/ } \\
20 / 99 \text { (H1N1), } \\
\text { A/Panama/ } \\
\text { 2007/99 (H3N2), } \\
\text { and B/ } \\
\text { Yamanashi/ } \\
\text { 166/98 (not the } \\
\text { WHO recom- } \\
\text { mended strain) }\end{array}$ & $\begin{array}{l}\mathrm{RCT} \text {, double- } \\
\text { blind, placebo } \\
\text { controlled, } \\
\text { multicentre } \\
\text { 2000/01 \& } \\
2001 / 02 \\
\text { seasons }\end{array}$ & $\begin{array}{l}\frac{\text { Year 1 }}{\text { (per-protocol) }} \\
\mathrm{N}=2,764 \\
\mathrm{n}_{\text {LAIV }}=1,653 \\
\mathrm{n}_{\text {placebo }}=1,111 \\
\text { Per-protocol } \\
24-36 \text { mos. } \\
\mathrm{N}=1317 \\
\mathrm{n}_{\text {LAIV }}=782 \\
\mathrm{n}_{\text {placebo }}=535 \\
\text { Year 2 } \\
\text { (per-protocol) } \\
\mathrm{N}=2,527 \\
\mathrm{n}_{\text {LAIV/LAIV }}=771 \\
\mathrm{n}_{\text {LAIV/placebo }}=759 \\
\mathrm{n}_{\text {placebo/LAIV }}=503 \\
\mathrm{n}_{\text {placebo/placebo }}= \\
494\end{array}$ & 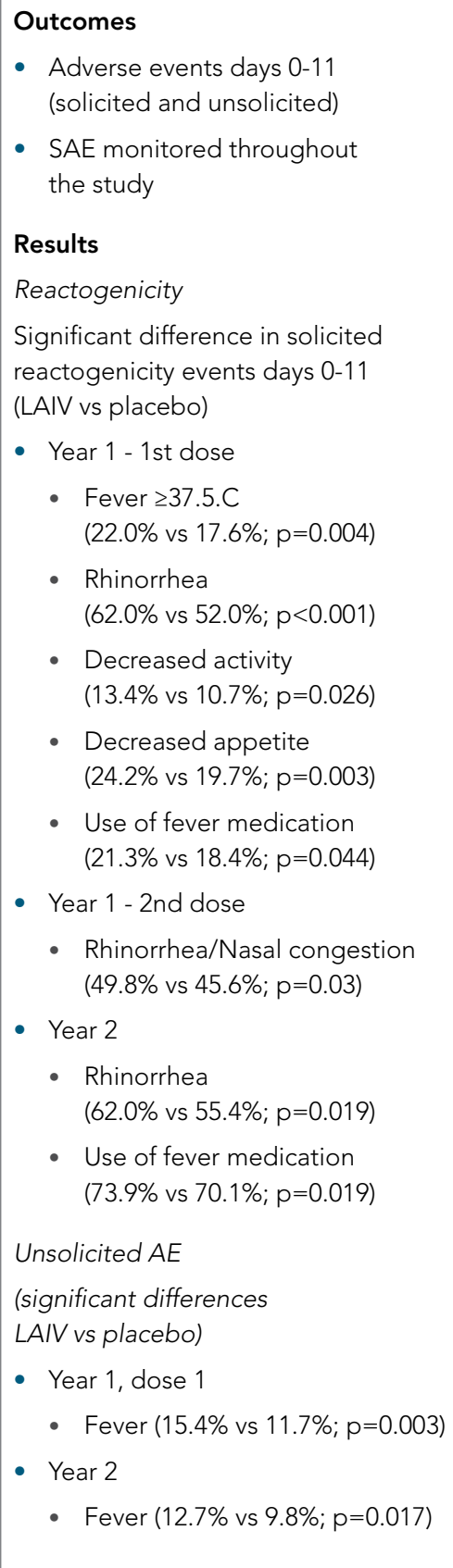 & Level I & Good \\
\hline
\end{tabular}




\begin{tabular}{|c|c|c|c|c|c|c|}
\hline \multicolumn{5}{|c|}{ EVIDENCE FOR SAFETY } & \multirow[b]{2}{*}{$\begin{array}{l}\text { Level of } \\
\text { Evidence }\end{array}$} & \multirow[b]{2}{*}{ Quality } \\
\hline Study & Vaccine & Study Design & Participants & $\begin{array}{l}\text { Summary of Key Findings } \\
\text { Using Text or Data }\end{array}$ & & \\
\hline & $\begin{array}{l}\text { B-component } \\
\text { of vaccine } \\
\text { was not well } \\
\text { matched in } \\
\text { either year. } \\
\text { ( } 29.2 \% \text { distinct } \\
\text { in year } 1,77 \% \\
\text { in year } 2 \text { ) }\end{array}$ & & & $\begin{array}{ll}\text { SAE } & \\
\text { - Uncommon and similar } \\
\text { across groups. } \\
\text { - } \text { Year } 1 \text { (LAIV vs placebo) - } \\
\text { Bronchospasm (7 vs 3), } \\
\text { Bronchitis (3 vs 2), and } \\
\text { Rhinitis ( } 3 \text { vs 0) } \\
\text { - } \text { SAE vaccine related study } \\
\text { withdrawal in Year } 1 \text { - fever x } \\
\text { 3 days in } 20 \text { month old } \\
\text { - } \quad \text { Year } 2 \text { - } 1 \text { case pneumonia } \\
\text { 6 days after vaccine (LAIV) } \\
\text { - No deaths related to study }\end{array}$ & & \\
\hline $\begin{array}{l}\text { Vesikari T, } \\
\text { Fleming DM, } \\
\text { Aristegui JF, } \\
\text { et al. Safety, } \\
\text { efficacy, and } \\
\text { effectiveness of } \\
\text { cold-adapted } \\
\text { influenza } \\
\text { vaccine-tri- } \\
\text { valent against } \\
\text { community- } \\
\text { acquired, } \\
\text { culture-con- } \\
\text { firmed influenza } \\
\text { in young } \\
\text { children } \\
\text { attending } \\
\text { day care. } \\
\text { Pediatrics 2006 } \\
\text { Dec;118(6): } \\
\text { 2298-2312.(42) }\end{array}$ & $\begin{array}{l}\text { LAIV } \\
\text { Dose } \\
0.2 \mathrm{ml}(0.1 \mathrm{~mL} \\
\text { per nostril) } \\
\text { Schedule } \\
\text { Year } 1 \text { second } \\
\text { dose } 35+/-7 \\
\text { days after 1st } \\
\text { Formulation } \\
\text { 10 7TCID50 } \\
\text { per strain } \\
\text { Year } 1 \\
\text { A/New } \\
\text { Caledonia/ } \\
\text { 20/99 (H1N1), } \\
\text { A/Sydney/ } \\
\text { 05/97 } \\
\text { (H3N2) } \\
\text { (not WHO } \\
\text { recommended } \\
\text { strain), and B/ } \\
\text { Yamanashi/ } \\
\text { 166/98 }\end{array}$ & $\begin{array}{l}\text { RCT, } \\
\text { prospective, } \\
\text { double-blind, } \\
\text { placebo } \\
\text { controlled, } \\
\text { multicentre } \\
\text { 2000-2001 \& } \\
\text { 2001-2002 } \\
\text { influenza } \\
\text { seasons } \\
\text { Belgium, } \\
\text { Finland, Israel, } \\
\text { Spain, UK }\end{array}$ & $\begin{array}{l}\text { Year } 1 \\
\text { (per-protocol) } \\
N=1,616 \\
n_{\text {LAIV }}=951 \\
n_{\text {Placebo }}=665 \\
\geq 24 \text { to } 36 \text { mos. } \\
n=844 \text { (52.2\%) } \\
n_{\text {LAIV }}=490 \\
n_{\text {Placebo }}=354 \\
\text { Year } 2 \\
\text { (per-protocol) } \\
\text { N=1,090 } \\
n_{\text {LAIV }}=640 \\
n_{\text {Placebo }}=450 \\
\geq 24 \text { to } 36 \text { mos. } \\
\text { not reported } \\
\text { Healthy } \\
\text { children aged } \\
6 \text { to }<36 \\
\text { months } \\
\text { attending day } \\
\text { care } \geq 12 \text { hours/ } \\
\text { week }\end{array}$ & $\begin{array}{l}\text { Outcomes } \\
\text { - Adverse events days } 0-11 \\
\text { (solicited and unsolicited) } \\
\text { - SAE monitored throughout } \\
\text { the study } \\
\text { Results } \\
\text { Reactogenicity events (solicited) } \\
\text { days } 0-11 \\
\text { - The only significant difference } \\
\text { occurred in Year } 1 \text { after first dose: } \\
\text { rhinorrhea (82.3\% vs } 75.4 \% \text {, } \\
\text { P=0.001). } \\
\text { AE unsolicited } \\
\text { - Similar proportions across } \\
\text { groups } \geq 1 \text { AE (LAIV } 36.4 \% \text { vs } \\
\text { placebo } 35.4 \% \text { ) } \\
\text { - Most frequently reported after } \\
\text { dose } 1 \text { (LAIV vs placebo) } \\
\text { - Fever (8.7\% vs } 7.2 \% \text { ) } \\
\text { - Rhinitis ( } 8.2 \% \text { vs } 8.0 \% \text { ) } \\
\text { - URI (4.3\% vs } 4.6 \% \text { ) } \\
\text { SAE } \\
\text { - Similar number of LRI } \\
\text { (LAIV vs placebo) } \\
\text { - Pneumonia ( } 11 \text { vs } 9 \text { ) } \\
\text { - BAEnchitis (3 vs } 1 \text { ) } \\
\text { vaccine: LAIV } n=9 \text { and placebo } n=5\end{array}$ & Level I & Good \\
\hline
\end{tabular}




\begin{tabular}{|c|c|c|c|c|c|c|}
\hline \multicolumn{5}{|c|}{ EVIDENCE FOR SAFETY } & \multirow[b]{2}{*}{$\begin{array}{l}\text { Level of } \\
\text { Evidence }\end{array}$} & \multirow[b]{2}{*}{ Quality } \\
\hline Study & Vaccine & Study Design & Participants & $\begin{array}{l}\text { Summary of Key Findings } \\
\text { Using Text or Data }\end{array}$ & & \\
\hline & $\begin{array}{l}\text { Year } 2 \\
\text { A/New } \\
\text { Caledonia/ } \\
20 / 99 \\
\text { (H1N1), A/ } \\
\text { Panama/2007/ } \\
99 \text { (H3N2), and } \\
\text { B/Victoria/504/ } \\
2000 \\
\text { Vaccine and } \\
\text { circulating } \\
\text { strains } \\
\text { well-matched } \\
\text { in year } 1 \text { but in } \\
\text { year } 2 \text { there } \\
\text { were } 2 \text { influenza } \\
\text { B strains } \\
\text { circulating that } \\
\text { were distinct } \\
\text { from vaccine } \\
\text { strain }\end{array}$ & & & $\begin{array}{l}\text { - Year } 2 \text { no statistically significant } \\
\text { differences in SAE between groups. } \\
\text { - No deaths occurred during the } \\
\text { study period. }\end{array}$ & Level I & Good \\
\hline
\end{tabular}




\section{List of Abbreviations}

\begin{tabular}{|c|c|c|c|}
\hline ACIP & $\begin{array}{l}\text { Advisory Committee on } \\
\text { Immunization Practices (US) }\end{array}$ & $\begin{array}{l}\text { ICD } \\
\text { ICU }\end{array}$ & International classification of diseases \\
\hline $\mathrm{AE}$ & Adverse event & ID & Intradermal \\
\hline AEFI & Adverse event following immunization & $\lg E$ & Immune globulin E \\
\hline Al/AN & American Indian and Alaska Natives & IgG & immune globulin G \\
\hline AMMI & $\begin{array}{l}\text { Association of Medical Microbiology } \\
\text { and Infectious Disease }\end{array}$ & ILI & Influenza-like illness \\
\hline AOM & Acute otitis media & IM & Intramuscular \\
\hline ARI & Acute respitatory infection & IMPACT & Immunization Monitoring Program, ACTive \\
\hline BMI & Body mass index & IWG & Influenza Working Group \\
\hline ca & Cold-adapted & IQR & Interquartile range \\
\hline CADTH & $\begin{array}{l}\text { Canadian Agency for Drugs and } \\
\text { Technologies in Health }\end{array}$ & LAIV & Live attenuated influenza vaccine \\
\hline CEAFISS & $\begin{array}{l}\text { Canadian Adverse Events Following } \\
\text { Immunization Surveillance System }\end{array}$ & $\begin{array}{l}\text { LOS } \\
\text { LRI }\end{array}$ & Lower respiratory infection \\
\hline CATMAT & $\begin{array}{l}\text { Committee to Advise on Tropical } \\
\text { Medicine and Travel }\end{array}$ & $\begin{array}{l}\text { LTCF } \\
\text { MAARI }\end{array}$ & Medically attended acute respiratory illness \\
\hline $\begin{array}{l}\text { CCDR } \\
\text { CDC }\end{array}$ & $\begin{array}{l}\text { Canada Communicable Disease Report } \\
\text { Centers for Disease Control and Prevention }\end{array}$ & $\begin{array}{l}\text { MAE } \\
\mathrm{mL}\end{array}$ & $\begin{array}{l}\text { Medically attended event } \\
\text { Millilitre }\end{array}$ \\
\hline $\mathrm{Cl}$ & Confidence interval & $\mathrm{MCO}$ & Managed care organization \\
\hline CIRID & $\begin{array}{l}\text { Centre for Immunization and Respiratory } \\
\text { Infectious Diseases }\end{array}$ & NA & Neuraminidase \\
\hline CNISP & $\begin{array}{l}\text { Canadian Nosocomial Infection } \\
\text { Surveillance Program }\end{array}$ & $\begin{array}{l}\mathrm{NACl} \\
\mathrm{NE}\end{array}$ & $\begin{array}{l}\text { National Advisory Committee on Immunization } \\
\text { Not estimated }\end{array}$ \\
\hline CSACI & $\begin{array}{l}\text { Canadian Society of Allergy } \\
\text { and Clinical Immunology }\end{array}$ & $\begin{array}{l}\text { NML } \\
\text { OME }\end{array}$ & $\begin{array}{l}\text { National Microbiology Laboratory } \\
\text { Otitis media with effusion }\end{array}$ \\
\hline ECDC & $\begin{array}{l}\text { European Centre for Disease } \\
\text { Prevention and Control }\end{array}$ & OPV & Oral poliovirus vaccine \\
\hline ECMO & Extracorporeal membrane oxygenation & ORS & Oculorespiratory syndrome \\
\hline FFU & Fluorescent focus units & OTC & Over the counter \\
\hline GBS & Guillain-Barré syndrome & $\begin{array}{l}\text { PCV7 } \\
\text { pH1N1 }\end{array}$ & $\begin{array}{l}\text { Heptavalent pneumococcal conjugate vaccine } \\
\text { Pandemic H1N1 } 2009\end{array}$ \\
\hline GI & Gastrointestinal & PHAC & Public Health Agency of Canada \\
\hline HBV & Hepatitis $B$ virus & $\mathrm{PICU}$ & Paediatric intensive care unit \\
\hline HCW & Health care worker & QALY & Quality-adjusted life year \\
\hline HIV & Human immunodeficiency virus & $\begin{array}{l}\mathrm{RCT} \\
\mathrm{RE}\end{array}$ & Randomized controlled trial \\
\hline
\end{tabular}




\begin{tabular}{llll}
\hline RR & Relative risk & TIV-ID & Trivalent inactivated influenza vaccine \\
RSV & Respiratory Synctal Virus & administered intradermally \\
RTI & Respiratory tract infection & Microgram \\
RT-PCR & Reverse transcription polymerase chain reaction & UIIP & Universal Influenza Immunization \\
rRT-PCR & Real-time reverse transcription & UK & United Kingdom \\
& polymerase chain reaction & URI & Upper respiratory infection \\
SAE & Serious adverse event & US & United States \\
SD & Standard deviation & VAERS & Vaccine Adverse Event Reporting System (US) \\
TESSy & The European Surveillance System & VE & Vaccine effectiveness \\
TIV & Trivalent inactivated influenza vaccine & WHO & World Health Organization
\end{tabular}




\section{References}

(1) American Academy of Pediatrics - Committee on Infectious Diseases. Prevention of influenza: recommendations for influenza immunization of children, 2007-2008. Pediatrics. 2008;121(4):e1016-31.

(2) Neuzil KM, Zhu Y, Griffin MR, et al. Burden of interpandemic influenza in children younger than 5 years: a 25-year prospective study. J Infect Dis. 2002;185(2):147-52.

(3) Neuzil KM, Mellen BG, Wright PF, et al. The effect of influenza on hospitalizations, outpatient visits, and courses of antibiotics in children. $\mathrm{N}$ Engl J Med. 2000;342(4):225-31.

(4) Izurieta HS, Thompson WW, Kramarz P, et al. Influenza and the rates of hospitalization for respiratory disease among infants and young children. N Engl J Med. 2000;342(4):232-9.

(5) Thompson WW, Shay DK, Weintraub E, et al. Influenza-associated hospitalizations in the United States. JAMA. 2004;292(11):1333-40.

(6) Poehling KA, Edwards KM, Weinberg GA, et al. The underrecognized burden of influenza in young children. N Engl J Med. 2006;355(1):31-40.

(7) Hurwitz ES, Haber M, Chang A, et al. Studies of the 1996-1997 inactivated influenza vaccine among children attending day care: immunologic response, protection against infection, and clinical effectiveness. J Infect Dis. 2000;182(4):1218-21.

(8) Louie JK, Schechter R, Honarmand S, et al. Severe pediatric influenza in California, 2003-2005: implications for immunization recommendations. Pediatrics. 2006;117(4):e610-8.

(9) Peltola V, Ziegler T, Ruuskanen O. Influenza A and $B$ virus infections in children. Clin Infect Dis. 2003;36(3):299-305.

(10) Chiu SS, Tse CY, Lau YL, et al. Influenza A infection is an important cause of febrile seizures. Pediatrics. 2001;108(4):E63.

(11) Schanzer DL, Langley JM, Tam TW. Hospitalization attributable to influenza and other viral respiratory illnesses in Canadian children. Pediatr Infect Dis J. 2006;25(9):795-800.
(12) Public Health Agency of Canada. FluWatch. 2012; Available at: http://www.phac-aspc.gc.ca/fluwatch.

(13) O'Brien MA, Uyeki TM, Shay DK, et al. Incidence of outpatient visits and hospitalizations related to influenza in infants and young children. Pediatrics. 2004;113(3 Pt 1):585-93.

(14) Bourgeois FT, Valim C, Wei JC, et al. Influenza and other respiratory virus-related emergency department visits among young children. Pediatrics. 2006;118(1):e1-8.

(15) Coffin SE, Zaoutis TE, Rosenquist AB, et al. Incidence, complications, and risk factors for prolonged stay in children hospitalized with community-acquired influenza. Pediatrics. 2007;119(4):740-8.

(16) Thompson WW, Shay DK, Weintraub E, et al. Mortality associated with influenza and respiratory syncytial virus in the United States. JAMA. 2003;289(0098-7484; 0098-7484; 2):179-86.

(17) Bhat N, Wright JG, Broder KR, et al. Influenzaassociated deaths among children in the United States, 2003-2004. N Engl J Med. 2005;353(24):2559-67.

(18) Centers for Disease Control and Prevention. Update: Influenza activity -- United States and worldwide, 2006-07 season, and composition of the 2007-08 influenza vaccine. MMWR Morb Mortal Wkly Rep. 2007;56(31):789-94.

(19) Ritzwoller DP, Bridges CB, Shetterly S, et al. Effectiveness of the 2003-2004 influenza vaccine among children 6 months to 8 years of age, with 1 vs 2 doses. Pediatrics. 2005;116(1):153-9.

(20) Eisenberg KW, Szilagyi PG, Fairbrother G, et al. Vaccine effectiveness against laboratory-confirmed influenza in children 6 to 59 months of age during the 2003-2004 and 2004-2005 influenza seasons. Pediatrics. 2008;122(5):911-9.

(21) Joshi AY, lyer VN, St Sauver JL, et al. Effectiveness of inactivated influenza vaccine in children less than 5 years of age over multiple influenza seasons: a case-control study. Vaccine. 2009;27(33):4457-61. 
(22) Kelly H, Jacoby P, Dixon GA, et al. Vaccine effectiveness against laboratory-confirmed influenza in healthy young children: A case-control study. Pediatr Infect Dis J. 2011;30(2):107-11.

(23) Staat MA, Griffin MR, Donauer S, et al. Vaccine effectiveness for laboratory-confirmed influenza in children 6-59 months of age, 2005-2007. Vaccine. 2011;29(48):9005-11.

(24) Shuler CM, Iwamoto M, Bridges CB, et al. Vaccine effectiveness against medically attended, laboratoryconfirmed influenza among children aged 6 to 59 months, 2003-2004. Pediatrics. 2007;119(3):e587-95.

(25) Belongia EA, Kieke BA, Donahue JG, et al. Effectiveness of inactivated influenza vaccines varied substantially with antigenic match from the 2004-2005 season to the 2006-2007 season. J Infect Dis. 2009;199(2):159-67.

(26) Heinonen S, Silvennoinen $\mathrm{H}$, Lehtinen $\mathrm{P}$, et al. Effectiveness of inactivated influenza vaccine in children aged 9 months to 3 years: an observational cohort study. Lancet Infect Dis. 2011;11(1):23-9.

(27) Dixon GA, Moore HC, Kelly H, et al. Lessons from the first year of the WAIVE study investigating the protective effect of influenza vaccine against laboratory-confirmed influenza in hospitalised children aged 6-59 months. Influenza other respi viruses. 2010;4(4):231-4.

(28) Szilagyi PG, Fairbrother G, Griffin MR, et al. Influenza vaccine effectiveness among children 6 to 59 months of age during 2 influenza seasons: a case-cohort study. Arch Pediatr Adolesc Med. 2008;162(10):943-51.

(29) Katayose M, Hosoya M, Haneda T, et al. The effectiveness of trivalent inactivated influenza vaccine in children over six consecutive influenza seasons. Vaccine. 2011;29(9):1844-9.

(30) Maeda T, Shintani Y, Miyamoto H, et al. Prophylactic effect of inactivated influenza vaccine on young children. Pediatr Int. 2002;44(1):43-6.

(31) Ochiai H, Fujieda M, Ohfuji S, et al. Inactivated influenza vaccine effectiveness against influenza-like illness among young children in Japan--with special reference to minimizing outcome misclassification. Vaccine. 2009;27(50):7031-5.
(32) Ghendon YZ, Kaira AN, Elshina GA. The effect of mass influenza immunization in children on the morbidity of the unvaccinated elderly. Epidemiol Infect. 2006;134(1):71-8.

(33) Fujieda M, Maeda A, Kondo K, et al. Influenza vaccine effectiveness and confounding factors among young children. Vaccine. 2008;26(50):6481-5.

(34) Fujieda M, Maeda A, Kondo K, et al. Inactivated influenza vaccine effectiveness in children under 6 years of age during the 2002-2003 season. Vaccine. 2006;24(7):957-63.

(35) Hoen AG, Buckeridge DL, Charland KM, et al. Effect of expanded US recommendations for seasonal influenza vaccination: comparison of two pediatric emergency departments in the United States and Canada. CMAJ. 2011;183(13):E1025-32.

(36) National Advisory Committee on Immunization. Recommendations on the use of live, attenuated influenza vaccine (FluMist ${ }^{\circledR}$ ): Supplemental Statement on Seasonal Influenza Vaccine 2011-2012. CCDR. 2011;37(ACS-7):March 62012.

(37) Ashkenazi S, Vertruyen A, Aristegui J, et al. Superior relative efficacy of live attenuated influenza vaccine compared with inactivated influenza vaccine in young children with recurrent respiratory tract infections. Pediatr Infect Dis J. 2006;25(10):870-9.

(38) Ambrose CS, Levin MJ, Belshe RB. The relative efficacy of trivalent live attenuated and inactivated influenza vaccines in children and adults. Influenza other respi viruses. 2011;5(2):67-75.

(39) Belshe RB, Edwards KM, Vesikari T, et al. Live attenuated versus inactivated influenza vaccine in infants and young children. N Engl J Med. 2007;356(7):685-96.

(40) Belshe RB, Toback SL, Yi T, et al. Efficacy of live attenuated influenza vaccine in children 6 months to 17 years of age. Influenza other respi viruses. 2010;4(3):141-5.

(41) Tam JS, Capeding MR, Lum LC, et al. Efficacy and safety of a live attenuated, cold-adapted influenza vaccine, trivalent against culture-confirmed influenza in young children in Asia. Pediatr Infect Dis J. 2007;26(7):619-28. 
(42) Vesikari T, Fleming DM, Aristegui JF, et al. Safety, efficacy, and effectiveness of cold-adapted influenza vaccine-trivalent against community-acquired, culture-confirmed influenza in young children attending day care. Pediatrics. 2006;118(6):2298-312.

(43) Gaglani MJ, Piedra PA, Herschler GB, et al. Direct and total effectiveness of the intranasal, live-attenuated, trivalent cold-adapted influenza virus vaccine against the 2000-2001 influenza $A(H 1 N 1)$ and B epidemic in healthy children. Arch Pediatr Adolesc Med. 2004;158(1):65-73.

(44) Bracco Neto H, Farhat CK, Tregnaghi MW, et al. Efficacy and safety of 1 and 2 doses of live attenuated influenza vaccine in vaccine-naive children. Pediatr Infect Dis J. 2009;28(5):365-71.

(45) Rhorer J, Ambrose CS, Dickinson S, et al. Efficacy of live attenuated influenza vaccine in children: A meta-analysis of nine randomized clinical trials. Vaccine. 2009;27(7):1101-10.

(46) Ozgur SK, Beyazova U, Kemaloglu YK, et al. Effectiveness of inactivated influenza vaccine for prevention of otitis media in children. Pediatr Infect Dis J. 2006;25(5):401-4.

(47) Hurwitz ES, Haber M, Chang A, et al. Effectiveness of influenza vaccination of day care children in reducing influenza-related morbidity among household contacts. JAMA. 2000;284(13):1677-82.

(48) Principi N, Esposito S, Marchisio P, et al. Socioeconomic impact of influenza on healthy children and their families. Pediatr Infect Dis J. 2003;22(10 Suppl):S207-10.

(49) Piedra PA, Gaglani MJ, Kozinetz CA, et al. Herd immunity in adults against influenza-related illnesses with use of the trivalent-live attenuated influenza vaccine (CAIV-T) in children. Vaccine. 2005;23(13):1540-8.

(50) Loeb M, Russell ML, Moss L, et al. Effect of influenza vaccination of children on infection rates in Hutterite communities: a randomized trial. JAMA. 2010;303(10):943-50.

(51) Pitman RJ, White LJ, Sculpher M. Estimating the clinical impact of introducing paediatric influenza vaccination in England and Wales. Vaccine. 2012;30(6):1208-24.
(52) Skowronski DM, Hottes TS, De Serres G, et al. Influenza B/Victoria antigen induces strong recall of $\mathrm{B} /$ Yamagata but lower B/Victoria response in children primed with two doses of B/Yamagata. Pediatr Infect Dis J. 2011;30(10):833-9.

(53) Zeman AM, Holmes TH, Stamatis S, et al. Humoral and cellular immune responses in children given annual immunization with trivalent inactivated influenza vaccine. Pediatr Infect Dis J. 2007;26(2):107-15.

(54) Neuzil KM, Dupont WD, Wright PF, et al. Efficacy of inactivated and cold-adapted vaccines against influenza A infection, 1985 to 1990: the pediatric experience. Pediatr Infect Dis J. 2001;20(8):733-40.

(55) Ambrose CS, Wu X, Belshe RB. The efficacy of live attenuated and inactivated influenza vaccines in children as a function of time postvaccination. Pediatr Infect Dis J. 2010;29(9):806-11.

(56) Gruber WC, Taber LH, Glezen WP, et al. Live attenuated and inactivated influenza vaccine in school-age children. Am J Dis Child. 1990;144(5):595-600.

(57) Baxter R, Jeanfreau R, Block SL, et al. A Phase III evaluation of immunogenicity and safety of two trivalent inactivated seasonal influenza vaccines in US children. Pediatr Infect Dis J. 2010;29(10):924-30.

(58) Jansen AG, Sanders EA, Smulders S, et al. Adverse reactions to simultaneous influenza and pneumococcal conjugate vaccinations in children: randomized double-blind controlled trial. Pediatr Allergy Immunol. 2008;19(6):552-8.

(59) Glanz JM, Newcomer SR, Hambidge SJ, et al. Safety of trivalent inactivated influenza vaccine in children aged 24 to 59 months in the vaccine safety datalink. Arch Pediatr Adolesc Med. 2011;165(8):749-55.

(60) Muhammad RD, Haber P, Broder KR, et al. Adverse events following trivalent inactivated influenza vaccination in children: Analysis of the vaccine adverse event reporting system. Pediatr Infect Dis J. 2011;30(1):e1-8.

(61) Public Health Agency of Canada. Canadian Adverse Event Following Immunization Surveillance System. 2012; Available at: http://www.phac-aspc.gc.ca/im/ vs-sv/caefiss-eng.php. 
(62) Bergen R, Black S, Shinefield H, et al. Safety of cold-adapted live attenuated influenza vaccine in a large cohort of children and adolescents. Pediatr Infect Dis J. 2004;23(2):138-44.

(63) Breiman RF, Brooks WA, Goswami D, et al. A multinational, randomized, placebo-controlled trial to assess the immunogenicity, safety, and tolerability of live attenuated influenza vaccine coadministered with oral poliovirus vaccine in healthy young children. Vaccine. 2009;27(40):5472-9.

(64) Piedra PA, Yan L, Kotloff K, et al. Safety of the trivalent, cold-adapted influenza vaccine in preschool-aged children. Pediatrics. 2002;110(4):662-72.

(65) Mallory RM, Yi T, Ambrose CS. Shedding of Ann Arbor strain live attenuated influenza vaccine virus in children 6-59 months of age. Vaccine. 2011;29(26):4322-7.
(66) Zangwill KM, Droge J, Mendelman P, et al. Prospective, randomized, placebo-controlled evaluation of the safety and immunogenicity of three lots of intranasal trivalent influenza vaccine among young children. Pediatr Infect Dis J. 2001; 20(8):740-6.

(67) Mendelman PM, Cordova J, Cho I. Safety, efficacy and effectiveness of the influenza virus vaccine, trivalent, types $A$ and $B$, live, cold-adapted (CAIV-T) in healthy children and healthy adults. Vaccine. 2001;19(17-19):2221-6.

(68) Haber P, Arana J, Walton K. Safety of live attenuated influenza vaccine in children aged 24-59 months, Vaccine Adverse Event Reporting System (VAERS), 2007-2009. 49th Interscience conference on antimicrobial agents and chemotherapy, San Francisco, CA. September 12-14, 2009. Abstract GI-872. 2009 